Shadow Economies and Corruption all over the World:

What do we really know?

by

Friedrich SCHNEIDER ${ }^{*}$

Working Paper No. 0617

September 2006

Johannes Kepler University of Linz Department of Economics Altenberger Strasse 69 A-4040 Linz - Auhof, Austria www.econ.jku.at 


\title{
Shadow Economies and Corruption all over the World: What do we really know?*)
}

\author{
by
}

Friedrich Schneider**)

\begin{abstract}
:
Estimations of the size and development of the shadow economy for 145 countries, including developing, transition and highly developed OECD economies over the period 1999 to 2003 are presented. The average size of the shadow economy (as a percent of "official" GDP) in 2002/03 in 96 developing countries is $38.7 \%$, in 25 transition countries $40.1 \%$, in 21 OECD countries $16.3 \%$ and in 3 Communist countries $22.3 \%$. An increased burden of taxation and social security contributions, combined with a labor market regulation are the driving forces of the shadow economy. Furthermore, the results show that the shadow economy reduces corruption in high income countries, but increases corruption in low income countries. Finally, the various estimation methods are discussed and critically evaluated.
\end{abstract}

JEL-class.: O17, O5, D78, H2, H11, H26.

Keywords: shadow economy of 145 countries, tax burden, tax moral, quality of state institutions, regulation, DYMIMIC and other estimation methods

*) Paper to be presented at the $8^{\text {th }}$ INFER Annual Conference, University College Cork, Cork, Ireland, 22-24 September, 2006.

**) Professor of Economics, Dr. DDr.h.c. Friedrich Schneider, Department of Economics, Johannes Kepler University of Linz, A-4040 Linz-Auhof, Austria. Phone: 0043-732-24688210, Fax: -8209. E-mail: friedrich.schneider@jku.at, http://www.econ.jku.at/Schneider. 


\section{Contents}

1 Introduction ..........................................................................................................................3

2 Some Theoretical Considerations about the Shadow Economy .....................................4

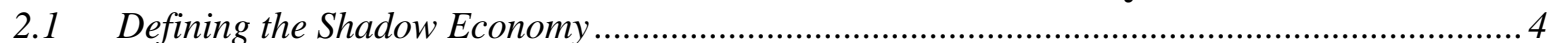

2.2 The Main Causes of Determining the Shadow Economy ..................................................... 6

2.2.1 Tax and Social Security Contribution Burdens ……….............................................................. 6

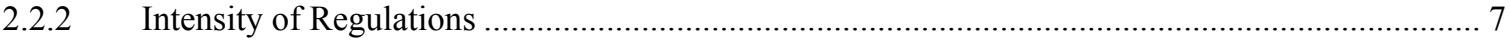

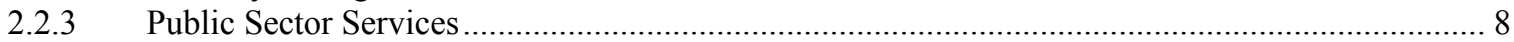

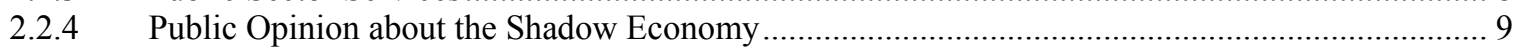

2.2.5 Summary of the Main Causes of the Shadow Economy .............................................................. 13

3 The Size of the Shadow Economies for 145 Countries.....................................................14

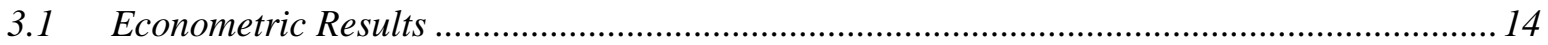

3.2 The Size of the Shadow Economies for 145 Countries for 1999/2000, 2001/2002 and

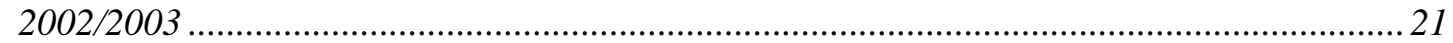

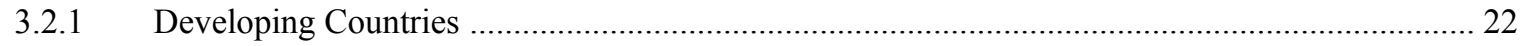

3.2.2 Transition Countries.............................................................................................. 25

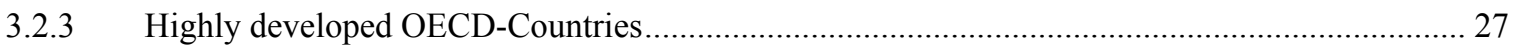

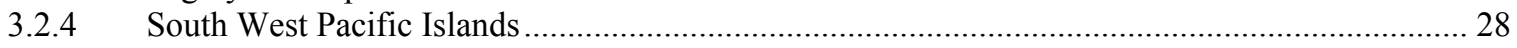

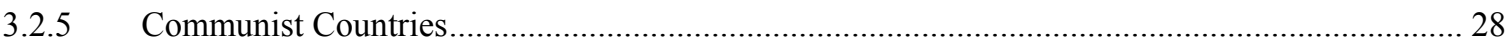

4 Corruption and the Shadow Economy: Substitutes or Compliments? ........................29

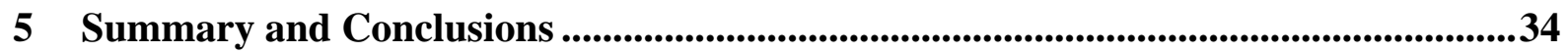

6 Appendix 1: Methods to Estimate the Size of the Shadow Economy …......................36

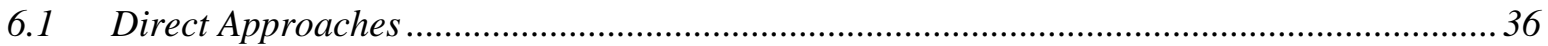

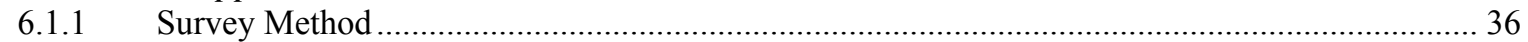

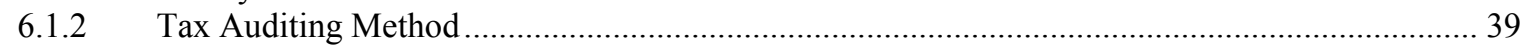

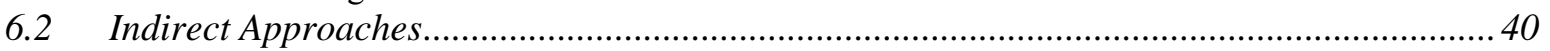

6.2.1 The Discrepancy between National Expenditure and Income Statistics .......................................... 40

6.2.2 The Discrepancy between the Official and Actual Labor Force ................................................. 41

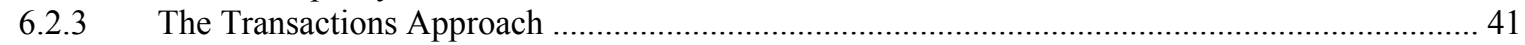

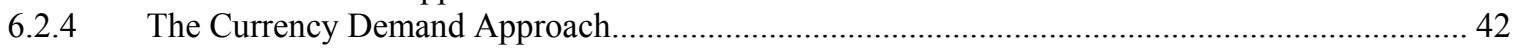

6.2.5 The Physical Input (Electricity Consumption) Method................................................................. 45

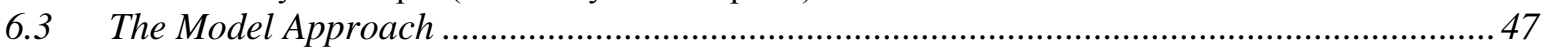

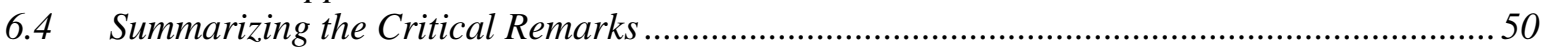

6.5 The Size and Development of the Shadow Economies of 145 Countries over 1999/2000 to

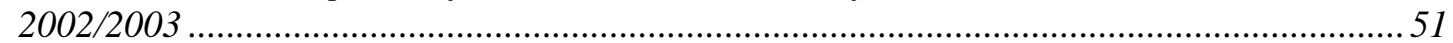

7 Appendix 2: Definition of the variables and data sources ..........................................55

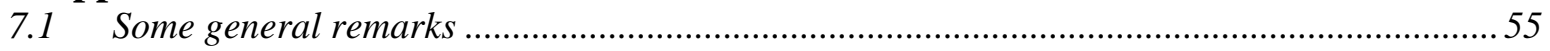

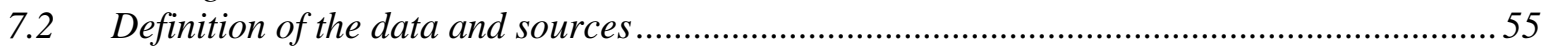

8 Appendix 3: Descriptive Statistics of the variables ...............................................58

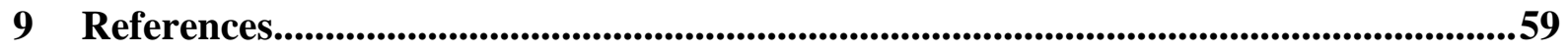




\section{Introduction}

As corruption and shadow economic activities are a fact of life around the world, most societies attempt to control these activities through various measures like punishment, prosecution, economic growth or education. To gather information about the extend of corruption and the shadow economy and it's relationship or who is engaged in corrupt and/or underground activities, the frequencies with which these activities are occurring and the magnitude of them, is crucial for making effective and efficient decisions regarding the allocations of a country's resources in this area. Unfortunately, it is very difficult to get accurate information about the relationship between corruption and shadow economy activities on the goods and labor market, because all individuals engaged in these activities wish not to be identified. Hence, doing research in these two areas can be considered as a scientific passion for knowing the unknown.

Although quite a large literature ${ }^{1)}$ on single aspects of the hidden or shadow economy exists and a comprehensive survey has been written by Schneider (the author of this paper) and Enste (2000), the subject is still quite controversial ${ }^{2)}$ as there are disagreements about the definition of shadow economy activities, the estimation procedures and the use of their estimates in economic analysis and policy aspects. ${ }^{3)}$ Nevertheless around the world, there are some indications for an increase of the shadow economy but little is known about the development and the size of the shadow economies in transition, development and developed countries over the latest period 1999/2000 to 2002/2003.

Hence, the goal of this paper is threefold: to undertake the challenging task to estimate the shadow economy for 145 countries all over the world to provide some insights about the main causes of the shadow economy and to explore the relationship between shadow and corruption. In section 2 an attempt is made to define the shadow economy and some

\footnotetext{
1) The literature about the „shadow“, „underground“, ,informal“, „,second“, “cash-“ or ,parallel“, economy is increasing. Various topics, on how to measure it, its causes, its effect on the official economy are analyzed. See for example, survey type publications by Frey and Pommerehne (1984); Thomas (1992); Loayza (1996); Pozo (1996); Lippert and Walker (1997); Schneider (1994a, 1994b, 1997, 1998a); Johnson, Kaufmann, and Shleifer (1997), Johnson, Kaufmann and Zoido-Lobatón (1998a, 1998b); Belev (2003); Gerxhani (2003) and Pedersen (2003). For an overall survey of the global evidence of the size of the shadow economy see Schneider and Enste (2000, 2002), Schneider (2003, 2005) and Alm, Martinez and Schneider (2004), and Kazemier (20025a)

2) Compare e.g. in the Economic Journal, vol. 109, no. 456, June 1999 the feature "controversy: on the hidden economy".

3) Compare the different opinions of Tanzi (1999), Thomas (1999), Giles (1999a,b) and Pedersen (2003), and Janisch and Brümmerhoff (2005).
} 
theoretical considerations about the reasons why the shadow is increasing are undertaken. Section 3 presents the econometric estimation results and the calculation of the size of the shadow economy over 145 countries over the period 1999/2000 to 2002/03. In section 4 two hypotheses about the relationship between the shadow and corruption are derived and some empirical results are shown. Finally, in section 5 a summary is given and some policy conclusions are drawn. Finally in the three appendices (chapter 6, 7 and 8) the various methods to estimate the shadow economy are presented and critically evaluated, as well as a definition of the variables and data sources are given and the descriptive statistics of the variables are shown.

\section{Some Theoretical Considerations about the Shadow Economy}

\subsection{Defining the Shadow Economy ${ }^{4)}$}

Most authors trying to measure the shadow economy face the difficulty of how to define it. One commonly used working definition is all currently unregistered economic activities that contribute to the officially calculated (or observed) Gross National Product. ${ }^{5)}$ Smith (1994, p. 18) defines it as „,market-based production of goods and services, whether legal or illegal that escapes detection in the official estimates of GDP." Or to put it in another way, one of the broadest definitions of it, includes..."those economic activities and the income derived from them that circumvent or other wise government regulation, taxation or observation". ${ }^{\text {) }}$ As these definitions still leave open a lot of questions, table 2.1 is helpful for developing a better feeling for what could be a reasonable consensus definition of the underground (or shadow) economy.

From table 2.1, it becomes clear that a broad definition of the shadow economy includes unreported income from the production of legal goods and services, either from monetary or

\footnotetext{
${ }^{4}$ This paper focuses on the size and development of the shadow economy for countries and does not show any disaggregated values for specific regions. Lately some first studies were undertaken to measure the size of the shadow economy as well as the "grey" or "shadow" labor force for urban regions or states (e.g. California). Compare e.g. Marcelli, Pastor and Joassart (1999), Marcelli (2004), Chen (2004), Williams (2004a, b, 2005a, b, 2006), Williams and Windebank (1999, 2001a, b), Flaming, Haydamack, and Jossart (2005) and Alderslade, Talmage and Freeman (2006), and Brueck, Haisten-DeNew and Zimmermann (2006).

5) This definition is used for example, by Feige (1989, 1994), Schneider (1994a, 2003, 2005) and Frey and Pommerehne (1984). Do-it-yourself activities are not included. For estimates of the shadow economy and the doit-yourself activities for Germany see Karmann (1986, 1990).

6) This definition is taken from Del'Anno (2003), Del'Anno and Schneider (2004) and Feige (1989); see also Thomas (1999), Fleming, Roman and Farrell (2000).
} 
barter transactions - and so includes all economic activities that would generally be taxable were they reported to the state (tax) authorities. In this paper the following more narrow definition of the shadow economy is used: ${ }^{7)}$ The shadow economy includes all market-based legal production of goods and services that are deliberately concealed from public authorities for the following reasons:

(1) to avoid payment of income, value added or other taxes,

(2) to avoid payment of social security contributions,

(3) to avoid having to meet certain legal labor market standards, such as minimum wages, maximum working hours, safety standards, etc., and

(4) to avoid complying with certain administrative procedures, such as completing statistical questionnaires or other administrative forms.

Hence, in this paper, I will not deal with typical underground, economic (classical crime) activities, which are all illegal actions that fits the characteristics of classical crimes like burglary, robbery, drug dealing, etc. I also include not the informal household economy which consists of all household services and production. Also this paper does not focus on tax evasion or tax compliance, because it would get to long, and moreover tax evasion is a different subject, where already a lot of research has been underway. ${ }^{8)}$

\footnotetext{
7) Compare also the excellent discussion of the definition of the shadow economy in Pedersen (2003, pp.13-19) and Kazemier (2005a) who use a similar one.

${ }^{8)}$ Compare, e.g. the survey of Andreoni, Erard and Feinstein (1998) and the paper by Kirchler, Maciejovsky and Schneider (2002).
} 
Table 2.1: A Taxonomy of Types of Underground Economic Activities ${ }^{1)}$

\begin{tabular}{|c|c|c|c|c|}
\hline Type of Activity & \multicolumn{2}{|c|}{ Monetary Transactions } & \multicolumn{2}{|c|}{ Non Monetary Transactions } \\
\hline $\begin{array}{l}\text { Illegal } \\
\text { Activities }\end{array}$ & \multicolumn{2}{|c|}{$\begin{array}{l}\text { Trade with stolen goods; drug dealing } \\
\text { and manufacturing; prostitution; } \\
\text { gambling; smuggling; fraud; etc. }\end{array}$} & \multicolumn{2}{|c|}{$\begin{array}{l}\text { Barter of drugs, stolen goods, } \\
\text { smuggling etc. Produce or growing } \\
\text { drugs for own use. Theft for own } \\
\text { use. }\end{array}$} \\
\hline & Tax Evasion & $\begin{array}{l}\text { Tax } \\
\text { Avoidance }\end{array}$ & Tax Evasion & Tax Avoidance \\
\hline $\begin{array}{l}\text { Legal } \\
\text { Activities }\end{array}$ & $\begin{array}{l}\text { Unreported income } \\
\text { from self- } \\
\text { employment; Wages, } \\
\text { salaries and assets } \\
\text { from unreported work } \\
\text { related to legal } \\
\text { services and goods }\end{array}$ & $\begin{array}{l}\text { Employee } \\
\text { discounts, } \\
\text { fringe benefits }\end{array}$ & $\begin{array}{l}\text { Barter of legal } \\
\text { services and } \\
\text { goods }\end{array}$ & $\begin{array}{l}\text { All do-it-yourself } \\
\text { work and } \\
\text { neighbor help }\end{array}$ \\
\hline
\end{tabular}

${ }^{1)}$ Structure of the table is taken from Lippert and Walker (1997, p. 5) with additional remarks.

\subsection{The Main Causes of Determining the Shadow Economy}

\subsubsection{Tax and Social Security Contribution Burdens}

In almost all studies ${ }^{9)}$ it has been found out, that the tax and social security contribution burdens are one of the main causes for the existence of the shadow economy. Since taxes affect labor-leisure choices, and also stimulate labor supply in the shadow economy, the distortion of the overall tax burden is a major concern of economists. The bigger the difference between the total cost of labor in the official economy and the after-tax earnings (from work), the greater is the incentive to avoid this difference and to work in the shadow economy. Since this difference depends broadly on the social security burden/payments and the overall tax burden, they are key features of the existence and the increase of the shadow economy.

But even major tax reforms with major tax rate deductions will not lead to a substantial decrease of the shadow economy. ${ }^{10)}$ Such reforms will only be able to stabilize the size of the shadow economy and avoid a further increase. Social networks and personal relationships, the high profit from irregular activities and associated investments in real and human capital are strong ties which prevent people from transferring to the official economy. For Canada, Spiro

\footnotetext{
9) See Thomas (1992); Lippert and Walker (1997); Schneider (1994a,b, 1997, 1998a,b, 2000, 2003b, 2005); Johnson, Kaufmann, and Zoido-Lobatón (1998a,1998b); Tanzi (1999); Giles (1999a); Mummert and Schneider (2001); Giles and Tedds (2002) and Dell'Anno (2003), just to quote a few recent ones.

10) See Schneider (1994b, 1998b) for a similar result of the effects of a major tax reform in Austria on the shadow economy. Schneider shows that a major reduction in the direct tax burden did not lead to a major reduction in the shadow economy. Because legal tax avoidance was abolished and other factors, like regulations, were not changed; hence for a considerable part of the tax payers the actual tax and regulation burden remained
} 
(1993) found similar reactions of people facing an increase in indirect taxes (VAT, GST). This fact makes it even more difficult for politicians to carry out major reforms because they may not gain a lot from them.

Empirical results of the influence of the tax burden on the shadow economy is provided in the studies of Schneider (1994b, 2000, 2004, 2005) and Johnson, Kaufmann and Zoido-Lobatón (1998a, 1998b); they all found statistically significant evidence for the influence of taxation on the shadow economy. This strong influence of indirect and direct taxation on the shadow economy is further demonstrated by discussing empirical results in the case of Austria and the Scandinavian countries. For Austria the driving force for the shadow economy activities is the direct tax burden (including social security payments), it has the biggest influence, followed by the intensity of regulation and complexity of the tax system. A similar result has been achieved by Schneider (1986) for the Scandinavian countries (Denmark, Norway and Sweden). In all three countries various tax variables (average direct tax rate, average total tax rate (indirect and direct tax rate)) and marginal tax rates have the expected positive sign (on currency demand) and are highly statistically significant. These findings are supported by studies of Kirchgaessner $(1983,1984)$ for Germany and by Klovland (1984) for Norway and Sweden, too.

In this study an attempt will be made to investigate the influence of the direct and indirect tax burden as well as the social security payments on the shadow economy for developing, transition and highly developed countries. Hence, for the first time this influence is investigated for developing, transition and highly developed countries for the same time period and using the same estimation technique.

\subsubsection{Intensity of Regulations}

The increase of the intensity of regulations (often measured in the numbers of laws and regulations, like licenses requirements) is another important factor, which reduces the freedom (of choice) for individuals engaged in the official economy. ${ }^{11)}$ One can think of labor market regulations, trade barriers, and labor restrictions for foreigners. Johnson, Kaufmann, and Zoido-Lobatón (1998b) find an overall significant empirical evidence of the influence of (labor) regulations on the shadow economy, the impact is clearly described and theoretically derived in other studies, e.g. for Germany (Deregulation Commission 1990/91). Regulations

\footnotetext{
unchanged.

${ }^{11)}$ See for a (social) psychological, theoretical foundation of this feature, Brehm $(1966,1972)$, and for a (first) application to the shadow economy, Pelzmann (1988).
} 
lead to a substantial increase in labor costs in the official economy. But since most of these costs can be shifted on the employees, these costs provide another incentive to work in the shadow economy, where they can be avoided. Empirical evidence supporting the model of Johnson, Kaufmann, and Shleifer (1997), which predicts, inter alia, that countries with more general regulation of their economies tend to have a higher share of the unofficial economy in total GDP, is found in their empirical analysis. A one-point increase of the regulation index (ranging from 1 to 5 , with $5=$ the most regulation in a country), ceteris paribus, is associated with an 8.1 percentage point increase in the share of the shadow economy, when controlled for GDP per capita (Johnson et. al. (1998b), p. 18). They conclude that it is the enforcement of regulation, which is the key factor for the burden levied on firms and individuals, and not the overall extent of regulation - mostly not enforced - which drive firms into the shadow economy. Friedman, Johnson, Kaufmann and Zoido-Lobaton (1999) reach a similar result. In their study every available measure of regulation is significantly correlated with the share of the unofficial economy and the sign of the relationship is unambiguous: more regulation is correlated with a larger shadow economy. A one point increase in an index of regulation (ranging from 1-5) is associated with a $10 \%$ increase in the shadow economy for 76 developing, transition and developed countries.

These findings demonstrate that governments should put more emphasis on improving enforcement of laws and regulations, rather than increasing their number. Some governments, however, prefer this policy option (more regulations and laws), when trying to reduce the shadow economy, mostly because it leads to an increase in power of the bureaucrats and to a higher rate of employment in the public sector. In this study the effect of government regulation on the development of the shadow economy will be investigated for developing, transition and highly developed countries.

\subsubsection{Public Sector Services}

An increase of the shadow economy can lead to reduced state revenues which in turn reduce the quality and quantity of publicly provided goods and services. Ultimately, this can lead to an increase in the tax rates for firms and individuals in the official sector, quite often combined with a deterioration in the quality of the public goods (such as the public infrastructure) and of the administration, with the consequence of even stronger incentives to participate in the shadow economy. Johnson, Kaufmann, and Zoido-Lobatón (1998a,b) present a simple model of this relationship. Their findings show that smaller shadow economies appear in countries with higher tax revenues, if achieved by lower tax rates, fewer 
laws and regulations and less bribery facing enterprises. Countries with a better rule of the law, which is financed by tax revenues, also have smaller shadow economies. Transition countries have higher levels of regulation leading to a significantly higher incidence of bribery, higher effective taxes on official activities and a large discretionary framework of regulations and consequently to a higher shadow economy. Their overall conclusion is that "wealthier countries of the OECD, as well as some in Eastern Europe find themselves in the 'good equilibrium' of relatively low tax and regulatory burden, sizeable revenue mobilization, good rule of law and corruption control, and [relatively] small unofficial economy. By contrast, a number of countries in Latin American and the Former Soviet Union exhibit characteristics consistent with a 'bad equilibrium': tax and regulatory discretion and burden on the firm is high, the rule of law is weak, and there is a high incidence of bribery and a relatively high share of activities in the unofficial economy." (Johnson, Kaufmann and ZoidoLobatón 1998a p. I). First results of corruption on the shadow economy and vice versa are reported in chapter 4 .

\subsubsection{Public Opinion about the Shadow Economy}

The perception of citizen/voters about the shadow economy and their (moral) reaction to this phenomenon is also an important factor, under which circumstances people decide to work in the shadow economy. There are a number of empirical studies, which investigate the tax moral of people and their attitudes against the shadow economy ${ }^{12}$. In this short section some results for Germany are shown which clearly demonstrate that people have no bad (moral) feeling when working in the shadow economy. In table 2.2 for the year 2003 it is investigated, whether people regularly work in the shadow economy or not. $25 \%$ of the German respondents say "yes", and $46 \%$ of the respondents regularly demand shadow economy activities. In table 2.3 some reasons are asked, why shadow economy activities are demanded. The most important result is, one saves money - or shadow economy activities are much cheaper than the official ones. The second most important reason is, that the tax and social security burden is too high ( $73 \%$ of the respondents) and reason number 3 is, that due to the much higher labour costs in the official economy, one would not demand this activities. Especially the third answer is interesting, because this result clearly demonstrates that only 23 $\%$ of the demanded shadow economy activities have substitutive character (i.e. they would demanded in the official economy if there would be no shadow economy) and only $9 \%$ of the

\footnotetext{
${ }^{12}$ Compare Halla and Schneider (2005), Torgler (2002), Torgler and Schneider (2005), Feld and Frey (2005), and Feld and Larsen (2005).
} 
respondents answer, they would do by themselves. From this survey result one can conclude that roughly $70 \%$ of these activities would not be taken place if there would be no shadow economy. In table 2.4 examples of some hourly wage rates of shadow economy activities in Germany are shown and what is here surprising, is the huge range of wage rates in the shadow economy, for example varying for an hours work of a painter between $€ 9$ an $€ 17$. Table 2.4 clearly demonstrates also the large difference (a multiplicative factor between 4 and 5) between the wage rates in the shadow economy and in the official one.

In table 2.5 important attitudes of the German population are shown, concentrating on the issue, what are "Kavaliersdelikte". These results convingly demonstrate over the years 1996 to 2003 that roughly two thirds of the German population treat shadow economy activities as a "Kavalierdelikt", where is "Stealing a newspaper from a box", only a third treats such a small theft as a "Kavaliersdelikt". In table 2.6 values statements of the German population with respect to the shadow economy are shown, again two thirds say that without shadow economy earnings one can not keep the achieved standard of living and only a third of the asked population means that shadow economy activities lead to great losses of tax revenues and social security payments to the state. What is most amazing in table 2.6 , are the attitudes of the German population with respect to punishment of shadow economy activities: only between $9 \%$ and $3 \%$ of the asked German population are convinced, that shadow economy workers should be reported to the authorities and prosecuted! A similar extreme low figure one gets, when asking if a shadow economy worker is detected, he should severely be punished. Only between $7 \%$ and $3 \%$ of the asked population say, "yes" this clearly shows that there is no bad (moral) feeling about working in the shadow economy among the German population. The results are quite similar for Austria.

Table 2.2: Work in the Shadow Economy - Survey Results for 2003

\begin{tabular}{|l|l|}
\hline $\begin{array}{l}\text { (1) Do you work regularly in the } \\
\text { shadow economy? (in order to earn } \\
\text { 300 Euro and more per month) }\end{array}$ & \\
\hline No & 72 \\
Yes & 25 \\
No answer & $(17 \%$ male) \\
\hline $\begin{array}{l}\text { (2) Do you demand regularly } \\
\text { shadow economy activities? }\end{array}$ & Values in percent \\
\hline $\begin{array}{l}\text { No } \\
\text { Yes }\end{array}$ & 54 \\
\hline Representative Questionnaire, Germany, May 2003, \\
\hline
\end{tabular}


Source: Schneider (2004)

Table 2.3: Reasons, for Shadow Economy Activities - Survey Results for Germany, May 2003

Reasons, why shadow economy activities are demanded

Values in percent

(1) One saves money - or they are much cheaper than in the official one

(2) The tax and social security burden is much too high $90 \%$

(3) Due to the high labour costs in the official economy one would not demand $73 \%$ these activities (extreme assumption no shadow economy: 23\% demand these activities in the official economy, 9\% make do-it-yourself)

(4) The firms offer them from themselves

(5) It's so easy to become quick and reliable persons

Representative questionnaire, Germany, May 2003, Source: Schneider(2004) 
Table 2.4: Hourly wage rates of shadow economy activities - Survey Results for Germany, 2004

\begin{tabular}{|c|c|c|c|}
\hline Activity/Type of Worker & Town/Area & $\begin{array}{c}\text { Wage rate in the } \\
\text { shadow economy (in } \\
€ \text { ) }\end{array}$ & $\begin{array}{c}\text { Wage rate in the } \\
\text { official economy (in } \\
€)\end{array}$ \\
\hline Painter & $\begin{array}{l}\text { Berlin } \\
\text { München } \\
\text { Rhein/Rhur }\end{array}$ & $\begin{array}{c}10-17 \\
9-15 \\
10-12\end{array}$ & 42 \\
\hline Mechanics & $\begin{array}{l}\text { Hamburg } \\
\text { Berlin } \\
\text { München }\end{array}$ & $\begin{array}{l}13-23 \\
15-19 \\
15-23\end{array}$ & 58 \\
\hline $\begin{array}{l}\text { Cost of a household } \\
\text { moving (distance } \\
300 \mathrm{~km})\end{array}$ & $\begin{array}{l}\text { Berlin } \\
\text { München } \\
\text { Rhein/Rhur }\end{array}$ & $\begin{array}{l}300-380 \\
400-450 \\
350-420\end{array}$ & 1.800 \\
\hline
\end{tabular}

Table 2.5: Values/Attitudes of the German population regarding shadow economy Question: What are „Kavaliersdelikte“ (neglegible delicts)?

\begin{tabular}{|l|c|c|c|c|c|}
\hline Statement & \multicolumn{5}{|c|}{ German Population (in \% Yes) } \\
\cline { 2 - 7 } & $\begin{array}{c}\text { May } \\
1996\end{array}$ & $\begin{array}{c}\text { May } \\
1998\end{array}$ & $\begin{array}{c}\text { May } \\
2001\end{array}$ & $\begin{array}{c}\text { Nov./Dec. } \\
2002\end{array}$ & $\begin{array}{c}\text { Nov./Dec. } \\
2003\end{array}$ \\
\hline $\begin{array}{l}\text { To demand activities in the } \\
\text { shadow economy }\end{array}$ & 55 & 64 & 60 & 68 & 67 \\
\hline To drive too quick with a car & 42 & 43 & 44 & 45 & 46 \\
\hline $\begin{array}{l}\text { To undertake oneself shadow } \\
\text { economy activities }\end{array}$ & 36 & 41 & 33 & 36 & 38 \\
\hline $\begin{array}{l}\text { Stealing a newspaper from a box } \\
\text { Not to send children to school }\end{array}$ & 28 & 29 & 31 & 30 & 28 \\
\hline $\begin{array}{l}\text { Not to be honest with the tax } \\
\text { declaration }\end{array}$ & 22 & 22 & 18 & - & 18 \\
\hline $\begin{array}{l}\text { Not to go to work (make „blue“ } \\
\text { on a Monday) }\end{array}$ & 18 & 17 & 16 & 13 & 12 \\
\hline To drive drunken & 9 & 4 & 7 & 3 & 4 \\
\hline Source: Schneider (2004) & & 24 & 18 & 18 \\
\hline
\end{tabular}


Table 2.6: Values/Attitudes of the German population regarding shadow economy Statements

\begin{tabular}{|l|l|l|l|l|c|}
\hline Statement & \multicolumn{3}{|c|}{ German Population (in \% Yes) } \\
\cline { 2 - 6 } & $\begin{array}{c}\text { May } \\
1996\end{array}$ & $\begin{array}{c}\text { May } \\
1998\end{array}$ & $\begin{array}{c}\text { May } \\
2001\end{array}$ & $\begin{array}{c}\text { Nov./Dec. } \\
2002\end{array}$ & $\begin{array}{c}\text { Nov./Dec. } \\
2003\end{array}$ \\
\hline $\begin{array}{l}\text { Without shadow economy earnings one cannot } \\
\text { keep up the standard of living }\end{array}$ & 62 & 69 & 69 & 70 & 71 \\
\hline $\begin{array}{l}\text { It's the state/government own fault that the } \\
\text { shadow economy is so popular and large, because } \\
\text { the tax and social security burden is too high }\end{array}$ & 63 & 67 & 57 & 66 & 67 \\
\hline $\begin{array}{l}\text { In the last 2-3 years I have demanded shadow } \\
\text { economy activities }\end{array}$ & 26 & 38 & 34 & 36 & 39 \\
\hline $\begin{array}{l}\text { Due to shadow economy activities the state } \\
\text { looses a great amount of tax revenues and social } \\
\text { security payments }\end{array}$ & 29 & 25 & 30 & 28 & 26 \\
\hline $\begin{array}{l}\text { In the neighbourhood one observes a lot of } \\
\text { shadow economy activities }\end{array}$ & - & - & 24 & 28 & 32 \\
\hline $\begin{array}{l}\text { I think, shadow economy workers should be } \\
\text { reported to the authorities and prosecuted }\end{array}$ & 9 & 4 & 6 & 3 & 3 \\
\hline $\begin{array}{l}\text { If a shadow economy worker is detected he } \\
\text { should be punished severely (high financial fines) }\end{array}$ & 7 & 4 & 5 & 7 & 3 \\
\hline \begin{tabular}{l} 
Source: Schneider (2004) \\
\hline
\end{tabular} & & & & \\
\hline
\end{tabular}

\subsubsection{Summary of the Main Causes of the Shadow Economy}

In table 2.7 an overview of a number of empirical studies is given which summarizes the empirical results of the various factors influencing the shadow economy. In table 2.7 we have to two columns, showing the various factors influencing the shadow economy with and without the independent variable, "tax moral". This table clearly demonstrates that the increase of the tax and social security contribution burdens is by far most important single influence of the increase of the shadow economy. This factor does "explain" between 35 $38 \%$ or $45-52 \%$ of the variance of the shadow economy with and without including the variable "tax moral", then follows the variable tax moral which "explains" between $22-25 \%$ 
of the variance of the shadow economy ${ }^{13}$ and finally follows a third factor, "intensity of state regulation "(mostly for the labour market). In general table 2.7 shows, that the independent variables tax and social security burden followed by variables tax moral and by intensity of state regulations are the three major driving forces of the shadow economy.

Table 2.7: Main Causes of the Increase of the Shadow Economy

Factors Influencing the Shadow Economy

\begin{tabular}{|l|l|l|}
\hline The most important driving forces are: & \multicolumn{2}{|l|}{ Influence on the shadow economy (in\%) 1) } \\
\hline $\begin{array}{l}\text { (1) Increase of the Tax and Social Security } \\
\text { Contribution Burdens }\end{array}$ & $35-38 \%$ & $45-52 \%$ \\
\hline (2) Intensity of State Regulations & $8-10 \%$ & $10-15 \%$ \\
\hline (3) Social Transfers & $5-7 \%$ & $5-8 \%$ \\
\hline (4) Specific Labor Market Regulations & $5-7 \%$ & $5-8 \%$ \\
\hline (5) Public Sector Services & $5-7 \%$ & $5-8 \%$ \\
\hline (6) Tax Morale 2) & $22-25 \%$ & - \\
\hline Overall influence & $76-94 \%$ & $70-90 \%$ \\
\hline
\end{tabular}

1) Average values of empirical results of 28 studies.

2) Average values of „only“ 15 studies

Source: Schneider (2004)

\section{The Size of the Shadow Economies for 145 Countries}

\subsection{Econometric Results}

In tables 3.1 to 3.3 the econometric estimations using the DYMIMIC approach (latent estimation approach) are presented for the 96 developing countries, the 28 (25) transition and 3 communist countries and the 21 industrialized (highly developed) OECD-countries. ${ }^{14)}$ This grouping was necessary because the available data situation is different for these countries. For the 96 developing countries and the 28 transition and communist countries the estimation

\footnotetext{
13 The innocence of this variable with respect to theory and empirical importance is also shown in Feld and Frey (2002, 2002a and 2005), Frey (1997), and Torgler and Schneider (2005)

14) The classification which country is a developing country follows the one done by the World Bank (2002) using a benchmark a per capita income of 9,265 USD or less. The others with a higher income are either transition or industrialized countries (here 21 OECD countries). The grouping of the transition countries is done following the grouping in of the OECD country studies (Paris, various years).
} 
was done for three different points of time 1999/2000, 2001/02 and 2002/03 and for the 21 OECD countries I have six data points of time 1990/91, 1994/95, 1997/98, 1999/2000, 2001/02 and 2002/03. For the developing and transition countries I use as cause variables the following ones: share of direct and indirect taxation (in \% of GDP) as the two tax burden variables; burden of state regulation (Index of regulation, Heritage Foundation, 2005), unemployment quota and GDP per capita as two cause variables for the status of the "official" economy. As indicator variables I use the employment quota (in \% of the population between 18 and 64), annual rate of GDP, and annual rate of local currency per capita. ${ }^{15)}$ For the OECD countries I use as additional cause variables the burden of social security payments, the tax morale, quality of state institutions and an index of the regulation of the labor market.

The estimation results for the 96 developing countries in Middle and South America, Africa, Asia and South West Pacific Islands are shown in table 3.1. All estimated coefficients of the independent cause variables are statistically significant and have the theoretically expected signs. If one first considers the two tax burden variables one realizes, that the share of direct taxation is just statistically significant (90\% confidence level) and the size of the estimated coefficient has half the size of the value of the share of indirect taxation and custom duties which is highly statistically significant and the estimated coefficient has a much larger size. One can interpret this result, that direct taxation is a less important for the development of the shadow economy in developing countries, compared to indirect taxation and custom duties. If one turns to the burden of state regulation, the Heritage Foundation index, this variable is highly statistically significant, like the two variables, measuring the official economy, unemployment quota and GDP per capita. As a single independent variable, the burden of state regulation, has the quantitative largest impact on the size of the shadow economy, showing that state regulation is the most important factor for the size of the shadow economy in developing countries. But also the official labor market is quite important, the unemployment quota has the second largest estimated coefficient and influence on the shadow economy in the 96 developing countries in Middle and South America, Africa, Asia and South West Pacific Islands. If we turn to the indicator variables, we see, that the employment quota as well as the change of local currency per capita have the expected negative and positive influence and are highly statistically significant. ${ }^{16)}$

\footnotetext{
${ }^{15)}$ Here I have the problem, that in some developing and transition countries the US-\$ (or Euro) is also a widely used currency, which is not considered here, because I got no reliable figures of the amount of US-\$ (Euro) in these developing and transition countries.

16) The estimation results are in general robust, if other indicator variables are used as residuum; e.g. if the variable currency per capita is used as residuum the share of direct taxation becomes insignificant as well as the variable GPD per capita.
} 
In table 3.2 the estimation results are presented for the 25 transition countries in Central and East Europe and of former Soviet Union Countries and 3 communist countries ${ }^{17}$. Again all estimated coefficients of the cause variables are statistically significant and similar as in the case of the developing countries the two tax burden variables have together the quantitative largest impact on the size of the shadow economy. Opposite to the results of the 96 developing countries, the cause variable, "share of direct taxation" (including social security payments) has a highly statistically significant influence with the expected positive sign on the shadow economy. Also the independent variable "share of indirect taxation" has a highly statistically significant influence, but the estimated coefficient is somewhat smaller then compared to the one the share of direct taxation (including social security payments). The variable, "unemployment quota" has also the expected positive influence and is highly statistically significant and has the second largest estimated coefficient. The indicator variables, "employment quota", and, "the annual rate of currency per capita" have the theoretically expected signs and are statistically highly significant.

Finally, in table 3.3 the results for 21 highly developed OECD countries are shown. For these countries the availability of data is somewhat better: Not only have I more data points over time but also I have three additional cause variables, tax morale (an index), quality of state institutions and now, as separate variable, the burden of social security payments (in \% of GDP). The additional indicator variable is the average working time (per week). ${ }^{18)}$ The estimated coefficients of all eight cause variables are statistically significant and have the theoretically expected signs. The tax and social security burden variables are quantitatively the most important ones followed by the tax moral variable which has the single biggest influence; hence the tax payers attitude against the state institutions/government is quite important to determine whether one is engaged in shadow economy activities or not. Also the development of the official economy measured in unemployment and GDP per capita has a quantitative important influence on the shadow economy. Turning to the four indicator variables they all have a statistically significant influence and the estimated coefficients have the theoretically expected signs. The quantitatively most important independent variables are the employment quota and change of currency per capita. ${ }^{19)}$

\footnotetext{
${ }^{17}$ How useful it is to conclude the three communist countries in this estimation, is an open and debatable question, as these countries have only a somewhat limited market system. Hence they may not fit in this sample, which may be a point of criticism.

18) Using this indicator variable one has the problem that, of course, this variable is influenced by state regulation, so that this variable is not really exogenous; hence the estimation may be biased.

${ }^{19)}$ The variable currency per capita or annual change of currency per capita is heavily influenced by banking 
Summarizing, the econometric results demonstrate that for all three groups of countries the theoretical considerations about the causes of the shadow economy in section 2 can be confirmed: The direct tax (and social security) payment and indirect tax burden variables are the driving forces of the growth of the shadow economy for all three types of countries (developing, transition and highly developed OECD countries), followed by the measure of state regulation and as measures of the official economy the unemployment quota and GDP per capita. In the developing country the largest influence has the burden of state regulation, followed by the unemployment quota and the share of indirect taxation. In the transition countries direct taxation (including social security payments) has the largest influence, followed by the unemployment quota and share of indirect taxation. In the highly developed OECD countries, the social security contributions and share of direct taxation has the biggest influence, followed by the tax morale and quality of state institutions. From these results we see that there are some differences, which influence the shadow economy according to these three different country groups. ${ }^{20)}$

innovations; hence this variable is pretty unstable in the estimations with respect to the length of the estimation period. Similar problems are already mentioned by Giles (1999a) and Giles and Tedds (2002).

${ }^{20)}$ Due to space considerations it is not possible to make here an extensive discussion why we observe these differences. The author currently is doing an extensive research on these differences which will come out in a discussion paper this fall. 


\section{Table 3.1: DYMIMIC Estimations of the size of the shadow economy of 96 developing countries in Middle and South America, Africa, Asia and South West Pacific Islands over 1999/00, 2001/02 and 2002/03}

\begin{tabular}{|c|c|}
\hline Cause Variables & Estimated Coefficients \\
\hline $\begin{array}{l}\text { Share of direct taxation } \\
\text { (in \% of GDP) }\end{array}$ & $\begin{array}{c}\lambda 1=0.16^{(*)} \\
(1.77)\end{array}$ \\
\hline $\begin{array}{l}\text { Share of indirect taxation } \\
\text { and custom duties (in \% of GDP) }\end{array}$ & $\begin{array}{c}\lambda 2=0.256^{* *} \\
(3.34)\end{array}$ \\
\hline $\begin{array}{l}\text { Burden of state regulation (Index, Heritage } \\
\text { Found., score } 1 \text { most economic freedom, } 5 \\
\text { least economic freedom) }\end{array}$ & $\begin{array}{c}\lambda 3=0.309^{* *} \\
(2.84)\end{array}$ \\
\hline Unemployment quota $(\%)$ & $\begin{array}{c}\lambda 4=0.296^{* *} \\
(3.96)\end{array}$ \\
\hline GDP per capita (in US-\$) & $\begin{array}{l}\lambda 5=-0.151^{*} \\
\quad(-2.56)\end{array}$ \\
\hline Lagged endogenous variable & $\begin{array}{c}\lambda 6=0.341^{(*)} \\
(1.76)\end{array}$ \\
\hline \multicolumn{2}{|l|}{ Indicator Variables } \\
\hline $\begin{array}{l}\text { Employment quota } \\
\text { (in \% of population 18-64) }\end{array}$ & $\begin{array}{c}\lambda 7=-0.651 * * \\
\quad(-3.45)\end{array}$ \\
\hline Annual rate of GDP & $\lambda 8=-1($ Residuum $)$ \\
\hline $\begin{array}{l}\text { Change of local currency } \\
\text { per capita }\end{array}$ & $\begin{array}{c}\lambda 9=0.412^{* *} \\
(4.99)\end{array}$ \\
\hline Test-statistics & $\begin{array}{c}\mathrm{RMSE}^{1)}=0.0004^{(*)}(\mathrm{p} \text {-value }=0.952) \\
\text { Chi-square }^{2)}=7.53(\mathrm{p} \text {-value }=0.904) \\
\mathrm{TMNCV}^{3)}=0.042 \\
\mathrm{AGFI}^{4)}=0.774 \\
\mathrm{~N}=288 \\
\text { D.F. }^{5)}=34\end{array}$ \\
\hline \multicolumn{2}{|c|}{$\begin{array}{l}\text { Notes: } \\
\text { t-statistics are given in parentheses }(*) ; * ; * \text { means the t-statistics is statistically significant at the } \\
90 \%, 95 \% \text {, or } 99 \% \text { confidence level. } \\
\text { 1) Steigers Root Mean Square Error of Approximation (RMSEA) for test of close fit; RMSEA }<0.05 \text {; } \\
\text { the RMSEA-value varies between } 0.0 \text { and } 1.0 \text {. } \\
\text { 2) If the structural equation model is asymptotically correct, then the matrix } \mathrm{S} \text { (sample covariance } \\
\text { matrix) will be equal to } \Sigma(\theta) \text { (model implied covariance matrix). This test has a statistical validity } \\
\text { with a large sample }(\mathrm{N} \geq 100 \text { ) and multinomial distributions; both is given for a all three equations } \\
\text { in tables } 3.1-3.3 \text { using a test of multi normal distributions. } \\
\text { 3) Test of Multivariate Normality for Continuous Variables (TMNCV); p-values of skewness and } \\
\text { kurtosis. } \\
\text { 4) Test of Adjusted Goodness of Fit Index (AGFI), varying between } 0 \text { and } 1 ; 1=\text { perfect fit. } \\
\text { 5) The degrees of freedom are determined by } 0.5(p+q)(p+q+1)-t \text {; with } p=\text { number of } \\
\text { indicators; } q=\text { number of causes; } t=\text { the number for free parameters. }\end{array}$} \\
\hline
\end{tabular}




\section{Table 3.2: DYMIMIC Estimation of the Shadow Economy of 25 Central and East European and Former Soviet Union Countries and 3 Communist Countries, Years 1999/00, 2001/02 and 2002/03}

\section{Cause Variables}

Share of direct taxation

+ share of social security payments (in $\%$ of GDP)

Share of indirect taxation

+ custom duties (in \% of GDP)

Burden of state regulation (Index, Heritage

Found., score 1 most economic freedom, 5

least economic freedom)

Unemployment quota (\%)

\section{Estimated Coefficients}

$\lambda 1=0.461^{* *}$

(3.71)

$\lambda 2=0.361^{* *}$

(3.31)

$\lambda 3=0.192 *$

(2.48)

$\lambda 4=0.391^{* *}$

(3.91)

GDP per capita (in US-\$)

Lagged endogenous variable

Indicator Variables

Employment quota

(as \% of population 18-64)

Annual rate of GDP

$\lambda 8=-1.00$ (Residuum)

Change of local currency

per capita

Test-statistics $\lambda 5=-0.221^{* *}$

$(-3.77)$

$\lambda 6=0.284^{*}$

(2.06)

$$
\lambda 9=0.432 * *
$$

(3.88)

$\operatorname{RMSE}^{1)}=0.0003^{(*)}(\mathrm{p}$-value $=0.914)$

Chi-square $^{2)}=403.41(\mathrm{p}$-value $=0.762)$

$$
\begin{gathered}
\mathrm{TMCV}^{3)}=0.091 \\
\mathrm{AGFI}^{4)}=0.661 \\
\mathrm{~N}=84 \\
\text { D.F. }^{5)}=33
\end{gathered}
$$

\section{Notes:}

t-statistics are given in parentheses $(*) ; * ; *$ means the t-statistics is statistically significant at the $90 \%, 95 \%$, or $99 \%$ confidence level.

1) Steigers Root Mean Square Error of Approximation (RMSEA) for test of close fit; RMSEA < 0.05 ; the RMSEA-value varies between 0.0 and 1.0.

2) If the structural equation model is asymptotically correct, then the matrix $\mathrm{S}$ (sample covariance matrix) will be equal to $\Sigma(\theta)$ (model implied covariance matrix). This test has a statistical validity with a large sample $(\mathrm{N} \geq 100)$ and multinomial distributions; both is given for a all three equations in tables 3.1.1-3.1.3 using a test of multi normal distributions.

3) Test of Multivariate Normality for Continuous Variables (TMNCV); p-values of skewness and kurtosis.

4) Test of Adjusted Goodness of Fit Index (AGFI), varying between 0 and 1; $1=$ perfect fit.

5) The degrees of freedom are determined by $0.5(\mathrm{p}+\mathrm{q})(\mathrm{p}+\mathrm{q}+1)-\mathrm{t}$; with $\mathrm{p}=$ number of indicators; $\mathrm{q}=$ number of causes; $\mathrm{t}=$ the number for free parameters. 


\section{Table 3.3: DYMIMIC Estimation of the Shadow Economy of 21 highly developed OECD Countries, years 1990/91, 1994/95, 1997/98, 1999/2000, 2001/02 and 2002/03}

\section{Cause Variables}

Share of direct taxation

(in $\%$ of GDP)

Share of indirect taxation

(in $\%$ of GDP)

Share of social security contribution (in $\%$ of GDP)

Burden of state regulation (index of labour market regulation, Heritage Found., score 1 least reg., score 5 most reg.)

Quality of state institutions (rule of law, World Bank, score -3 worst and +3 best case)

Tax morale (WUS and EUS, Index, Scale tax cheating always justified $=1$, never justified $=10)$

Unemployment quota (\%)

GDP per capita (in US-\$)

Lagged endogenous variable

Indicator Variables

Employment quota

(in \% of population 18-64)

Average working time (per week)

Annual rate of GDP (adjusted for the mean of all 22 OECD countries)

Change of local currency per capita

\begin{tabular}{|l|c|}
\hline Test-statistics & RMSE $^{1)}=0.0002 *(\mathrm{p}$-value $=0.981)$ \\
& Chi-square $^{2)}=6.54(\mathrm{p}$-value $=0.921)$ \\
& $\mathrm{TMCV}^{3)}=0.038$ \\
& $\mathrm{AGFI}^{4)}=0.814$ \\
$\mathrm{~N}=126$ \\
D.F. ${ }^{5}=61$
\end{tabular}

\section{Estimated Coefficients}

$\lambda 1=0.410^{*}$

(3.41)

$\lambda 2=0.213(*)$

$\lambda 3=0.523 * *$

(4.59)

$\lambda 4=0.203(*)$

(1.84)

$\lambda 5=-0.346^{* *}$

$(-2.76)$

$\lambda 6=-0.614^{* *}$

$(-4.06)$

$\lambda 7=0.399 * *$

(3.41)

$\lambda 8=-0.134 * *$

$(-3.64)$

$\lambda 9=-0.174^{(*)}$

$(-1.78)$

Estimated Coefficients

$\lambda 10=-0.713 * *$

$(-3.49)$

$\lambda 11=-1.00$ (Residuum)

$\lambda 12=-0.345^{* *}$

$(-3.513)$

$\lambda 13=0.384^{* *}$

(4.71) 
$90 \%, 95 \%$, or $99 \%$ confidence level.

1) Steigers Root Mean Square Error of Approximation (RMSEA) for test of close fit; RMSEA < 0.05; the RMSEA-value varies between 0.0 and 1.0.

2) If the structural equation model is asymptotically correct, then the matrix $\mathrm{S}$ (sample covariance matrix) will be equal to $\Sigma(\theta)$ (model implied covariance matrix). This test has a statistical validity with a large sample $(\mathrm{N} \geq 100)$ and multinomial distributions; both is given for a all three equations in tables 3.1.1-3.1.3 using a test of multi normal distributions.

3) Test of Multivariate Normality for Continuous Variables (TMNCV); p-values of skewness and kurtosis.

4) Test of Adjusted Goodness of Fit Index (AGFI), varying between 0 and 1; $1=$ perfect fit.

5) The degrees of freedom are determined by $0.5(p+q)(p+q+1)-t$; with $p=$ number of indicators; $q=$ number of causes; $t=$ the number for free parameters.

In order to calculate the size and development of the shadow economies of 145 countries, I have to overcome the disadvantage of the DYMIMIC approach, which is; that one gets only relative estimated sizes of the shadow economy and one has to use another approach to get absolute figures. In order to calculate absolute figures of the size of the shadow economies from these DYMIMIC estimation results I use the already available estimations from the currency demand approach for Australia, Austria, Germany, Hungary, Italy, India, Peru, Russia and the United States (from studies of Chatterjee, Chaudhury and Schneider (2006), Del'Anno and Schneider (2004), Bajada and Schneider (2003, 2005), Alexeev and Pyle (2003), Schneider and Enste (2002) and Lacko (2000)). As I have values of the shadow economy (in \% of GDP) for various years for the above mentioned countries, I can use a benchmark procedure with the help of the currency demand estimation with figures to transform the index of the shadow economy from the DYMIMIC estimations into cardinal values. $^{21)}$

\subsection{The Size of the Shadow Economies for 145 Countries for 1999/2000, 2001/2002 and 2002/2003}

When showing the size of the shadow economies over the three periods of time $(1999 / 2000$, 2001/2002 and 2002/2003) for the 145 countries which are quite different in location and developing stage, one should be aware that such country comparison give only a rough picture of the ranking of the size of the shadow economy over the countries and over time, because the DYMIMIC and the currency demand methods have shortcomings which are discussed in

\footnotetext{
${ }^{21)}$ This procedure is described in great detail in the paper Del'Anno and Schneider (2005).
} 
appendix (chapter 5) ${ }^{22)}$. Due to these shortcomings a detailed discussion of the (relative) ranking of the size of the shadow economies is not done.

\subsubsection{Developing Countries ${ }^{23}$}

The results of the shadow economies for developing countries are divided by continent into Africa, Asia, and Central and South America, and are shown in Tables 3.2.1-3.2.3. The results for thirty-seven African countries are shown in Table 3.2.1. If we first consider the development of the shadow economies in these thirty-seven African countries from 19992000, we realize that shadow economy in these African nations has increased. On average, the size of these thirty-seven African shadow economies was $41.3 \%$ of official GDP in $1999 / 2000$, and increased to $43.2 \%$ in $2002 / 2003$. This is an average increase of 0.9 percentage points over four years. Turning to the latest results for 2002/2003, Zimbabwe, Tanzania, and Nigeria (with 63.2, 60.2 and 59.4\% respectively) have by far the largest shadow economies, and the country in the median position is Mozambique with $42.4 \%$. South Africa has the lowest shadow economy, with $29.5 \%$, followed by Lesotho with $33.3 \%$, and Namibia with $33.4 \%$.

The large shadow economy in Africa (and in other developing countries) is only to some extend an issue of tax burdens than the simple fact that the limited local economy means that citizens are often unable to earn a living wage in a legitimate manner. Working in the shadow economy is often the only way of achieving a minimal standard of living.

Table 3.2.1: The Size of the Shadow Economy in Thirty-Seven African Countries

\begin{tabular}{|l|l|l|l|l|}
\hline \multirow{2}{*}{ No. } & Country & \multicolumn{3}{|c|}{$\begin{array}{l}\text { Shadow Economy (in \% of off. GDP) using } \\
\text { the DYMIMIC and Currency Demand Method }\end{array}$} \\
\cline { 3 - 5 } & Algeria & $\mathbf{1 9 9 9 / 0 0}$ & $\mathbf{2 0 0 1 / 0 2}$ & $\mathbf{2 0 0 2 / 0 3}$ \\
\hline $\mathbf{2}$ & Angola & 34,1 & 35,0 & 35,6 \\
3 & Benin & 43,2 & 44,1 & 45,2 \\
4 & Botswana & 47,3 & 48,2 & 49,1 \\
5 & Burkina Faso & 33,4 & 33,9 & 34,6 \\
6 & Burundi & 41,4 & 42,6 & 43,3 \\
\end{tabular}

\footnotetext{
${ }^{22)}$ See also Thomas (1992, 1999), Tanzi (1999), Pedersen (2003) and Ahumada, Alveredo, Cavanese A and P. Cavanese (2004), Janisch and Brümmerhoff (2005), Schneider (2005) and Breusch (2005a, 2005b).

${ }^{23}$ For an extensive and excellent literature survey of the research about the shadow economy in developing countries see Gerxhani (2003),who stresses thorough out her paper that the destination between developed and developing countries with respect to the shadow economy is of great importance. Due to space reasons this point is not further elaborated here also the former results and literature are not discussed here. Compare Schneider and Enste (2000)
} 


\begin{tabular}{|c|c|c|c|c|}
\hline 7 & Cameroon & 32,8 & 33,7 & 34,9 \\
\hline 8 & Central African Republic & 44,3 & 45,4 & 46,1 \\
\hline 9 & Chad & 46,2 & 47,1 & 48,0 \\
\hline 10 & Congo, Dem. Rep. & 48,0 & 48,8 & 49,7 \\
\hline 11 & Congo, Rep. & 48,2 & 49,1 & 50,1 \\
\hline 12 & Cote d'Ivoire & 43,2 & 44,3 & 45,2 \\
\hline \multirow[t]{2}{*}{13} & Egypt, Arab Rep. & 35,1 & 36,0 & 36,9 \\
\hline & & \multicolumn{3}{|c|}{$\begin{array}{l}\text { Shadow Economy (in \% of off. GDP) using } \\
\text { the DYMIMIC and Currency Demand Method }\end{array}$} \\
\hline No. & Country & 1999/00 & 2001/02 & $2002 / 03$ \\
\hline 14 & Ethiopia & 40,3 & 41,4 & 42,1 \\
\hline 15 & Ghana & 41,9 & 42,7 & 43,6 \\
\hline 16 & Guinea & 39,6 & 40,8 & 41,3 \\
\hline 17 & Kenya & 34,3 & 35,1 & 36,0 \\
\hline 18 & Lesotho & 31,3 & 32,4 & 33,3 \\
\hline 19 & Madagascar & 39,6 & 40,4 & 41,6 \\
\hline 20 & Malawi & 40,3 & 41,2 & 42,1 \\
\hline 21 & Mali & 42,3 & 43,9 & 44,7 \\
\hline 22 & Mauritania & 36,1 & 37,2 & 38,0 \\
\hline 23 & Morocco & 36,4 & 37,1 & 37,9 \\
\hline 24 & Mozambique & 40,3 & 41,3 & 42,4 \\
\hline 25 & Namibia & 31,4 & 32,6 & 33,4 \\
\hline 26 & Niger & 41,9 & 42,6 & 43,8 \\
\hline 27 & Nigeria & 57,9 & 58,6 & 59,4 \\
\hline 28 & Rwanda & 40,3 & 41,4 & 42,2 \\
\hline 29 & Senegal & 45,1 & 46,8 & 47,5 \\
\hline 30 & Sierra Leone & 41,7 & 42,8 & 43,9 \\
\hline 31 & South Africa & 28,4 & 29,1 & 29,5 \\
\hline 32 & Tanzania & 58,3 & 59,4 & 60,2 \\
\hline 33 & Togo & 35,1 & 39,2 & 40,4 \\
\hline 34 & Tunisia & 38,4 & 39,1 & 39,9 \\
\hline 35 & Uganda & 43,1 & 44,6 & 45,4 \\
\hline 36 & Zambia & 48,9 & 49,7 & 50,8 \\
\hline 37 & Zimbabwe & 59,4 & 61,0 & 63,2 \\
\hline \multicolumn{2}{|c|}{ Unweighted Average } & 41,3 & 42,3 & 43,2 \\
\hline
\end{tabular}

In Table 3.2.2, the results for twenty-eight Asian countries are shown; it is somewhat difficult to treat all Asian countries equally because some, such as Israel, Singapore, and Hong Kong, are highly developed, while others such as Thailand and Nepal, are still developing. The average shadow economy in the region increased from $28.9 \%$ in $1999 / 2000$, to $30.8 \%$ of official GDP in $2002 / 2003$, which is an increase of 1.9 percentage points over four years. Looking at individual countries ${ }^{24)}$ for the year 2002/2003, with 54.1\% Thailand has by far the largest shadow economy, followed by Cambodia with $52.4 \%$, and Sri Lanka with $47.2 \%$ of official GDP. The median country is the Republic of Korean with $28.2 \%$ of official GDP, surrounded by Yemen with $29.1 \%$ and United Arab Emirates with 27.8\%. Singapore, Hong Kong, and Saudi Arabia have the lowest shadow economies with $13.7 \%, 17.2 \%$, and $19.7 \%$ of official GDP, respectively.

${ }^{24)}$ The case of India has been extensively investigated by Chatterjee, Chaudhury and Schneider (2006). 
It is clear that the average size of the Asian shadow economies is considerably smaller than the shadow economies of African and Latin American states-this is partly due to the fact that there are a greater number of developed countries, which have smaller shadow economies located in Asia. It should be noted, however, that average increase of the shadow economies in the region is slightly more rapid than in Africa. This is not surprising given that size of the average African shadow economy is already more then eleven percentage points higher than its Asian counterpart. There is simply more room for growth in Asia.

Table 3.2.2: The Size of the Shadow Economy in Twenty-Eight Asian Countries

\begin{tabular}{|l|l|l|l|l|}
\hline \multirow{2}{*}{ No. } & \multicolumn{3}{|l|}{ Shadow Economy (in \% of off. GDP) using the } \\
DYMIMIC and Currency Demand Method
\end{tabular}

In Table 3.2.3, the sizes of shadow for twenty-one Central and South American countries are shown. Averaging the figures in all twenty-one Central and South American countries, the shadow economy increased from $41.1 \%$ in the year $1999 / 2000$ to $43.4 \%$ of official GDP in 2002/2003; an increase of 2.3 percentage points over these four years. If I now turn to the size of the shadow economy for single countries for 2002/2003, Bolivia has the largest shadow economy with $68.3 \%$, followed by Panama 
with $65.3 \%$. and Peru with $60.9 \%$ of official GDP. The median country is Brazil with $42.3 \%$ and at the lower end are Chile with 20.9\%, Costa Rica with 27.8\%, and Argentina with $28.9 \%$ of official GDP.

The sizes of the shadow economies of African and Central and South American countries are generally similar. This is partly due to the factors mentioned earlier; for the majority of citizens in many of these countries, the only way to ensure a decent standard of living is to turn to the black market. As income inequality is much more pronounced in most Central and South American countries, compared to Africa, the rate of increase of in shadow economy activity in Central and South America is higher.

Table 3.2.3: The Size of the Shadow Economy in Twenty-One Central and South American Countries

\begin{tabular}{|c|c|c|c|c|}
\hline \multirow[b]{2}{*}{ No. } & \multirow[b]{2}{*}{ Country } & \multicolumn{3}{|c|}{$\begin{array}{l}\text { Shadow Economy (in \% of off. GDP) using the } \\
\text { DYMIMIC and Currency Demand Method }\end{array}$} \\
\hline & & $1999 / 00$ & $2001 / 02$ & $2002 / 03$ \\
\hline 1 & Argentina & 25,4 & 27,1 & 28,9 \\
\hline 2 & Bolivia & 67,1 & 68,1 & 68,3 \\
\hline 3 & Brazil & 39,8 & 40,9 & 42,3 \\
\hline 4 & Chile & 19,8 & 20,3 & 20,9 \\
\hline 5 & Colombia & 39,1 & 41,3 & 43,4 \\
\hline 6 & Costa Rica & 26,2 & 27,0 & 27,8 \\
\hline 7 & Dominican Republic & 32,1 & 33,4 & 34,1 \\
\hline 8 & Ecuador & 34,4 & 35,1 & 36,7 \\
\hline 9 & El Salvador & 46,3 & 47,1 & 48,3 \\
\hline 10 & Guatemala & 51,5 & 51,9 & 52,4 \\
\hline 11 & Haiti & 55,4 & 57,1 & 58,6 \\
\hline 12 & Honduras & 49,6 & 50,8 & 51,6 \\
\hline 13 & Jamaica & 36,4 & 37,8 & 38,9 \\
\hline 14 & Mexico & 30,1 & 31,8 & 33,2 \\
\hline 15 & Nicaragua & 45,2 & 46,9 & 48,2 \\
\hline 16 & Panama & 64,1 & 65,1 & 65,3 \\
\hline 17 & Paraguay & 27,4 & 29,2 & 31,4 \\
\hline 18 & Peru & 59,9 & 60,3 & 60,9 \\
\hline 19 & Puerto Rico & 28,4 & 29,4 & 30,7 \\
\hline 20 & Uruguay & 51,1 & 51,4 & 51,9 \\
\hline 21 & Venezuela, RB & 33,6 & 35,1 & 36,7 \\
\hline \multicolumn{2}{|c|}{ Unweighted Average } & 41,1 & 42,2 & 43,4 \\
\hline
\end{tabular}

\subsubsection{Transition Countries}

The measurement of the size and development of the shadow economy in the transition countries has been undertaken since the late 80s starting with the work of Kaufmann and Kaliberda (1996), Johnson et.al. (1997) and Lacko (2000). They all are using the physical input (electricity) method (see Appendix 7.1.2.5) and come up with quite large figures. In the work of Alexeev and Pyle (2003) and Belev (2003) the above mentioned studies are critically evaluated arguing that the 
estimated sizes of the unofficial economies are to a large content a historical phenomenon and partly determined by institutional factors.

In table 3.2.4 the size and development of the shadow economy of 25 East and Central European and Former Soviet Union countries are presented. Turning again first to the development of the size of the shadow economy over time, the average size of the shadow economy of these 25 East and Central European countries was 38.1\% of official GDP in 1999/2000 and increased to 40.1\% in 2002/2003 which is an increase of 2 percentage points over these four years. The highest shadow economies have Georgia, Azerbaijan and the Ukraine with $68.0 \%, 61.3 \%$ and $54.7 \%$. The median country is Bulgaria, surrounded by Serbia and Montenegro of 39.1\% and Romania of $37.4 \%$. At the lower end are the Czech Republic with 20.1\%, the Slovak Republic with $20.2 \%$ and Hungary with $26.2 \%$ of official GDP.

Table 3.2.4: The Size of the Shadow Economy in 25 East and Central European and Former Soviet Union Countries

\begin{tabular}{|c|c|c|c|c|}
\hline \multirow[b]{2}{*}{ No. } & \multirow[b]{2}{*}{ Country } & \multicolumn{3}{|c|}{$\begin{array}{l}\text { Shadow Economy (in \% of off. GDP) using the } \\
\text { DYMIMIC and Currency Demand Method }\end{array}$} \\
\hline & & $1999 / 00$ & $2001 / 02$ & $2002 / 03$ \\
\hline 1 & Albania & 33,4 & 34,6 & 35,3 \\
\hline 2 & Armenia & 46,3 & 47,8 & 49,1 \\
\hline 3 & Azerbaijan & 60,6 & 61,1 & 61,3 \\
\hline 4 & Belarus & 48,1 & 49,3 & 50,4 \\
\hline 5 & Bosnia and Herzegovina & 34,1 & 35,4 & 36,7 \\
\hline 6 & Bulgaria & 36,9 & 37,1 & 38,3 \\
\hline 7 & Croatia & 33,4 & 34,2 & 35,4 \\
\hline 8 & Czech Republic & 19,1 & 19,6 & 20,1 \\
\hline 9 & Estonia & 38,4 & 39,2 & 40,1 \\
\hline 10 & Georgia & 67,3 & 67,6 & 68,0 \\
\hline 11 & Hungary & 25,1 & 25,7 & 26,2 \\
\hline 12 & Kazakhstan & 43,2 & 44,1 & 45,2 \\
\hline 13 & Kyrgyz Republic & 39,8 & 40,3 & 41,2 \\
\hline 14 & Latvia & 39,9 & 40,7 & 41,3 \\
\hline 15 & Lithuania & 30,3 & 31,4 & 32,6 \\
\hline 16 & Macedonia, FYR & 34,1 & 35,1 & 36,3 \\
\hline 17 & Moldova & 45,1 & 47,3 & 49,4 \\
\hline 18 & Poland & 27,6 & 28,2 & 28,9 \\
\hline 19 & Romania & 34,4 & 36,1 & 37,4 \\
\hline 20 & Russian Federation & 46,1 & 47,5 & 48,7 \\
\hline 21 & Serbia and Montenegro & 36,4 & 37,3 & 39,1 \\
\hline 22 & Slovak Republic & 18,9 & 19,3 & 20,2 \\
\hline 23 & Slovenia & 27,1 & 28,3 & 29,4 \\
\hline 24 & Ukraine & 52,2 & 53,6 & 54,7 \\
\hline 25 & Uzbekistan & 34,1 & 35,7 & 37,2 \\
\hline \multicolumn{2}{|c|}{ Unweighted Average } & 38,1 & 39,1 & 40,1 \\
\hline
\end{tabular}




\subsubsection{Highly developed OECD-Countries}

The size and development of 21 highly developed OECD countries is shown in table 3.2.5.

Table 3.2.5: The Size of the Shadow Economy in 21 OECD Countries

\begin{tabular}{|c|c|c|c|c|}
\hline & \multirow[b]{2}{*}{ Country } & \multicolumn{3}{|c|}{$\begin{array}{l}\text { Shadow Economy (in \% of off. GDP) using the DYMIMIC } \\
\text { and Currency Demand Method }\end{array}$} \\
\hline & & $1999 / 00$ & $2001 / 02$ & $2002 / 03$ \\
\hline 1 & Australia & 14,3 & 14,1 & 13,5 \\
\hline 2 & Austria & 9,8 & 10,6 & 10,9 \\
\hline 3 & Belgium & 22,2 & 22,0 & 21,0 \\
\hline 4 & Canada & 16,0 & 15,8 & 15,2 \\
\hline 5 & Denmark & 18,0 & 17,9 & 17,3 \\
\hline 6 & Finland & 18,1 & 18,0 & 17,4 \\
\hline 7 & France & 15,2 & 15,0 & 14,5 \\
\hline 8 & Germany & 16,0 & 16,3 & 16,8 \\
\hline 9 & Greece & 28,7 & 28,5 & 28,2 \\
\hline 10 & Ireland & 15,9 & 15,7 & 15,3 \\
\hline 11 & Italy & 27,1 & 27,0 & 25,7 \\
\hline 12 & Japan & 11,2 & 11,1 & 10,8 \\
\hline 13 & Netherlands & 13,1 & 13,0 & 12,6 \\
\hline 14 & New Zealand & 12,8 & 12,6 & 12,3 \\
\hline 15 & Norway & 19,1 & 19,0 & 18,4 \\
\hline 16 & Portugal & 22,7 & 22,5 & 21,9 \\
\hline 17 & Spain & 22,7 & 22,5 & 22,0 \\
\hline 18 & Sweden & 19,2 & 19,1 & 18,3 \\
\hline 19 & Switzerland & 8,6 & 9,4 & 9,4 \\
\hline 20 & United Kingdom & 12,7 & 12,5 & 12,2 \\
\hline 21 & United States & 8,7 & 8,7 & 8,4 \\
\hline \multicolumn{2}{|c|}{ Unweighted Average } & 16,8 & 16,7 & 16,3 \\
\hline
\end{tabular}

If we first consider again the development of the size and development of the shadow economies of these 21 OECD countries, we realize for the first time that the size of the shadow economy of these 21 OECD countries has decreased over the period 1999/2000 to $2002 / 2003$. The average size of the shadow economy in 1999/2000 of these 21 OECD countries was $16.8 \%$ of official GDP, it decreased to $16.3 \%$ in $2002 / 2003$, a decrease of 0.5 percentage points. If we consider single countries, Greece, Italy and Spain has by far the largest size of the shadow economy in $2002 / 2003$ with $28.2 \%, 25.7 \%$ and $22.0 \%$ of official GDP. The median country is Ireland with $15.3 \%$, surrounded by Germany with $16.8 \%{ }^{25)}$ and Canada with $15.2 \%$ of official GDP. At the lower end are the United States, Switzerland and Japan with a shadow economy of $8.4 \%, 9.4 \%$ and $10.8 \%$ of official GDP.

\footnotetext{
25) Pickhardt and Sarda-Pous (2006) reach very similar values of the shadow economy for Germany using a combination of a MIMIC and Currency Demand Method.
} 


\subsubsection{South West Pacific Islands}

The size and development of the shadow economies of 10 South West Pacific islands is presented in table 3.2.6.

Table 3.2.6.: The Size of the Shadow Economy in 10 South West Pacific Islands

\begin{tabular}{|c|c|c|c|c|}
\hline & & $\begin{array}{r}\text { Shadol } \\
\text { DYN }\end{array}$ & $\begin{array}{l}\text { nomy (in \% of } \\
\text { and Currency }\end{array}$ & $\begin{array}{l}\text { DP) using the } \\
\text { nd Method }\end{array}$ \\
\hline & Country & $1999 / 00$ & $2001 / 02$ & $2002 / 03$ \\
\hline 1 & Fiji & 33,6 & 34,3 & 35,1 \\
\hline 2 & Kiribati & 34,1 & 35,0 & 35,3 \\
\hline 3 & Maldives & 30,3 & 31,4 & 32,0 \\
\hline 4 & Marshall Islands & 28,1 & 29,0 & 29,6 \\
\hline 5 & Micronesia, Fed. Sts. & 31,3 & 32,1 & 33,2 \\
\hline 6 & Palau & 28,4 & 29,2 & 30,0 \\
\hline 7 & Samoa & 31,4 & 32,6 & 33,5 \\
\hline 8 & Solomon Islands & 33,4 & 34,5 & 35,3 \\
\hline 9 & Tonga & 35,1 & 36,3 & 37,4 \\
\hline 10 & Vanuatu & 30,9 & 31,7 & 32,5 \\
\hline Un & weighted Average & 31,7 & 32,6 & 33,4 \\
\hline
\end{tabular}

If we again consider first the development over time the average size of the shadow economy of these 10 South West Pacific islands countries, increased from $31.7 \%$ in the year 1999/2000 to $33.4 \%$ in the year $2002 / 2003$, which means an increase of 1.7 percentage points over these four years. The largest size of the shadow economy (the latest estimation period 2002/2003) has Tonga with $37.4 \%$, followed by Solomon Islands with $35.3 \%$ and Kiribati with $35.3 \%$. In the middle field is Micronesia and Samoa with a shadow economy of $33.2 \%$ and $33.5 \%$ of official GDP. The lowest shadow economy have the Marshall Islands and Palau with a shadow economy of $29.6 \%$ and $30.0 \%$.

\subsubsection{Communist Countries}

In this last section the size and development of the shadow economy of 3 communist countries (China, Laos and Vietnam) is presented. The results are shown in table 3.2.7. 
Table 3.2.7: The Size of the Shadow Economy in 3 Communist Countries

\begin{tabular}{|c|c|c|c|c|}
\hline \multirow[b]{2}{*}{ No. } & \multirow[b]{2}{*}{ Country } & \multicolumn{3}{|c|}{$\begin{array}{l}\text { Shadow Economy (in \% of off. GDP) using the DYMIMIC and } \\
\text { Currency Demand Method }\end{array}$} \\
\hline & & $1999 / 00$ & 2001/02 & $2002 / 03$ \\
\hline 1 & China & 13,1 & 14,4 & 15,6 \\
\hline 2 & Lao PDR & 30,6 & 31,9 & 33,4 \\
\hline & Vietnam & 15,6 & 16,9 & 17,9 \\
\hline \multicolumn{2}{|c|}{ Unweighted Average } & 19,8 & 21,1 & 22,3 \\
\hline
\end{tabular}

If we again first consider the average development of the size of the shadow economy of these three Communist countries over time, the average size of the shadow economy in 1999/2000 was $19.8 \%$ and increased to $22.3 \%$ in $2002 / 2003$. This is an increase of 2.5 percentage points. Laos has the largest shadow economy with $33.4 \%$ and China the lowest with $15.6 \%$. It should be aware that the shadow economy in these countries, and especially in China, which is partly a market economy and still a planning socialist economy, is difficult to interpret. It should be more seen as a parallel economy, where especially farmers produce additional products to earn some extra money. It is an open question whether the meaning of these shadow economies can be compared to the size of the other ones. That is one reason, why they are shown in this paper in an extra section.

\section{Corruption and the Shadow Economy: Substitutes or Compliments? ${ }^{26)}$}

Theoretically, corruption and the shadow economy can be either complements or substitutes. Choi and Thum (2004) present a model where the option of entrepreneurs to go underground constrains a corrupt official's ability to ask for bribes. Dreher, Kotsogiannis and McCorriston (2005a,b) extend the model to the explicit specification of institutional quality. The model shows that corruption and shadow economy are substitutes in the sense that the existence of the shadow economy reduces the propensity of officials to demand grafts.

Johnson et al. (1998), to the contrary, model corruption and the shadow economy as complements. In their full-employment model, labour can be either employed in the official sector or in the underground economy. Consequently, an increase in the shadow economy 
always decreases the size of the official market. In their model, corruption increases the shadow economy, as corruption can be viewed as one particular form of taxation and regulation (driving entrepreneurs underground). Hindriks et al. (1999) also show that the shadow economy is a complement to corruption. This is because, in this case, the tax payer colludes with the inspector so the inspector underreports the tax liability of the tax payer in exchange for a bribe. ${ }^{27)}$

Theoretically, the relationship between corruption and the shadow economy is thus unsettled. There is, however, reason to believe that the relationship might differ among high and low income countries. In high income countries, the official sector provides public goods like the rule of law, enforcement of contracts, and protection by an efficient police. Usually, only craftsmen or very small firms have (or take) the option of going underground. In this case, the shadow economy is hidden from tax inspectors and other officials. In other words, there are no bribes necessary or possible to buy the way out of the official sector. In high income countries - typically showing comparably small levels of corruption - individuals confronted with a corrupt official always have the choice to bring the official to court. Moreover, in high income countries corruption quite often takes place, for example, to bribe officials to get a (huge) contract from the public sector (e.g. in the construction sector). This contract is then handled in the official economy and not in the shadow economy. Hence, corruption in high income countries can be a means to achieve certain benefits which make work in the official economy easier, e.g., winning a contract from a public authority, getting a licence (e.g. for operating taxes or providing other services or getting the permission to convert land into "construction ready" land, etc.). In high income countries people thus bribe in order to be able engaging in more official economic activities. As Schneider and Enste (2000) point out, at least two thirds of the income earned in the shadow economy is immediately spent in the official sector. The shadow economy and the official sector might thus be complements. The corresponding increase in government revenue and strengthened institutional quality is likely to decrease corruption. The prediction of a negative (substitutive) relation between corruption and the shadow economy is in line with the models of Choi and Thum (2004) and Dreher, Kotsogiannis and McCorriston (2005a). ${ }^{28}$ )

\footnotetext{
${ }^{26)}$ This section is taken from Dreher and Schneider (2006), pages 4, 5 and 14 as well as table 4.1.

${ }^{27)}$ See Dreher and Siemers (2005) for a formalization of this argument.

${ }^{28)}$ Consequently, Dreher, Kotsogiannis and McCorriston (2005a) test their model employing data for OECD countries only.
} 
In low income countries, to the contrary, we expect different mechanisms to prevail. Instead of working partly in the official sector and offering additional services underground as in high-income countries, enterprises completely engage in underground activity. Examples for enterprises operating completely underground are restaurants, bars, or haircutters - and even bigger production companies. As one reason for this, the public goods provided by the official sector are in many developing countries less efficient as compared to high income countries. Big companies, however, are comparably easy to detect and - in order to escape taxation and punishment - they have to bribe officials, thereby increasing corruption. Corruption often takes place in order to pay for activities in the shadow economy, so that the shadow economy entrepreneur can be sure not to be detected by public authorities. Here, shadow economy and corruption are likely to reinforce each other, as corruption is needed to expand shadow economy activities and - at the same time - underground activities require bribes and corruption. To get some additional income from the shadow economy entrepreneur, it is natural for public officials to ask for bribes and thus benefit from the shadow market. In low income countries, we therefore expect a positive (complementary) relation between corruption and the shadow economy. This corresponds to the predictions of the models of Hindriks et al. (1999) and Johnson et al. (1997).

In summary, following Dreher and Schneider (2006), I expect:

Hypothesis 1: In low income countries, shadow economy activities and corruption are complements.

Hypothesis 2: In high income countries, shadow economy activities and corruption are substitutes.

These two hypotheses are tested for a cross-section of 120 countries and a panel of 70 countries for the period 1994 to 2002. ${ }^{29)}$ Table 4.1 summarizes the empirical results of Dreher and Schneider (2006): Overall, they show that an increase in perceived corruption over time also increases the shadow economy. This confirms the models of Johnson et al. (1998) and Hindriks et al. (1999). Across countries, however, greater perceived corruption does not lead to a greater shadow economy. To some extent this also supports the results of Méon and Sekkat (2004) showing the within-country variation to be important in their analysis of corruption on foreign direct investment and exports.

${ }^{29}$ For the description of the data, the estimation techniques used, and the various specification see Dreher and 
Regarding the impact of the shadow economy on perceived corruption, these results for the overall sample are similar to those for the other way round. In the cross-country regressions, all coefficients are completely insignificant. An increase in the shadow economy over time increases corruption according to the fixed and random effects estimator, but not when the endogeneity of the shadow is controlled for. Turning to the sub-samples, the results show that higher perceived corruption significantly reduces the shadow economy in high income countries, confirming the models of Choi and Thum (2004) and Dreher, Kotsogiannis and McCorriston (2005a). In low income countries, to the contrary, corruption tends to increase with a higher shadow economy, again confirming the models of Johnson et al. (1998) and Hindriks et al. (1999). This is true for the impact of perceived corruption in the within-groups specification and actual corruption in all specifications. 
Table 4.1: Empirical Results of the Relationship between the Shadow Economy and Corruption

\begin{tabular}{|c|c|c|c|c|c|c|}
\hline \multirow{3}{*}{\begin{tabular}{|l|} 
Dependent Variable: \\
Independent Variable: \\
Estimation technique \\
\end{tabular}} & \multicolumn{3}{|c|}{ Shadow Economy } & \multicolumn{3}{|c|}{ Corruption } \\
\hline & \multicolumn{3}{|c|}{ Corruption } & \multicolumn{3}{|c|}{ Shadow Economy } \\
\hline & All & Low & High & All & Low & High \\
\hline \multicolumn{7}{|c|}{ ICRG index of corruption } \\
\hline OLS & $\begin{array}{c}1.88 \\
(1.20)\end{array}$ & $\begin{array}{c}3.57 \\
(1.34)\end{array}$ & $\begin{array}{l}-0,84 \\
(0.97)\end{array}$ & $\begin{array}{c}0.00 \\
(0.41)\end{array}$ & $\begin{array}{c}0.01 \\
(1.14)\end{array}$ & $\begin{array}{c}-0.07 \\
(3.57 * * *)\end{array}$ \\
\hline Robust regression & $\begin{array}{c}1.32 \\
(0.82) \\
\end{array}$ & - & - & $\begin{array}{c}0.00 \\
(0.43) \\
\end{array}$ & - & - \\
\hline IV, set 1 & $\begin{array}{c}3.72 \\
(1.17)\end{array}$ & $\begin{array}{c}3.12 \\
(0.86)\end{array}$ & $\begin{array}{c}5.41 \\
(1.40)\end{array}$ & $\begin{array}{l}-0.03 \\
(1.28)\end{array}$ & $\begin{array}{l}-0.01 \\
(0.42)\end{array}$ & $\begin{array}{l}-0.09 \\
(1.57)\end{array}$ \\
\hline IV, set 2 & $\begin{array}{l}-4.04 \\
(1.33)\end{array}$ & $\begin{array}{c}5.14 \\
(0.78)\end{array}$ & $\begin{array}{c}-1.85 \\
\left(1.91^{*}\right)\end{array}$ & $\begin{array}{l}-0.02 \\
(0.66)\end{array}$ & $\begin{array}{l}-0.02 \\
(0.46)\end{array}$ & $\begin{array}{l}-0.11 \\
(1.45)\end{array}$ \\
\hline Panel, fixed effects & $\begin{array}{c}1.34 \\
\left(2.63^{* *}\right)\end{array}$ & $\begin{array}{c}1.36 \\
(1.42)\end{array}$ & $\begin{array}{c}0.69 \\
(1.98 * *)\end{array}$ & $\begin{array}{c}\mathbf{0 . 0 9} \\
\left(2.88^{* * *}\right)\end{array}$ & $\begin{array}{c}\mathbf{0 . 1 0} \\
\left(2.77^{* * *}\right)\end{array}$ & $\begin{array}{c}0.09 \\
(0.76)\end{array}$ \\
\hline Panel, random effects & $\begin{array}{c}1.59 \\
\left(4.81^{* * *}\right)\end{array}$ & - & - & $\begin{array}{c}0.02 \\
(2.64 * * *)\end{array}$ & - & - \\
\hline Panel IV & $\begin{array}{c}3.46 \\
\left(3.48^{* * *}\right)\end{array}$ & - & - & $0.01(0.12)$ & - & - \\
\hline \multicolumn{7}{|l|}{ TI index of corruption } \\
\hline OLS & - & - & 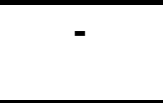 & 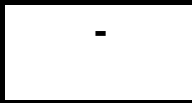 & 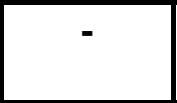 & $\begin{array}{c}-0.06 \\
\left(2.35^{* *}\right)\end{array}$ \\
\hline \multicolumn{7}{|c|}{ World Bank Index of corruption } \\
\hline OLS & - & 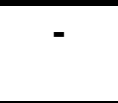 & 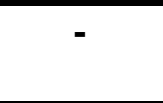 & 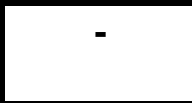 & 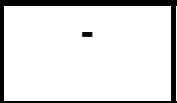 & $\begin{array}{c}-0.01 \\
\left(2.76^{* *}\right)\end{array}$ \\
\hline \multicolumn{7}{|c|}{ DKM index of corruption } \\
\hline OLS & 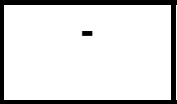 & 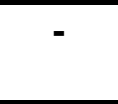 & 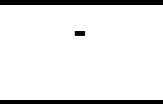 & $\begin{array}{c}0.04 \\
\left(1.77^{*}\right)\end{array}$ & $\begin{array}{c}0.06 \\
(2.49 * *)\end{array}$ & $\begin{array}{l}-0.10 \\
(1.50)\end{array}$ \\
\hline Robust regression & - & - & - & $\begin{array}{c}0.04 \\
(1.69 *) \\
\end{array}$ & - & - \\
\hline IV, set 1 & - & - & - & $\begin{array}{c}0.14 \\
\left(2.59^{* *}\right)\end{array}$ & $\begin{array}{c}0.10 \\
\left(2.65^{* *}\right)\end{array}$ & $\begin{array}{l}-0.32 \\
(1.22)\end{array}$ \\
\hline IV, set 2 & - & - & - & $\begin{array}{c}0.12 \\
\left(2.45^{* *}\right)\end{array}$ & $\begin{array}{c}0.12 \\
(2.50 * *)\end{array}$ & $\begin{array}{c}0.04 \\
(0.19)\end{array}$ \\
\hline
\end{tabular}

Notes:

Higher values represent more corruption; corruption indices used: ICRG International Country Risk Guide; TI=Transparency International; World Bank Index of Corruption; and DKM-Index of Dreher, Kotsogiannis and McCorriston.

Instruments for the shadow economy are: (1) Credit Market Regulations (Fraser), Minimum Wage Regulation (Fraser), Government Effectiveness (World Bank); (2) Starting a Business (Duration), Starting a Business (Costs), Flexibility to Hire, Flexibility to Fire.

Instruments for corruption are: (1) Fiscal Burden (Heritage), Regulation of Prices (Fraser), Rule of Law (World Bank), Democracy; (2) Ethnic Fractionalization, Religious Fractionalization, Latitude, French Legacy, Socialist Legacy, German Legacy, Scandinavian Legacy.

* denotes significant at $10 \%$ level; ** significant at $5 \%$ level; *** significant at $1 \%$ level

Source: Dreher and Schneider (2006, table 12). 


\section{Summary and Conclusions}

There have been many obstacles to overcome to measure the size of the shadow economy, to analyze its consequences on the official economy and the interaction between corruption and the shadow economy, but as this paper shows some progress has been made. I provided estimates of the size of the shadow economies for 145 countries for three periods of time (1999/2000, 2001/2002 and 2002/2003) using the DYMIMIC and the currency demand approach. Coming back to the question in the headline of this paper, some (new) knowledge/insights are gained with respect to the size and development of the shadow economy of developing, transition, highly developed OECD, Pacific Islands and Communist countries, ${ }^{30)}$ and to the relationship between the shadow economy and corruption leading to five conclusions:

The first conclusion from these results is that for all countries investigated the shadow economy has reached a remarkably large size; the summarized results are shown in table 5.1.

Table 5.1: Average Size of the Shadow Economy for Developing, Transition and OECDCountries in \% of official GDP

\begin{tabular}{|c|c|c|c|}
\hline Countries/Year & \multicolumn{3}{|c|}{$\begin{array}{c}\text { Average Size of the Shadow Economy - Value added in \% of } \\
\text { official GDP using DYMIMIC and Currency Demand } \\
\text { method (Number of Countries) }\end{array}$} \\
\hline Mostly developing countries: & $1999 / 2000$ & $2000 / 2001$ & $2002 / 2003$ \\
\hline $\begin{array}{l}\text { Africa } \\
\text { Central and South America } \\
\text { Asia }\end{array}$ & $\begin{array}{l}41.3 \\
(37) \\
41.1 \\
(21) \\
28.5 \\
(28)\end{array}$ & $\begin{array}{l}42.3 \\
(37) \\
42.1 \\
(21) \\
29.5 \\
(28)\end{array}$ & $\begin{array}{l}43.2 \\
(37) \\
43.4 \\
(21) \\
30.4 \\
(28)\end{array}$ \\
\hline Transition countries & $\begin{array}{l}38.1 \\
(25)\end{array}$ & $\begin{array}{l}39.1 \\
(25)\end{array}$ & $\begin{array}{l}40.1 \\
(25)\end{array}$ \\
\hline $\begin{array}{l}\text { Highly developed OECD } \\
\text { Countries }\end{array}$ & $\begin{array}{l}16.8 \\
(21)\end{array}$ & $\begin{array}{l}16.7 \\
(21)\end{array}$ & $\begin{array}{l}16.3 \\
(21)\end{array}$ \\
\hline South Pacific Islands & $\begin{array}{l}31.7 \\
(10)\end{array}$ & $\begin{array}{l}32.6 \\
(10)\end{array}$ & $\begin{array}{l}33.4 \\
(10)\end{array}$ \\
\hline Communist Countries & $\begin{array}{c}19.8 \\
(3)\end{array}$ & $\begin{array}{c}21.1 \\
(3)\end{array}$ & $\begin{array}{c}22.3 \\
(3)\end{array}$ \\
\hline $\begin{array}{l}\text { Unweighted Average over } 145 \\
\text { Countries }\end{array}$ & 33.6 & 34.5 & 35.2 \\
\hline
\end{tabular}

Source: Own calculations.

\footnotetext{
${ }^{30)}$ In the appendix some critical discussion of these two methods is given, they have well known weaknesses, compare also Pedersen (2003).
} 
The second conclusion is, shadow economies are a complex phenomenon, present to an important extent in all type of economies (developing, transition and highly developed). People engage in shadow economic activity for a variety of reasons, among most important, of which we can count are government actions, most notable taxation and regulation. With these two insights/conclusions goes a third, no less important one: a government aiming to decrease shadow economic activity has to first and foremost analyze the complex relationships between the official and shadow economy - and even more important - among consequences of its own policy decisions.

Considering a public choice perspective a fourth conclusion for highly developed countries is, that a government may not have a great interest to reduce the shadow economy due to the facts, that

(i) tax losses my be moderate, as at least $2 / 3$ of the the income earned in the shadow economy is immediately spend in the official economy,

(ii) income earned in the shadow economy increases the standard of living at least of $1 / 3$ of the working population, and

(iii) people who work in the shadow economy have less time for other things like to go on demonstrations, etc.

Considering these three facts, it is obvious, that one of the big challenges for every government is to undertake efficient incentive orientated policy measures in order to make work less attractive in the shadow economy and hence to make the work in the official economy more attractive. In a number of OECD countries this policy direction has been successfully implemented and this has lead to a reduction of the shadow economy.

A final and fifth conclusion is, that the results of the empirical analysis of Dreher and Schneider (2006) suggest that corruption and the shadow economy tend to be substitutes in high income countries, but complements in low income countries. There is thus some support for their hypotheses ( 1 and 2 ). The analysis also shows, however, that the results do to some extent depend on the method of estimation. 


\section{Appendix 1: Methods to Estimate the Size of the Shadow Economy}

As has already been mentioned in chapters 2 and 3 estimating the size and development of a shadow economy is a difficult and challenging task. In this appendix I give a short but comprehensive overview on the various procedures to estimate the size of a shadow economy. Three different types of methods are most widely used, and each is briefly discussed as well as critically evaluated.

\subsection{Direct Approaches}

\subsubsection{Survey Method}

These are micro approaches that employ either well designed surveys and samples based on voluntary replies or tax auditing and other compliance methods. Sample surveys designed to estimate the shadow economy are widely used in a number of countries ${ }^{31)}$. The main disadvantage of this method is that it presents the flaws of all surveys. For example, the average precision and results depend greatly on the respondent's willingness to cooperate, it is difficult to asses the amount of undeclared work from a direct questionnaire, most interviewers hesitate to confess a fraudulent behavior, and responses are of uncertain reliability, which makes it difficult to calculate a real estimate (in monetary terms) of the extend of undeclared work. The main advantage of this method lies in the detailed information about the structure of the shadow economy, but the results from these kinds of surveys are very sensitive to the way the questionnaire is formulated ${ }^{32)}$.

In order to demonstrate the difficulties to calculate a macro estimation for a whole country from survey results of shadow economy activities (from single individuals) the following example is used. In Austria the author undertook a representative questioning of the Austrian population in order to estimate the size of the shadow economy in the construction an

\footnotetext{
${ }^{31)}$ The direct method of voluntary sample surveys has been extensively used for Norway by Isachsen, Klovland and Strom (1982), and Isachsen and Strom (1985). For Denmark this method is used by Mogensen et. al. (1995) in which they report „estimates“ of the shadow economy of 2.7 percent of GDP for 1989, of 4.2 percent of GDP for 1991, of 3.0 percent of GDP for 1993 and of 3.1 percent of GDP for 1994. In Pedersen (2003) estimates of the Danish shadow economy contain the years 1995 with $3.1 \%$ up to 2001 with $3.8 \%$.

${ }^{32)}$ The advantages and disadvantages of this method are extensively dealt by Pedersen (2003), Mogensen et. al (1995) and Feld and Larsen (2005) in their excellent and very carefully done investigations. Compare also the careful and detailed studies by Kazemier (2005a,b), who extensitively discusses the pros .and cons of this method.
} 
craftsman sector (including repairing) in November /December 2002 considering three groups.

1. A representative sample of the Austrian population between 16 and 65 years old.

2. 55 self declared shadow economy workers in the construction and craftsmen sector, and

3. 320 managers (owners) of construction and craftsmen firms.

The following results were gained: (1) Among the Austrian population (potential labour force) are 918.000 Austrians who supplied shadow economy activities in the construction and craftsmen sector. They average hourly earning in the shadow economy varies between $€ 15,30$ and $€ 15,60$, and the average yearly income from shadow economy activities varies between $€$ 1.117 ,- and $€ 1.142$,-. This means that 73 hours per year were worked in the shadow economy. (2) Among the 55 self-declared shadow economy workers I got a wage rate of $€ 11,50$ per hour and an earning per year in the shadow economy was $€ 2.480$,- using the fact, that these group worked 245 hours per year in the shadow economy.

(3) Managers (owners) of construction and craftsmanship firms report a wage rate of shadow economy workers of $€ 17$,- per hour and an average earning per year from $€ 4.590$,-, assuming that 270 hours per year were used for shadow economy activities by their employees/workers. The questioned managers also state: $21 \%$ that more then $50 \%$ of their employees work in the shadow economy, $41 \%$ that less then $50 \%$, and $34 \%$ that no-one in the firm works in the shadow economy. To summarize $62 \%$ of the managers acknowledge that a large percentage of their employees work in the shadow economy. Further results are, that $7 \%$ of the managers think, that their employees work between 0 and 2 hours per week in the shadow economy; 29 $\%$ assume that they work between 6 and 10 hours, 28\% between 3 and 5 hours and 14\% think that their employees work more then 10 hours per week in the shadow economy; $22 \%$ of all managers have no knowledge of this fact. In principle 39\% of managers are not in favour (do not support), that their workers moonlight and $61 \%$ are in favour (do support) - an amazing high percentage.

Finally in the table 6.1 the aggregate values of the size of the shadow economy in the construction and craftsmen sector of the year 2002 based on questionnaire findings are presented. Table 6.1 clearly demonstrates, that the size of the shadow economy in the construction an craftsmen sector varies considerably from a total value of 2.6 billion Euros up to 4.2 billion Euros. These differences origin from different hourly wages rates, ranging from $11,50 €$ to $17 €$ and from the different amount of hours worked per year in the shadow economy ranging from $245 \mathrm{~h}$ to $270 \mathrm{~h}$. Hence the survey method "covers" between $31,2 \%$ and 
$50,9 \%$ of the value obtained by a macro approach (mimic method). These results leave still open a considerable leeway, but the rather large differences may be explained due to the following facts:

1. Table 6.1 contains earnings and not the value added of the shadow economy.

2. Shadow economy demanders are overwhelmingly households, the whole area of the shadow economy activities between firms (which are especially a problem in the construction and craftsmen sectors) are not considered.

3. All foreign shadow economy activities achieved by foreigners (illegal immigrants) is not considered.

4. The amount earned in the shadow economy, hourly wage rate and hours worked per year vary considerably. 
Table 6.1: Size of the supplied shadow economy in the construction and craftsmen sector, Austria 2002, based on the questionnaire findings

\begin{tabular}{|c|c|c|c|c|}
\hline \multirow[b]{2}{*}{ Variable/Indicator } & \multicolumn{4}{|c|}{ Worked hours and earning in the shadow economy } \\
\hline & $\begin{array}{l}\text { results from } \\
\text { declared } \\
\text { moonlighters } \\
\text { (1) }\end{array}$ & $\begin{array}{l}\text { results from } \\
\text { managers of } \\
\text { construction } \\
\text { and craftsmen } \\
\text { firms } \\
(2) \\
\end{array}$ & $\begin{array}{l}\text { results from } \\
\text { declared } \\
\text { moonlighters } \\
\text { (3) }\end{array}$ & $\begin{array}{l}\text { results from managers } \\
\text { of construction and } \\
\text { craftsmen firms } \\
\text { (4) }\end{array}$ \\
\hline $\begin{array}{l}\varnothing \text { hourly shadow } \\
\text { economy wage rate }\end{array}$ & $11.5 €$ & $17 €$ & $11.5 €$ & $17 €$ \\
\hline $\begin{array}{l}\varnothing \text { average yearly } \\
\text { earning }\end{array}$ & $2,814 €$ & $4,165 €$ & $3,105 €$ & $4,590 €$ \\
\hline $\begin{array}{l}\varnothing \text { amount of hours } \\
\text { worked in the shadow } \\
\text { economy per year per } \\
\text { worker }\end{array}$ & $245 \mathrm{~h}$ & $245 \mathrm{~h}$ & $270 \mathrm{~h}$ & $270 \mathrm{~h}$ \\
\hline $\begin{array}{l}\varnothing \text { aggregated yearly } \\
\text { amount of million } \\
\text { hours worked in the } \\
\text { shadow economy } 1 \text { ) }\end{array}$ & 225.1 Mio. $h$ & 225.1 Mio. $h$ & 248.1 Mio. $\mathrm{h}$ & 248.1 Mio. $\mathrm{h}$ \\
\hline $\begin{array}{l}\text { Total earnings of the } \\
\text { shadow economy in } \\
\text { the year } 2002\end{array}$ & 2,588.65 Mio. $€$ & 3,826.7 Mio. $€$ & 2,853.15 Mio. $€$ & 4,217.7 Mio. $€$ \\
\hline 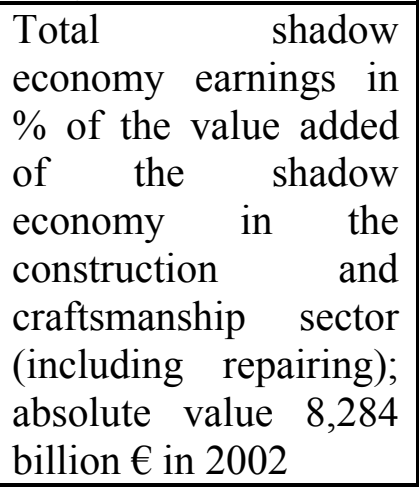 & $31,2 \%$ & $46,1 \%$ & $34,4 \%$ & $50,9 \%$ \\
\hline
\end{tabular}

1) Basis of the calculation 918,864 shadow economy workers in the construction and craftsmen sector. Source: Own calculations.

\subsubsection{Tax Auditing Method}

Estimates of the shadow economy can also be based on the discrepancy between income declared for tax purposes and that measured by selective checks. Fiscal auditing programs have been particularly effective in this regard. Since these programs are designed to measure the amount of undeclared taxable income, they may also be used to calculate the shadow 
economy. ${ }^{33)}$ However, a number of difficulties beset this approach. First, using tax compliance data are equivalent to using a (possibly biased) sample of the population. In general, the selection of tax payers for tax audit is not random but based on properties of submitted ( $\operatorname{tax})$ returns that indicate a certain likelihood of (tax) fraud. Consequently, such a sample is not a random one of the whole population, and estimates of the shadow based upon a biased sample may not be accurate. Second estimates based on tax audits reflect only that portion of shadow economy income that the authorities succeed in discovering, and this is likely to be only a fraction of hidden income.

A further disadvantage of these two direct methods (surveys and tax auditing) is that they lead only to point estimates. Moreover, it is unlikely that they capture all „shadow“ activities, so they can be seen as providing lower bound estimates. They are unable to provide estimates of the development and growth of the shadow economy over a longer period of time. As already argued, they have, however at least one considerable advantage - they can provide detailed information about shadow economy activities and the structure and composition of those who work in the shadow economy.

\subsection{Indirect Approaches}

These approaches, which are also called ,indicator“ approaches, are mostly macroeconomic ones and use various economic and other indicators that contain information about the development of the shadow economy (over time). Currently there are five indicators that leave some „traces“ of the shadow economy.

\subsubsection{The Discrepancy between National Expenditure and Income Statistics}

This approach is based on discrepancies between income and expenditure statistics. In national accounting the income measure of GNP should be equal to the expenditure measure of GNP. Thus, if an independent estimate of the expenditure site of the national accounts is available, the gap between the expenditure measure and the income measure can be used as an indicator of the extent of the black economy. ${ }^{34)}$ Since national accounts statisticians are

\footnotetext{
${ }^{33)}$ In the United States, IRS (1979, 1983), Simon and Witte (1982), Witte (1987), Clotefelter (1983), and Feige (1986). For a more detailed discussion, see Dallago (1990) and Thomas (1992).

34) See, e.g., Franz (1983) for Austria; MacAfee (1980) O'Higgins (1989) and Smith (1985), for Great Britain; Petersen (1982) and Del Boca (1981) for Germany; Park (1979) for the United States. For a critical survey, see Thomas (1992).
} 
anxious to minimize this discrepancy, the initial discrepancy or first estimate, rather than the published discrepancy should be employed as an estimate of the shadow economy. If all the components of the expenditure site are measured without error, then this approach would indeed yield a good estimate of the scale of the shadow economy. Unfortunately, however, this is not the case. Instead, the discrepancy reflects all omissions and errors everywhere in the national accounts statistics as well as the shadow economy activity. These estimates may therefore be very crude and of questionable reliability. ${ }^{35)}$

\subsubsection{The Discrepancy between the Official and Actual Labor Force}

A decline in participation of the labor force in the official economy can be seen as an indication of increased activity in the shadow economy. If total labor force participation is assumed to be constant, than a decreasing official rate of participation can be seen as an indicator of an increase in the activities in the shadow economy, ceteris paribus. ${ }^{36)}$ One weakness of this method is that differences in the rate of participation may also have other causes. Also, people can work in the shadow economy and have a job in the „official' economy. Therefore such estimates may be viewed as weak indicators of the size and development of the shadow economy.

\subsubsection{The Transactions Approach}

This approach has been most fully developed by Feige. ${ }^{37)}$ It is based upon the assumption, that there is a constant relation over time between the volume of transaction and official GNP, as summarized by the well-known Fisherian quantity equation, or $M^{*} V=p^{*} T$ (with $M=$ money, $\mathrm{V}=$ velocity, $\mathrm{p}=$ prices, and $\mathrm{T}=$ total transactions). Assumptions also have to be made about the velocity of money and about the relationships between the value of total transactions $\left(\mathrm{p}^{*} \mathrm{~T}\right)$ and total (=official + unofficial) nominal GNP. Relating total nominal GNP to total transactions, the GNP of the shadow economy can be calculated by subtracting the official GNP from total nominal GNP. However, to derive figures for the shadow economy, one must also assume a base year in which there is no shadow economy and

\footnotetext{
${ }^{35)}$ A related approach is pursued by Pissarides and Weber (1988), who use micro data from household budget surveys to estimate the extend of income understatement by self-employed.

${ }^{36)}$ Such studies have been made for Italy, see e.g., Contini (1981) and Del Boca (1981); for the United States, see O'Neill (1983), for a critical survey, see again Thomas (1992).

${ }^{37)}$ For an extended description of this approach, see Feige (1996); for a further application for the Netherlands, Boeschoten and Fase (1984), and for Germany, Langfeldt (1984).
} 
therefore the ratio of $\mathrm{p}^{* \mathrm{~T}}$ to total nominal (official = total) GNP was „normal“ and would have been constant over time, if there had been no shadow economy.

This method, too, has several weaknesses, such as the required assumptions of a base year with no shadow economy, and of a „normal“ ratio of transactions to nominal GNP. Moreover, to obtain reliable shadow economy estimates, precise figures of the total volume of transactions should be available, and this availability might be especially difficult to achieve for cash transactions, because they depend, among other factors, on the durability of bank notes in terms of the quality of the papers on which they are printed. ${ }^{38)}$ Also, the assumption is made that all variations in the ratio between the total value of transaction and the officially measured GNP are due to the shadow economy. This means that a considerable amount of data is required in order to eliminate financial transactions from "pure" cross payments, which are legal and have nothing to do with the shadow economy. In general, although this approach is theoretically attractive, the empirical requirements necessary to obtain reliable estimates are so difficult to fulfill, that its application may lead to doubtful results.

\subsubsection{The Currency Demand Approach}

The currency demand approach was first used by Cagan (1958), who calculated a correlation of the currency demand and the tax pressure (as one cause of the shadow economy) for the United States over the period 1919 to 1955. 20 years later, Gutmann (1977) used the same approach but without any statistical procedures. Cagan's approach was further developed by Tanzi (1980, 1983), who econometrically estimated a currency demand function for the United States for the period 1929 to 1980 in order to calculate the shadow economy. His approach assumes that shadow (or hidden) transactions are undertaken in the form of cash payments, so as to leave no observable traces for the authorities. An increase in the size of the shadow economy will therefore increase the demand for currency. To isolate the resulting „excess“ demand for currency, an equation for currency demand is econometrically estimated over time. All conventional possible factors, such as the development of income, payment habits, interest rates, and so on, are controlled for. Additionally, such variables as the direct and indirect tax burden, government regulation and the complexity of the tax system, which are assumed to be the major factors causing people to work in the shadow economy, are

\footnotetext{
${ }^{38)}$ For a detailed criticism of the transaction approach see Boeschoten and Fase (1984), Frey and Pommerehne (1984), Kirchgaessner (1984), Tanzi (1982a,b, 1986), Dallago (1990), Thomas (1986, 1992, 1999), Giles (1999a), Pederson (2003), and Janisch and Brümmerhoff (2005) and Breusch (2005a, 2005b).
} 
included in the estimation equation. The basic regression equation for the currency demand, proposed by Tanzi (1983), is the following:

$\ln \left(\mathrm{C} / \mathrm{M}_{2}\right)_{\mathrm{t}}=\beta_{\mathrm{O}}+\beta_{1} \ln (1+\mathrm{TW})_{\mathrm{t}}+\beta_{2} \ln (\mathrm{WS} / \mathrm{Y})_{\mathrm{t}}+\beta_{3} \ln \mathrm{R}_{\mathrm{t}}+\beta_{4} \ln (\mathrm{Y} / \mathrm{N})_{\mathrm{t}}+\mathrm{u}_{\mathrm{t}}$ with $\beta_{1}>0, \beta_{2}>0, \beta_{3}<0, \beta_{4}>0$

where

In denotes natural logarithms,

$\mathrm{C} / \mathrm{M}_{2}$ is the ratio of cash holdings to current and deposit accounts,

TW is a weighted average tax rate (to proxy changes in the size of the shadow economy),

$\mathrm{WS} / \mathrm{Y}$ is a proportion of wages and salaries in national income (to capture changing payment and money holding patterns),

$\mathrm{R}$ is the interest paid on savings deposits (to capture the opportunity cost of holding cash) and $\mathrm{Y} / \mathrm{N}$ is the per capita income. ${ }^{39)}$

Any „excess“ increase in currency, or the amount unexplained by the conventional or normal factors (mentioned above) is then attributed to the rising tax burden and the other reasons leading people to work in the shadow economy. Figures for the size and development of the shadow economy can be calculated in a first step by comparing the difference between the development of currency when the direct and indirect tax burden (and government regulations) are held at its lowest value, and the development of currency with the current (much higher) burden of taxation and government regulations. Assuming in a second step the same income velocity for currency used in the shadow economy as for legal M1 in the official economy, the size of the shadow can be computed and compared to the official GDP.

The currency demand approach is one of the most commonly used approaches. It has been applied to many OECD countries, ${ }^{40)}$ but has nevertheless been criticized on various grounds. ${ }^{41)}$ The most commonly raised objections to this method are several:

\footnotetext{
39) The estimation of such a currency demand equation has been criticized by Thomas (1999) but part of this criticism has been considered by the work of Giles (1999a,b) and Bhattacharyya (1999), who both use the latest econometric technics.

${ }^{40)}$ See Karmann (1986 and 1990), Schneider (1997, 1998a), Johnson, Kaufmann and Zoido-Lobatón (1998a), and Williams and Windebank (1995).

${ }^{41)}$ See Thomas (1992, 1999), Feige (1986), Pozo (1996), Pedersen (2003) and Ahumada, Alvareda, Canavese A. and P. Canavese (2004). 
(i) Not all transactions in the shadow economy are paid in cash. Isachsen and Strom (1985) used the survey method to find out that in Norway, in 1980, roughly 80 percent of all transactions in the hidden sector were paid in cash. The size of the total shadow economy (including barter) may thus be even larger than previously estimated.

(ii) Most studies consider only one particular factor, the tax burden, as a cause of the shadow economy. But others (such as the impact of regulation, taxpayers' attitudes toward the state, „tax morality“ and so on) are not considered, because reliable data for most countries is not available. If, as seems likely, these other factors also have an impact on the extent of the hidden economy, it might again be higher than reported in most studies. $^{42)}$

(iii) As discussed by Garcia (1978), Park (1979), and Feige (1996), increases in currency demand deposits are due largely to a slowdown in demand deposits rather than to an increase in currency caused by activities in the shadow economy, at least in the case of the United States.

(iv) Blades (1982) and Feige (1986, 1996), criticize Tanzi's studies on the grounds that the US dollar is used as an international currency. Instead, Tanzi should have considered (and controlled for) the presence of US dollars, which are used as an international currency and held in cash abroad. ${ }^{43)}$ Moreover, Frey and Pommerehne (1984) and Thomas (1986, 1992, 1999) claim that Tanzi’s parameter estimates are not very stable. $^{44)}$

(v) Most studies assume the same velocity of money in both types of economies. As argued by Hill and Kabir (1996) for Canada and by Klovland (1984) for the Scandinavian countries, there is already considerable uncertainty about the velocity of

\footnotetext{
${ }^{42)}$ One (weak) justification for the only use of the tax variable is that this variable has by far the strongest impact on the size of the shadow economy in the studies known to the authors. The only exception is the study by Frey and Weck-Hannemann (1984) where the variable „tax immorality“ has a quantitatively larger and statistically stronger influence than the direct tax share in the model approach. In the study of Pommerehne and Schneider (1985), for the U.S., besides various tax measures, data for regulation, tax immorality, minimum wage rates are available, the tax variable has a dominating influence and contributes roughly 60-70 percent to the size of the shadow economy. See also Zilberfarb (1986).

43) In another study by Tanzi (1982, esp. pp. 110-113) he explicitly deals with this criticism. A very careful investigation of the amount of US-\$ used abroad and the US currency used in the shadow economy and to "classical" crime activities has been undertaken by Rogoff (1998), who concludes that large denomination bills are major driving force for the growth of the shadow economy and classical crime activities due largely to reduced transactions costs.

44) However in studies for European countries Kirchgaessner (1983, 1984) and Schneider (1986) reach the conclusion that the estimation results for Germany, Denmark, Norway and Sweden are quite robust when using the currency demand method. Hill and Kabir (1996) find for Canada that the rise of the shadow economy varies with respect to the tax variable used; they conclude ,when the theoretically best tax rates are selected and a range of plausible velocity values is used, this method estimates underground economic growth between 1964 and 1995 at between 3 and 11 percent of GDP.“" (Hill and Kabir [1996, p. 1553]).
} 
money in the official economy, and the velocity of money in the hidden sector is even more difficult to estimate. Without knowledge about the velocity of currency in the shadow economy, one has to accept the assumption of an „equal“ money velocity in both sectors.

(vi) Ahumada, Alvaredo, Canavese A. and P. Canavese (2004) show, that the currency approach together with the assumption of equal income velocity of money in both, the reported and the hidden transaction is only correct, if the income elasticity is 1 . As this is for most countries not the case, the calculation has to be corrected.

(vii) Finally, the assumption of no shadow economy in a base year is open to criticism. Relaxing this assumption would again imply an upward adjustment of the size of the shadow economy.

\subsubsection{The Physical Input (Electricity Consumption) Method}

\section{(1) The Kaufmann - Kaliberda Method ${ }^{45)}$}

To measure overall (official and unofficial) economic activity in an economy, Kaufmann and Kaliberda (1996) assume that electric-power consumption is regarded as the single best physical indicator of overall (or official plus unofficial) economic activity. Now, overall economic activity and electricity consumption have been empirically observed throughout the world to move in lockstep with an electricity to GDP elasticity usually close to one. This means, that the growth of total electricity consumption is an indicator for growth of overall (official and unofficial) GDP. By having this proxy measurement for the overall economy and then subtracting from this overall measure the estimates of official GDP, Kaufmann and Kaliberda (1996) derive an estimate of unofficial GDP. This method is very simple and appealing. However, it can also be criticized on various grounds:

(i) Not all shadow economy activities require a considerable amount of electricity (e.g. personal services), and other energy sources can be used (gas, oil, coal, etc.). Only a part of the shadow economy will be captured.

(ii) Over time, there has been considerable technical progress, so that both the production and use of electricity are more efficient than in the past, and this will apply in both official and unofficial uses.

\footnotetext{
${ }^{45)}$ This method was used earlier by Lizzeri (1979), Del Boca and Forte (1982), and then was used much later by Portes (1996), Kaufmann and Kaliberda (1996), Johnson, Kaufmann and Shleifer (1997). For a critique see Lackó (1998).
} 
(iii) There may be considerable differences or changes in the elasticity of electricity/GDP across countries and over time. ${ }^{46)}$

\section{(2) The Lackó Method}

Lackó $(1996,1998,1999,2000)$ assumes that a certain part of the shadow economy is associated with the household consumption of electricity. This part comprises the so-called household production, do-it-yourself activities, and other non registered production and services. Lackó further assumes that in countries where the portion of the shadow economy associated with the household electricity consumption is high, the rest of the hidden economy (or the part Lackó cannot measure) will also be high. Lackó (1996, pp.19 ff.) assumes that in each country a part of the household consumption of electricity is used in the shadow economy.

Lackó's approach (1998, p.133) can be described by the following two equations:

$\ln \mathrm{E}_{\mathrm{i}}=\alpha_{1} \ln \mathrm{C}_{\mathrm{i}}+\alpha_{2} \ln \mathrm{PR}_{\mathrm{i}}+\alpha_{3} \mathrm{G}_{\mathrm{i}}+\alpha_{4} \mathrm{Q}_{\mathrm{i}}+\alpha_{5} \mathrm{H}_{\mathrm{i}}+\mathrm{u}_{\mathrm{i}}$

with $\quad \alpha_{1}>0, \alpha_{2}<0, \alpha_{3}>0, \alpha_{4}<0, \alpha_{5}>0$

$\mathrm{H}_{\mathrm{i}} \quad=\beta_{1} \mathrm{~T}_{\mathrm{i}}+\beta_{2}\left(\mathrm{~S}_{\mathrm{i}}-\mathrm{T}_{\mathrm{i}}\right)+\beta_{3} \mathrm{D}_{\mathrm{i}}$

with $\beta_{1}>0, \beta_{2}<0, \beta_{3}>0$

where

$\mathrm{i}$ : the number assigned to the country,

$E_{i}$ : per capita household electricity consumption in country $i$ in Mtoe,

$\mathrm{C}_{\mathrm{i}}$ : per capita real consumption of households without the consumption of electricity in country $\mathrm{i}$ in US dollars (at purchasing power parity),

$\mathrm{PR}_{\mathrm{i}}$ : the real price of consumption of $1 \mathrm{kWh}$ of residential electricity in US dollars (at purchasing power parity),

$\mathrm{G}_{\mathrm{i}}$ : the relative frequency of months with the need of heating in houses in country $i$,

$\mathrm{Q}_{\mathrm{i}}$ : the ratio of energy sources other than electricity energy to all energy sources in household energy consumption,

$\mathrm{H}_{\mathrm{i}}$ : the per capita output of the hidden economy,

$\mathrm{T}_{\mathrm{i}}$ : the ratio of the sum of paid personal income, corporate profit and taxes on goods and services to GDP,

$\mathrm{S}_{\mathrm{i}}$ : the ratio of public social welfare expenditures to GDP, and

\footnotetext{
${ }^{46)}$ Johnson, Kaufmann and Shleifer (1997) make an attempt to adjust for changes in the elasticity of electricity/GDP.
} 
$\mathrm{D}_{\mathrm{i}}$ : the sum on number of dependants over 14 years and of inactive earners, both per 100 active earners.

In a cross country study, she econometrically estimates equation (1) substituting $\mathrm{H}_{\mathrm{i}}$ by equation (2). The econometric estimation results can then be used to establish an ordering of the countries with respect to electricity use in their respective shadow economies. For the calculation of the actual size (value added) of the shadow economy, Lackó further must know how much GDP is produced by one unit of electricity in the shadow economy of each country. Since these data are not known, she takes the result of one of the known shadow economy estimations, that were carried out for a market economy with another approach for the early 1990s, and she applies this proportion to the other countries. Lackó used the shadow economy of the United States as such a base (the shadow economy value of $10.5 \%$ of GDP taken from Morris(1993)), and then she calculates the size of the shadow economy for other countries. Lackó's method is also open to criticism:

(i) Not all shadow economy activities require a considerable amount of electricity and other energy sources can be used.

(ii) Shadow economy activities do not take place only in the household sector.

(iii) It is doubtful whether the ratio of social welfare expenditures can be used as the explanatory factor for the shadow economy, especially in transition and developing countries.

It is questionable which is the most reliable base value of the shadow economy in order to calculate the size of the shadow economy for all other countries, especially, for the transition and developing countries.

\subsection{The Model Approach ${ }^{47}$}

All methods described so far that are designed to estimate the size and development of the shadow economy consider just one indicator that "must" capture all effects of the shadow economy. However, it is obvious that shadow economy effects show up simultaneously in the production, labor, and money markets. An even more important critique is that the causes that

\footnotetext{
${ }^{47)}$ This summary is derived from a longer study by Aigner, Schneider, and Ghosh (1988, p. 303), applying this approach for the United States over time; for Germany this approach has been applied by Karmann (1986 and 1990). The pioneers of this approach are Weck (1983), Frey and Weck-Hannemann (1984), who applied this approach to cross-section data from the 24 OECD countries for various years. Before turning to this approach they developed the concept of „soft modeling“ (Frey, Weck, and Pommerehne (1982), Frey and Weck (1983a and 1983b)), an approach which has been used to provide a ranking of the relative size of the shadow economy
} 
determine the size of the shadow economy are taken into account only in some of the monetary approach studies that usually consider one cause, the burden of taxation. The model approach explicitly considers multiple causes leading to the existence and growth of the shadow economy, as well as the multiple effects of the shadow economy over time.

The empirical method used is quite different from those used so far. It is based on the statistical theory of unobserved variables, which considers multiple causes and multiple indicators of the phenomenon to be measured. For the estimation, a factor-analytic approach is used to measure the hidden economy as an unobserved variable over time. The unknown coefficients are estimated in a set of structural equations within which the "unobserved" variable cannot be measured directly. The DYMIMIC (dynamic multiple-indicators multiplecauses) model consists in general of two parts, with the measurement model linking the unobserved variables to observed indicators. ${ }^{48)}$ The structural equations model specifies causal relationships among the unobserved variables. In this case, there is one unobserved variable, or the size of the shadow economy; this is assumed to be influenced by a set of indicators for the shadow economy's size, thus capturing the structural dependence of the shadow economy on variables that may be useful in predicting its movement and size in the future. The interaction over time between the causes $Z_{i t}(i=1,2, \ldots, k)$ the size of the shadow economy $X_{t}$, in time $t$ and the indicators $Y_{j t}(j=1,2, \ldots, p)$ is shown in Figure 6.1.

Figure 6.1: Development of the shadow economy over time.

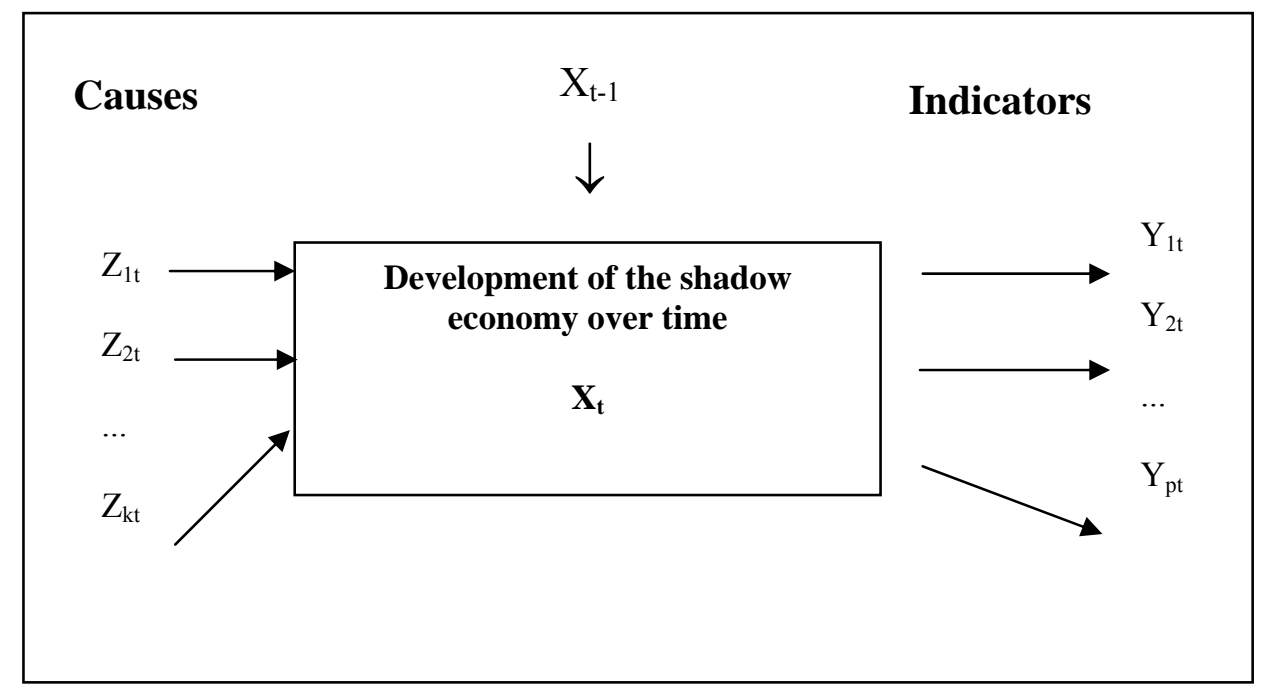

in different countries.

48) The latest papers dealing extensively with the DYMIMIC or MIMIC approach, its development and its weaknesses is from Del'Anno (2003) and the excellent study by Giles and Tedds (2002), as well as Breusch (2005a, 2005b), and Pickhardt and Sarda-Pous (2006). 
There is a large body of literature ${ }^{49}$ ) on the possible causes and indicators of the shadow economy, in which the following three types of causes are distinguished:

\section{Causes}

(i) The burden of direct and indirect taxation, both actual and perceived. A rising burden of taxation provides a strong incentive to work in the shadow economy.

(ii) The burden of regulation as proxy for all other state activities. It is assumed that increases in the burden of regulation give a strong incentive to enter the shadow economy.

(iii) The „tax morality“ (citizens' attitudes toward the state), which describes the readiness of individuals (at least partly) to leave their official occupations and enter the shadow economy: it is assumed that a declining tax morality tends to increase the size of the shadow economy. ${ }^{50)}$

\section{Indicators}

A change in the size of the shadow economy may be reflected in the following indicators:

(i) Development of monetary indicators. If activities in the shadow economy rise, additional monetary transactions are required.

(ii) Development of the labor market. Increasing participation of workers in the hidden sector results in a decrease in participation in the official economy. Similarly, increased activities in the hidden sector may be expected to be reflected in shorter working hours in the official economy.

(iii) Development of the production market. An increase in the shadow economy means that inputs (especially labor) move out of the official economy (at least partly), and this displacement might have a depressing effect on the official growth rate of the economy.

The latest use of the model approach has been undertaken by Giles (1999a, 1999b, 1999c) and by Giles, Tedds and Werkneh (2002), Giles and Tedds (2002), Chatterjee, Chaudhury and Schneider (2006) and Bajada and Schneider (2005). They basically estimate a comprehensive

\footnotetext{
${ }^{49)}$ Thomas (1992); Schneider (1994a, 1997, 2003, 2005); Pozo (1996); Johnson, Kaufmann and Zoido-Lobatón (1998a, 1998b); Giles (1997a, 1997b, 1999a, 1999b, 1999c); Giles and Tedds (2002), Giles, Tedds and Werkneh (2002), Del'Anno (2003) and Del'Anno and Schneider (2004).

${ }^{50)}$ When applying this approach for European countries, Frey and Weck-Hannemann (1984) had the difficulty in obtaining reliable data for the cause series, besides the ones of direct and indirect tax burden. Hence, their study was criticized by Helberger and Knepel (1988), who argue that the results were unstable with respect to changing variables in the model and over the years.
} 
(sometime dynamic) MIMIC model to get a time series index of the hidden/measured output of New Zealand, Canada, India or Australia, and then estimate a separate "cash-demand model" to obtain a benchmark for converting this index into percentage units. Unlike earlier empirical studies of the hidden economy, they paid proper attention to the non-stationary, and possible co-integration of time serious data in both models. Again this DYMIMIC model treats hidden output as a latent variable, and uses several (measurable) causal variables and indicator variables. The former include measures of the average and marginal tax rates, inflation, real income and the degree of regulation in the economy. The latter include changes in the (male) labor force participation rate and in the cash/money supply ratio. In their cashdemand equation they allow for different velocities of currency circulation in the hidden and recorded economies. Their cash-demand equation is not used as an input to determine the variation in the hidden economy over time - it is used only to obtain the long-run average value of hidden/measured output, so that the index for this ratio predicted by the DYMIMIC model can be used to calculate a level and the percentage units of the shadow economy. Overall, this latest combination of the currency demand and DYMIMIC approach clearly shows that some progress in the estimation technique of the shadow economy has been achieved and a number of critical points have been overcome.

However, also against the (DY)MIMIC method objections can be raised, too, which are

(1) instability in the estimated coefficients with respect to sample size changes,

(2) instability in the estimated coefficients with respect to alternative specifications,

(3) difficulty to obtain reliable data on cause variables other than tax variables, and

(4) the reliability of the variables grouping into "causes" and "indicators" in explaining the variability of the shadow economy.

\subsection{Summarizing the Critical Remarks}

In the table 5.4 some more general weaknesses/criticisms of the different methods to estimate the shadow economy are summarized. Tabel 5.5 clearly shows, that each methods has it's strength and weaknesses and that we are far away from having an ideal or most preferred estimation method. When undertaking the difficult and challenging task to estimate the shadow economy, all methods have weaknesses and it is important to report and to consider them and to treat the size and development of shadow economy with great care. 


\section{Some critical Points of the Different Estimation Methods}

\begin{tabular}{|l}
\hline 1. Surveys \\
\hline (1) Quite often only households or only partly firms are considered \\
(2) Non-responses and/or incorrect responses
\end{tabular}

2.Estimations of national account statisticians (quite often the discrepancy method):

(1) Combination of meso estimates/assumptions

(2) Often not published

(3) Documentation and procedures often not public

3. Monetary and/or electricity methods:

(1) Some estimates are very high

(2) Are the assumptions plausible?

(3) Breakdown by sector or industry possible?

4. DYMIMIC method

(1) only relative coefficients, no absolute values

(2) estimations quite often highly sensitive with respect to changes in the data.

\subsection{The Size and Development of the Shadow Economies of 145 Countries over $1999 / 2000$ to $2002 / 2003$}

Finally, the results of the size and development of the shadow economies of 145 countries are shown (and the countries are listed in alphabetical order) in table 5.5.

Table 6.5: The Size of the Shadow Economy of 145 Countries

\begin{tabular}{|c|c|c|c|c|}
\hline \multirow[b]{2}{*}{ No. } & \multirow[b]{2}{*}{ Country } & \multicolumn{3}{|c|}{$\begin{array}{l}\text { Shadow Economy (in \% of off. GDP) using } \\
\text { the DYMIMIC and Currency Demand Method }\end{array}$} \\
\hline & & $1999 / 00$ & $2001 / 02$ & $2002 / 03$ \\
\hline 1 & Albania & 33,4 & 34,6 & 35,3 \\
\hline 2 & Algeria & 34,1 & 35,0 & 35,6 \\
\hline 3 & Angola & 43,2 & 44,1 & 45,2 \\
\hline 4 & Argentina & 25,4 & 27,1 & 28,9 \\
\hline 5 & Armenia & 46,3 & 47,8 & 49,1 \\
\hline 6 & Australia & 14,3 & 14,1 & 13,5 \\
\hline 7 & Austria & 9,8 & 10,6 & 10,9 \\
\hline 8 & Azerbaijan & 60,6 & 61,1 & 61,3 \\
\hline 9 & Bangladesh & 35,6 & 36,5 & 37,7 \\
\hline 10 & Belarus & 48,1 & 49,3 & 50,4 \\
\hline 11 & Belgium & 22,2 & 22,0 & 21,0 \\
\hline
\end{tabular}


Table 6.5: The Size of the Shadow Economy of 145 Countries (cont.)

\begin{tabular}{|c|c|c|c|c|}
\hline \multirow[b]{2}{*}{ No. } & \multirow[b]{2}{*}{ Country } & \multicolumn{3}{|c|}{$\begin{array}{l}\text { Shadow Economy (in \% of off. GDP) using } \\
\text { the DYMIMIC and Currency Demand Method }\end{array}$} \\
\hline & & $1999 / 00$ & $2001 / 02$ & $2002 / 03$ \\
\hline 12 & Benin & 47,3 & 48,2 & 49,1 \\
\hline 13 & Bhutan & 29,4 & 30,5 & 31,7 \\
\hline 14 & Bolivia & 67,1 & 68,1 & 68,3 \\
\hline 15 & Bosnia and Herzegovina & 34,1 & 35,4 & 36,7 \\
\hline 16 & Botswana & 33,4 & 33,9 & 34,6 \\
\hline 17 & Brazil & 39,8 & 40,9 & 42,3 \\
\hline 18 & Bulgaria & 36,9 & 37,1 & 38,3 \\
\hline 19 & Burkina Faso & 41,4 & 42,6 & 43,3 \\
\hline 20 & Burundi & 36,9 & 37,6 & 38,7 \\
\hline 21 & Cambodia & 50,1 & 51,3 & 52,4 \\
\hline 22 & Cameroon & 32,8 & 33,7 & 34,9 \\
\hline 23 & Canada & 16,0 & 15,8 & 15,2 \\
\hline 24 & Central African Republic & 44,3 & 45,4 & 46,1 \\
\hline 25 & Chad & 46,2 & 47,1 & 48,0 \\
\hline 26 & Chile & 19,8 & 20,3 & 20,9 \\
\hline 27 & China & 13,1 & 14,4 & 15,6 \\
\hline 28 & Colombia & 39,1 & 41,3 & 43,4 \\
\hline 29 & Congo, Dem. Rep. & 48,0 & 48,8 & 49,7 \\
\hline 30 & Congo, Rep. & 48,2 & 49,1 & 50,1 \\
\hline 31 & Costa Rica & 26,2 & 27,0 & 27,8 \\
\hline 32 & Cote d'Ivoire & 43,2 & 44,3 & 45,2 \\
\hline 33 & Croatia & 33,4 & 34,2 & 35,4 \\
\hline 34 & Czech Republic & 19,1 & 19,6 & 20,1 \\
\hline 35 & Denmark & 18,0 & 17,9 & 17,3 \\
\hline 36 & Dominican Republic & 32,1 & 33,4 & 34,1 \\
\hline 37 & Ecuador & 34,4 & 35,1 & 36,7 \\
\hline 38 & Egypt, Arab Rep. & 35,1 & 36,0 & 36,9 \\
\hline 39 & El Salvador & 46,3 & 47,1 & 48,3 \\
\hline 40 & Estonia & 38,4 & 39,2 & 40,1 \\
\hline 41 & Ethiopia & 40,3 & 41,4 & 42,1 \\
\hline 42 & Fiji & 33,6 & 34,3 & 35,1 \\
\hline 43 & Finland & 18,1 & 18,0 & 17,4 \\
\hline 44 & France & 15,2 & 15,0 & 14,5 \\
\hline 45 & Georgia & 67,3 & 67,6 & 68,0 \\
\hline 46 & Germany & 16,0 & 16,3 & 16,8 \\
\hline 47 & Ghana & 41,9 & 42,7 & 43,6 \\
\hline 48 & Greece & 28,7 & 28,5 & 28,2 \\
\hline 49 & Guatemala & 51,5 & 51,9 & 52,4 \\
\hline 50 & Guinea & 39,6 & 40,8 & 41,3 \\
\hline 51 & Haiti & 55,4 & 57,1 & 58,6 \\
\hline 52 & Honduras & 49,6 & 50,8 & 51,6 \\
\hline 53 & Hong Kong, China & 16,6 & 17,1 & 17,2 \\
\hline 54 & Hungary & 25,1 & 25,7 & 26,2 \\
\hline 55 & India & 23,1 & 24,2 & 25,6 \\
\hline 56 & Indonesia & 19,4 & 21,8 & 22,9 \\
\hline 57 & Iran, Islamic Rep. & 18,9 & 19,4 & 19,9 \\
\hline 58 & Ireland & 15,9 & 15,7 & 15,3 \\
\hline 59 & Israel & 21,9 & 22,8 & 23,9 \\
\hline
\end{tabular}


Table 6.5: The Size of the Shadow Economy of 145 Countries (cont.)

\begin{tabular}{|c|c|c|c|c|}
\hline \multirow[b]{2}{*}{ No. } & \multirow[b]{2}{*}{ Country } & \multicolumn{3}{|c|}{$\begin{array}{l}\text { Shadow Economy (in \% of off. GDP) using } \\
\text { the DYMIMIC and Currency Demand Method }\end{array}$} \\
\hline & & 1999/00 & $2001 / 02$ & $2002 / 03$ \\
\hline 60 & Italy & 27,1 & 27,0 & 25,7 \\
\hline 61 & Jamaica & 36,4 & 37,8 & 38,9 \\
\hline 62 & Japan & 11,2 & 11,1 & 10,8 \\
\hline 63 & Jordan & 19,4 & 20,5 & 21,6 \\
\hline 64 & Kazakhstan & 43,2 & 44,1 & 45,2 \\
\hline 65 & Kenya & 34,3 & 35,1 & 36,0 \\
\hline 66 & Kiribati & 34,1 & 35,0 & 35,3 \\
\hline 67 & Korea, Rep. & 27,5 & 28,1 & 28,8 \\
\hline 68 & Kuwait & 20,1 & 20,7 & 21,6 \\
\hline 69 & Kyrgyz Republic & 39,8 & 40,3 & 41,2 \\
\hline 70 & Lao PDR & 30,6 & 31,9 & 33,4 \\
\hline 71 & Latvia & 39,9 & 40,7 & 41,3 \\
\hline 72 & Lebanon & 34,1 & 35,6 & 36,2 \\
\hline 73 & Lesotho & 31,3 & 32,4 & 33,3 \\
\hline 74 & Lithuania & 30,3 & 31,4 & 32,6 \\
\hline 75 & Macedonia, FYR & 34,1 & 35,1 & 36,3 \\
\hline 76 & Madagascar & 39,6 & 40,4 & 41,6 \\
\hline 77 & Malawi & 40,3 & 41,2 & 42,1 \\
\hline 78 & Malaysia & 31,1 & 31,6 & 32,2 \\
\hline 79 & Maldives & 30,3 & 31,4 & 32,0 \\
\hline 80 & Mali & 42,3 & 43,9 & 44,7 \\
\hline 81 & Marshall Islands & 28,1 & 29,0 & 29,6 \\
\hline 82 & Mauritania & 36,1 & 37,2 & 38,0 \\
\hline 83 & Mexico & 30,1 & 31,8 & 33,2 \\
\hline 84 & Micronesia, Fed. Sts. & 31,3 & 32,1 & 33,2 \\
\hline 85 & Moldova & 45,1 & 47,3 & 49,4 \\
\hline 86 & Mongolia & 18,4 & 19,6 & 20,4 \\
\hline 87 & Morocco & 36,4 & 37,1 & 37,9 \\
\hline 88 & Mozambique & 40,3 & 41,3 & 42,4 \\
\hline 89 & Namibia & 31,4 & 32,6 & 33,4 \\
\hline 90 & Nepal & 38,4 & 39,7 & 40,8 \\
\hline 91 & Netherlands & 13,1 & 13,0 & 12,6 \\
\hline 92 & New Zealand & 12,8 & 12,6 & 12,3 \\
\hline 93 & Nicaragua & 45,2 & 46,9 & 48,2 \\
\hline 94 & Niger & 41,9 & 42,6 & 43,8 \\
\hline 95 & Nigeria & 57,9 & 58,6 & 59,4 \\
\hline 96 & Norway & 19,1 & 19,0 & 18,4 \\
\hline 97 & Oman & 18,9 & 19,4 & 19,8 \\
\hline 98 & Pakistan & 36,8 & 37,9 & 38,7 \\
\hline 99 & Palau & 28,4 & 29,2 & 30,0 \\
\hline 100 & Panama & 64,1 & 65,1 & 65,3 \\
\hline 101 & Papua New Guinea & 36,1 & 37,3 & 38,6 \\
\hline 102 & Paraguay & 27,4 & 29,2 & 31,4 \\
\hline 103 & Peru & 59,9 & 60,3 & 60,9 \\
\hline 104 & Philippines & 43,4 & 44,5 & 45,6 \\
\hline 105 & Poland & 27,6 & 28,2 & 28,9 \\
\hline 106 & Portugal & 22,7 & 22,5 & 21,9 \\
\hline 107 & Puerto Rico & 28,4 & 29,4 & 30,7 \\
\hline
\end{tabular}


Table 6.5: The Size of the Shadow Economy of 145 Countries (cont.)

\begin{tabular}{|c|c|c|c|c|}
\hline \multirow[b]{2}{*}{ No. } & \multirow[b]{2}{*}{ Country } & \multicolumn{3}{|c|}{$\begin{array}{l}\text { Shadow Economy (in \% of off. GDP) using } \\
\text { the DYMIMIC and Currency Demand Method }\end{array}$} \\
\hline & & $1999 / 00$ & $2001 / 02$ & $2002 / 03$ \\
\hline 108 & Romania & 34,4 & 36,1 & 37,4 \\
\hline 109 & Russian Federation & 46,1 & 47,5 & 48,7 \\
\hline 110 & Rwanda & 40,3 & 41,4 & 42,2 \\
\hline 111 & Samoa & 31,4 & 32,6 & 33,5 \\
\hline 112 & Saudi Arabia & 18,4 & 19,1 & 19,7 \\
\hline 113 & Senegal & 45,1 & 46,8 & 47,5 \\
\hline 114 & Serbia and Montenegro & 36,4 & 37,3 & 39,1 \\
\hline 115 & Sierra Leone & 41,7 & 42,8 & 43,9 \\
\hline 116 & Singapore & 13,1 & 13,4 & 13,7 \\
\hline 117 & Slovak Republic & 18,9 & 19,3 & 20,2 \\
\hline 118 & Slovenia & 27,1 & 28,3 & 29,4 \\
\hline 119 & Solomon Islands & 33,4 & 34,5 & 35,3 \\
\hline 120 & South Africa & 28,4 & 29,1 & 29,5 \\
\hline 121 & Spain & 22,7 & 22,5 & 22,0 \\
\hline 122 & Sri Lanka & 44,6 & 45,9 & 47,2 \\
\hline 123 & Sweden & 19,2 & 19,1 & 18,3 \\
\hline 124 & Switzerland & 8,6 & 9,4 & 9,4 \\
\hline 125 & Syrian Arab Republic & 19,3 & 20,4 & 21,6 \\
\hline 126 & Taiwan, China & 25,4 & 26,6 & 27,7 \\
\hline 127 & Tanzania & 58,3 & 59,4 & 60,2 \\
\hline 128 & Thailand & 52,6 & 53,4 & 54,1 \\
\hline 129 & Togo & 35,1 & 39,2 & 40,4 \\
\hline 130 & Tonga & 35,1 & 36,3 & 37,4 \\
\hline 131 & Tunisia & 38,4 & 39,1 & 39,9 \\
\hline 132 & Turkey & 32,1 & 33,2 & 34,3 \\
\hline 133 & Uganda & 43,1 & 44,6 & 45,4 \\
\hline 134 & Ukraine & 52,2 & 53,6 & 54,7 \\
\hline 135 & United Arab Emirates & 26,4 & 27,1 & 27,8 \\
\hline 136 & United Kingdom & 12,7 & 12,5 & 12,2 \\
\hline 137 & United States & 8,7 & 8,7 & 8,4 \\
\hline 138 & Uruguay & 51,1 & 51,4 & 51,9 \\
\hline 139 & Uzbekistan & 34,1 & 35,7 & 37,2 \\
\hline 140 & Vanuatu & 30,9 & 31,7 & 32,5 \\
\hline 141 & Venezuela, RB & 33,6 & 35,1 & 36,7 \\
\hline 142 & Vietnam & 15,6 & 16,9 & 17,9 \\
\hline 143 & Yemen, Rep. & 27,4 & 28,4 & 29,1 \\
\hline 144 & Zambia & 48,9 & 49,7 & 50,8 \\
\hline 145 & Zimbabwe & 59,4 & 61 & 63,2 \\
\hline \multicolumn{2}{|c|}{ Unweighted Average } & 33,6 & 34,5 & 35,2 \\
\hline
\end{tabular}




\section{Appendix 2: Definition of the variables and data sources}

\subsection{Some general remarks}

(1) All calculations and estimations are based on the software package "Intercooled Stata 8.0"

(2) All growth rates or shares as described in the following section. For example a growth rate of $2 \%$ is defined as 0.02 instead of 2.0 .

(3) In for some reasons observations for important countries for 1 year are missing we used the following formula to calculate the average growth rate for these variables:

$\left(\text { variable }_{t+n} / \text { variable }_{t}\right)^{1 / n}$

Multiplying the value of the variable from year $t$ with the average growth rate gives the value for $\mathrm{t}+1$. Formally:

$\left(\right.$ Average growth rate) $\mathrm{x}\left(\right.$ variable $\left._{t}\right)=$ variable $_{t+1}$

\subsection{Definition of the data and sources}

\section{(1) GDP per capita on PPP basis}

GDP per capita is based on purchasing power parity [PPP]. PPP GDP is gross domestic product converted to international dollars using purchasing power parity rates. An international dollar has the same purchasing power over GDP as the U.S. dollar has in the United States. GDP is the sum of gross value added by all resident producers in the economy plus any product taxes and minus any subsidies not included in the value of the products. It is calculated without making deductions for depreciation of fabricated assets or for depletion and degradation of natural resources. Data are in current dollars.

Source: World Bank, International Comparison Programme database.

\section{(2) Annual GDP per capita Growth Rate}

Out of this GDP per capita values for the observed 145 countries the independent variable annual GDP per capita Growth Rate has been calculated using the formula 
Per Capita Growth $=\frac{\left(G D P p c_{t}-G D P p c_{t-1}\right)}{G D P p c_{t-1}}$

Source: World Bank, International Comparison Programme database; own calculation by authors.

\section{(3) Shadow Economy}

The variable Shadow Economy is defined as the informal sector [shadow economy] in percent of official GDP. The estimations for the size of the shadow economy are undertaken using the DYMIMIC and the currency demand approaches; using the values calculated in section 3. This variable is available for three points in time namely the years 1999/00, 2001/02 and $2002 / 03$.

Source: Own calculation by the author.

\section{(4) Dummy Industrialized Countries}

The variable Dummy Industrialized Countries is a binary variable and takes the value 0 if a country is a developing country and 1 if the country is an industrialized country. "Developing Country" corresponds to high income classification of World Bank Indicators 2002 with per capita income of USD 9,265 or less. The same applies to "Industrialized Countries" which are defined as countries with per capita GDP of USD 9,266 or more.

Source: Own calculation by authors.

\section{(5) Dummy Transition countries}

The variable Dummy Transition Countries is a binary variable and takes the value 1 if a country is a transition country from a centrally planned economy to a market economy and 0 if the country is not. This variable is used for the classification of the countries.

Source: Own Calculation by authors.

\section{(6) Dummy OECD countries}

The variable Dummy OECD countries is a binary variable and takes the value 1 if a country is member of the OECD and 0 if the country is not.

Source: Own Calculation by authors.

\section{(7) Share of Direct Taxation (in \% of GDP)}

Source: OECD, Paris 2003, Taxing Wages and World Bank (Washington D.C.), 2003, Governance Indicators. 
(8) Share of Indirect Taxation and Custom Duties in \% of GDP

Source: See Share of Direct Taxation.

\section{(9) Burden of State Regulation}

Burden of State regulation, index of regulation, where a score is of 1 signifies and economic environment most conductive to economic freedom, where a less score of 5 signifies least economic freedom. Source: Heritage Foundation 2005, Index of Economic Freedom, Washington, D.C.

(10) Employment Quota (in \% of population between 18 and 64)

Source: OECD, Paris, various years, Employment Outlook.

(11) Unemployment Quota (\% of unemployed in the working force)

Source: OECD various years, Employment Outlook.

\section{(12) Change of Currency per Capita, Annual Rate of Currency per Capita}

Source: World Bank National Accounts Data and OECD National Accounts Data Files, Washington and Paris, various years.

\section{(13) Tax Morale (Index)}

Source: European Values Study, EUROPEAN VALUES STUDY, 1999/2000 [Computer file] 2003/Release 1, The Netherlands, Germany: Tilburg University, Zentralarchiv für Empirische Sozialforschung, Cologne (ZA), Netherlands Institute for Scientific Information Services (NIWI), Amsterdam [producer], 2003. Germany: Zentralarchiv für Empirische Sozialforschung, Cologne [distributor], 2003. Inglehart, Ronald et.al. World Values Surveys and European Values Surveys, 1981-1984, 1990-1993 and 1995-1997 [Computer file]. ICPSR version. Ann Arbor, MI: Institute for Social Research [producer], 2000. Ann Arbor, MI: Interuniversity Consortium for Political and Social Research [distributor], 2000.

\section{(14) Quality of Institutions}

index $=0$ lowest quality, $=100$ highest quality, Source World Bank, years 1999 to 2003 


\section{(15) Social Security Burden}

Definition: social security payments (employers and employees) in \% of GDP, Source OECD, 2003, 2004

Quality of state institutions, World Bank rule of law index, ranges from -3 to +3 , with higher scores showing better environments, i.e. the higher the score the better is the rule of law in that respective country. Source: Kaufmann, D.; Kraay, A. and M. Mastruzzi, 2003, Governments Matters III: Governments Indicators for 1996/2002, World Bank Policy Research Working Papers 3106, World Bank, Washington D.C.

\section{Appendix 3: Descriptive Statistics of the variables}

\begin{tabular}{|l|c|c|c|c|}
\hline Variable & Mean & Minimum & Maximum & $\begin{array}{c}\text { Standard } \\
\text { Deviation }\end{array}$ \\
\hline Shadow Economy & 31.78 & 6.90 & 68.20 & 12.72 \\
\hline Income tax rate (Fraser) & 4.95 & 0.00 & 10.00 & 3.01 \\
\hline Custom duties (\% of GDP) & 6.44 & 0.00 & 10.00 & 2.34 \\
\hline Direct Taxes (\% of GDP) & 20.20 & 0.37 & 47.28 & 9.69 \\
\hline Indirect Taxes (\% of GDP) & 24.63 & 0.04 & 58.76 & 10.48 \\
\hline Regulation (Heritage) & 3.37 & 1.00 & 5.00 & 0.93 \\
\hline Rule of law (World Bank) & 0.00 & -2.04 & 2.36 & 0.98 \\
\hline Government effectiveness (World Bank) & -0.02 & -2.28 & 2.59 & 0.95 \\
\hline Social security burden (\% of GDP) & 18.3 & 0.00 & 26.3 & 6.42 \\
\hline Tax morale & 4.51 & 1.78 & 8.46 & 2.32 \\
\hline Unemployment quota & 9.46 & 3.41 & 24.36 & 3.43 \\
\hline GDP per capita in USD & 14532.01 & 543.74 & 37541.23 & 10552.23 \\
\hline Annual rate of GDP (\%) & 6.62 & -5.58 & 12.64 & 2.34 \\
\hline Change of local currency per capita & 7.47 & 0.21 & 14.64 & 3.24 \\
\hline Employment quota & 40.23 & 34.12 & 66.41 & 16.43 \\
\hline
\end{tabular}




\section{References}

Ahumada, Hildegard, Alvaredo, Facundo, Canavese Alfredo. and Paula. Canavese (2004): The demand for currency approach and the size of the shadow economy: A critical assessment, Discussion Paper, Delta Ecole. Normale Superieure, Paris.

Adam, Markus, C. and Victor Ginsburgh, (1985), The effects of irregular markets on macroeconomic policy: Some estimates for Belgium, European Economic Review, 29/1, pp. 15-33.

Aigner, Dennis; Schneider, Friedrich and Damayanti Ghosh (1988): Me and my shadow: estimating the size of the US hidden economy from time series data, in W. A. Barnett; E. R. Berndt and H. White (eds.): Dynamic econometric modeling, Cambridge (Mass.): Cambridge University Press, pp. 224-243.

Alexeev, Michael and Pyle, William (2003): A note on measuring the unofficial economy in the former Soviet Republics, Economics of Transition, 11/1, p.1-23.

Alderslade, Jamie, John Talmage and Yusef Freeman (2006): Measuring the Informal Economy: One Neighborhood at a Time, Discussion Paper, The Brooking Institution Metropolitan Policy Program, Washington D.C., September 2006.

Alm, James, Martinez-Vazquez, Jorge and Friedrich Schneider (2004), 'Sizing the problem of the hard-to-tax', Working Paper, Georgia State University: USA.

Andreoni, James; Erard, Brian, and Jonathan Feinstein (1998): Tax compliance. Journal of Economic Literature, 36, pp. 818-860.

Asea, Patrick K. (1996): The informal sector: baby or bath water? Carnegie-Rochester Conference Series on Public Policy 45., pp. 163-171.

Bajada Christopher (2002): Australia's Cash Economy: A Troubling Issue for Policy Makers. Aldershort (Great Britain), Ashgate Publishing Company.

Bajada, Christopher and Friedrich Schneider (2003): The size and development of the shadow economies in the Asia-Pacific, Discussion Paper, Department of Economics, University of Linz, Austria, published in the Asian Pacific Economic Journal, 2005.

Bajada, Christopher and Friedrich Schneider (2005): Size, Causes and Consequences of the Underground Economy: An International Perspective, Aldershot (GB): Ashgate Publishing Company.

Barro, Robert. J. and Sala-i-Martin, Xavier. (1995), 'Economic Growth', McGraw-Hill: USA.

Belev, Boyan (2003): The informal economy in the EU Accession Countries: Size, scope, trends and challenges to the process of EU enlargement, Center for Study of Democracy, Sofia.

Bhattacharyya, D.K. (1999): On the economic rationale of estimating the hidden economy, The Economic Journal 109/456, pp. 348-359.

Blades, Derek (1982): “The hidden economy and the national accounts", OECD (Occasional Studies), Paris, pp. 28-44.

Boeschoten, Werner C. and Marcel M.G. Fase (1984): The Volume of Payments and the Informal Economy in the Netherlands 1965-1982, M. Nijhoff, Dordrecht.

Brehm, J.W. (1966): A Theory of Psychological Reactance. New York (Academic Press).

Brehm, J.W. (1972): Responses to Loss of Freedom. A Theory of Psychological Reactance. Morristown (General Learning Press).

Breusch, Trevor (2005a): "The Canadian Underground Economy: An Examination of Giles and Tedds", Canadian Tax Journal, 53/2, pp.367-391.

Breusch, Trevor (2005b): "Estimating the Underground Economy, Using MIMIC Models", Working Paper, National University of Australia, Canberra, Australia.

Brueck, Tilman, John B. Haisten-DeNew and Klaus F. Zimmermann (2006): Creating low-skilled Jobs by Subsidizing Market Contracted Household Work, Applied Economics 38/4, pp.899-911.

Cagan, Phillip (1958): “The demand for currency relative to the total money supply," Journal of Political Economy, 66:3, pp. 302-328.

Chatterjee, S.; Chaudhury K. and F. Schneider (2006): The size and development of the Indian shadow economy and a comparison with other 18 Asian countries: An empirical investigation, forthcoming in the Journal of Development Economics, April 2006.

Chen, Martha (2004): Rethinking the informal economy: Linkages with the formal economy and the formal regulatory environment, paper presented at the EGDI-WIDR Conference 'unleashing human potential: linking the informal and formal sectors, Helsinki, Finland, 2004. 
Choi, J. and M. Thum, 2004, Corruption and the shadow economy, International Economic Review 12/4, pp.308-342.

Clotefelter, Charles T. (1983): Tax evasion and tax rates: An analysis of individual return, Review of Economic Statistics, 65/3, pp. 363-373.

Contini, Bruno (1981): Labor market segmentation and the development of the parallel economy - the Italian experience, Oxford Economic Papers, 33/4, pp. 401-12.

Dallago, Bruno (1990): The irregular economy: The "underground economy" and the "black labour market", Dartmouth (U.K.), Publishing Company.

Del'Anno, Roberto (2003): Estimating the shadow economy in Italy: A structural equation approach, Discussion Paper, Department of Economics and Statistics, University of Salerno.

Del'Anno, Roberto and Friedrich Schneider (2004): The shadow economy of Italy and other OECD countries: What do we know?, Linz: University of Linz, Department of Economics, Discussion Paper, published in Journal of Public Finance and Public Choice, 2005.

Del'Anno, Roberto and Friedrich Schneider (2005): Estimating the Underground Economy by Using MIMIC Models: A Response to T.Breuschs Critic, Discussion Paper, Department of Economics, University of Linz, Linz.

Del Boca, Daniela. (1981): Parallel economy and allocation of time, Micros (Quarterly Journal of Microeconomics), 4/2, pp. 13-18.

Del Boca, Daniela and Francesco Forte (1982): Recent empirical surveys and theoretical interpretations of the parallel economy in Italy; Tanzi, Vito (1982) (ed.): The underground economy in the United States and abroad, Lexington (Mass.), Lexington, pp. 160-178.

Dreher, Axel; Christos Kotsogiannis and Steve McCorriston, 2005a, How do Institutions Affect Corruption and the Shadow Economy? University of Konstanz and University of Exeter, mimeo.

Dreher, Axel; Christos Kotsogiannis and Steve McCorriston, 2005b, Corruption around the World: Evidence from a Structural Model, University of Konstanz and University of Exeter, mimeo.

Dreher, Axel and Lars-H.R. Siemers, 2005, The Intriguing Nexus Between Corruption and Capital Account Restrictions, KOF Working Paper 113, Swiss Federal Institute of Technology (ETH Zurich).

Dreher, Axel and Friedrich Schneider (2006): Corruption and Shadow Economy: An Empirical Analysis, Discussion Paper, Department of Economies, University of Linz, 2006.

Feige, Edgar L. (1986): A re-examination of the "Underground Economy" in the United States. IMF Staff Papers, 33/ 4, pp. 768-781.

Feige, Edgar L. (1989) (ed.): The Underground Economies. Tax Evasion and Information Distortion. Cambridge, New York, Melbourne, Cambridge University Press.

Feige, Edgar L. (1994): The underground economy and the currency enigma, Supplement to Public Finance/ Finances Publiques, 49, pp. 119-136.

Feige, Edgar L. (1996): Overseas holdings of U.S. currency and the underground economy, in: Pozo, Susan (ed.): Exploring the Underground Economy. Kalamazoo, Michigan, pp. 5-62.

Flaming, Daniel; Breut Hayolamak and Pascale Jossart (2005), Hopeful Workers, Marginal Jobs: LA's Off-TheBooks Labor Force, Economic Roundtable, Los Angeles, CA, 2005.

Fleming, M.H.; Roman, J. and G. Farrel (2000): The shadow economy, Journal of International Affairs, Spring 2000, No. 53/2, pp.64-89.

Franz, A. (1983): Wie groß ist die "schwarze" Wirtschaft?, Mitteilungsblatt der Österreichischen Statistischen Gesellschaft, 49/1, pp. 1-6.

Feld, Lars, and Bruno S. Frey (2002), The Tax of Authority and the Taxpayer: And Exploratory Analysis, Unpublished Manuscript, University of Zürich, Switzerland

Feld, Lars, and Bruno S. Frey (2002a), Trust preeds trust: How Taxpayers are treated, Economics of Governments, 3/1, pp 87-89.

Feld, Lars and Claus Larsen (2005): Black Activities in Germany in 2001 and 2004: A Comparison Based on Survey Data, The Rockwool Foundation Research Unit, Copenhagen (DK), 2005.

Frey, Bruno S, (1997), Not just for the Money: An Economic Theory of Personal Motivation, Cheltonham (UK): Edward Elgar

Feld, Lars, and Bruno S. Frey, (2005), “Tax Complains as the Result of a Psychological Tax Contract: The Role of Incentives and Responsioe Regulation”, Discussion Paper, University of Marburg, Germany

Frey, Bruno S. and Hannelore Weck (1983a): "Bureaucracy and the Shadow Economy: A Macro-Approach", in Horst Hanusch (ed.): Anatomy of Government Deficiencies. Berlin: Springer, pp. 89-109. 
Frey, Bruno S. and Hannelore Weck (1983b): "Estimating the Shadow Economy: A 'Naive' Approach," Oxford Economic Papers, 35, pp. 23-44.

Frey, Bruno S. and Hannelore Weck-Hannemann (1984): The hidden economy as an "unobserved" variable, European Economic Review, 26/1, pp. 33-53.

Frey, Bruno S. and Werner Pommerehne (1984): The hidden economy: State and prospect for measurement, Review of Income and Wealth, 30/1, pp. 1-23.

Frey, Bruno S., Weck Hannelore and Werner W. Pommerehne (1982): Has the shadow economy grown in Germany? An exploratory study, Weltwirtschaftliches Archiv, 118/4, pp. 499-524.

Friedman, E., Johnson, S., Kaufmann, D. and Zoido-Labton, P. (2000): Dodging the grabbing hand: The determinants of unofficial activity in 69 countries, Journal of Public Economics, 76/4, pp.459-493.

Garcia, Gillian (1978): “The currency ratio and the subterranean economy,” Financial Analysts Journal, 69:1, pp. 64-66.

Gerxhani, Klarita (2003): The informal sector in developed and less-developed countries: A literature survey, Public Choice, 114/3-4, pp.295-318.

Giles, David, E.A. (1997a): Causality between the measured and underground economies in New Zealand, Applied Economic Letters 4, pp.63-67.

Giles, David, E.A. (1997b): Testing the asymmetry in the measured and underground business cycles in New Zealand, Economic Record 71/1, pp.225-232.

Giles, David, E.A. (1999a): Measuring the hidden economy: Implications for econometric modelling, The Economic Journal, 109/456, pp.370-380.

Giles, David, E.A. (1999b): Modelling the hidden economy in the tax-gap in New Zealand, Empirical Economics 24/4, pp.621-640.

Giles, David, E.A. (1999c): The rise and fall of the New Zealand underground economy: are the reasons symmetric?, Applied Economic Letters 6, pp. 185-189.

Giles, David, E.A. and Lindsay M. Tedds (2002): Taxes and the Canadian Underground Economy, Canadian Tax Paper No. 106, Canadian Tax Foundation, Toronto/Ontario.

Giles, David, E.A., Tedds, Lindsay, M. and Werkneh, Gugsa (2002): The Canadian underground and measured economies, Applied Economics, 34/4, pp.2347-2352.

Gutmann, Pierre M. (1977): “The subterranean economy,” Financial Analysts Journal, 34:1, pp. $24-27$.

Halla, Martin and Friedrich Schneider (2005), "Taxes and Benefits: Two Distuct Options to Cheal on the Stole?”, Discussion Paper, Institute of Economics, University of Linz, Linz (Austria)

Helberger, Claus and Hans Knepel (1988): "How big is the shadow economy? A re-analysis of the unobservedvariable approach of B. S. Frey and H. Weck-Hannemann”, European Economic Journal, 32, pp. 965-76.

Hill, Roderick and Muhammed Kabir (1996): Tax rates, the tax mix, and the growth of the underground economy in Canada: What can we infer? Canadian Tax Journal/ Revue Fiscale Canadienne, 44/ 6, pp. $1552-1583$.

Hindriks, J.; A. Muthoo and M. Keen, 1999, Corruption, extortion and evasion, Journal of Public Economics 74: 395-430.

IRS (1979): Estimates of Income Unreported on Individual Tax Reforms, Washington D.C.: Internal revenue service, U.S. Department of the Treasury.

IRS (1983): Income Tax Compliance Research: Estimates for 1973-81, Washington D.C.: Internal revenue service, U.S. Department of the Treasury.

Isachsen, Arne J. and Steinar Strom (1985): The size and growth of the hidden economy in Norway, Review of Income and Wealth, 31/1, pp. 21-38.

Isachsen, Arne J.; Klovland, Jan and Steinar Strom (1982): The hidden economy in Norway, in: Tanzi Vito (ed.): The underground economy in the United States and Abroad, Heath, Lexington, pp. 209-231.

Janisch Urban and Dieter Brümmerhoff, (2005) Möglichkeiten und Grenzen der Schätzung der Schattenwirtschaft: Eine kritische Auseinandersetzung mit den Schätzergebnissen der Bargeldmethode nach Schneider, Diskussionspapier, Universität Rostock.

Johnson, Simon; Kaufmann, Daniel; and Andrei Shleifer (1997): The unofficial economy in transition, Brookings Papers on Economic Activity, Fall, Washington D.C.

Johnson, Simon; Kaufmann, Daniel and Pablo Zoido-Lobatón (1998a): Regulatory discretion and the unofficial economy. The American Economic Review, 88/ 2, pp. 387-392.

Johnson, Simon; Kaufmann, Daniel and Pablo Zoido-Lobatón (1998b): Corruption, public finances and the unofficial economy. Washington, D.C.: The World Bank, discussion paper. 
Karmann, Alexander (1986), Monetäre Ansätze zur Erfassung der Schattenwirtschaft: Ein Vergleich verschiedener Messansätze, Kredit und Kapitel 19/3, pp.233-247.

Karmann, Alexander (1990), Schattenwirtschaft und ihre Ursachen: Eine empirische Analyse zur Schwarzwirtschaft und Selbstversorgung in der Bundesrepublik Deutschland, Zeitschrift für Wirtschaftsund Sozialwissenschaften (ZWS) 110/3, 1990, pp.185-206.

Kaufmann, Daniel and Kaliberda, Aleksander (1996), Integrating the unofficial economy into the dynamics of post socialist economies: A framework of analyses and evidence, in: B. Kaminski (ed.), Economic Transition in Russia and the New States of Eurasia, London: M.E. Sharpe, pp.81-120.

Kazemier, Brugt, (2005a), The Undergroud Economy: A Survey of Methods and Estimates Discussion Paper, Statistics Netherlands, Voorburg, Netherlands

Kazemier, Brugt, (2005b), Monitorying the Underground Labour Market: What Surveys can do, Discussion Paper, Statistics Netherlands, Voorburg, Netherlands

Kirchgaessner, Gebhard (1983): Size and development of the West German shadow economy, 1955-1980, Zeitschrift für die gesamte Staatswissenschaft, 139/2, pp. 197-214.

Kirchgaessner, Gebhard (1984): Verfahren zur Erfassung des in der Schattenwirtschaft erarbeiteten Sozialprodukts, Allgemeines Statistisches Archiv, 68/4, pp. 378-405.

Kirchler, E.; Maciejovsky, B. and F. Schneider (2002): Everyday representations of tax avoidance, tax evasion and tax flight: Do legal differences matter?, Economic Psychology, 8/3, pp.1-19.

Klovland, Jan (1984): "Tax evasion and the demand for currency in Norway and Sweden: Is there a hidden relationship?" Scandinavian Journal of Economics, 86:4, pp. 423-39.

Lackó Mária (1996): Hidden economy in East-European countries in international comparison, Laxenburg: International Institute for Applied Systems Analysis (IIASA), working paper.

Lackó Mária (1998): The hidden economies of Visegrad countries in international comparison: A household electricity approach, In: Halpern, L. and Wyplosz, Ch. (eds.), Hungary: Towards a market economy, Cambridge (Mass.): Cambridge University Press, p.128-152.

Lackó Mária (1999): Hidden economy an unknown quantitiy? Comparative analyses of hidden economies in transition countries in 1989-95, Working paper 9905, Department of Economics, University of Linz, Austria.

Lackó Mária (2000), Hidden Economy - An unknown quantity: Comparative analysis of hidden economics in Transition countries 1989-95, Economics of Transition 8/1, pp.117-149.

Langfeldt, Enno (1984): The unobserved economy in the Federal Republic of Germany, in: Feige, Edgar L. (ed.): The unobserved economy, Cambridge University Press., pp. 236-260.

Lippert, Owen and Michael Walker (eds.) (1997): The Underground Economy: Global Evidences of its Size and Impact, Vancouver, B.C.: The Frazer Institute.

Lizzeri, C. (1979): Mezzogiorno in controluce. Enel, Naples.

Loayza, N. V. (1996): The economics of the informal sector: a simple model and some empirical evidence from Latin America. Carnegie-Rochester Conference Series on Public Policy 45, pp. 129-162.

MacAfee, Kerrick (1980): A Glimpse of the hidden economy in the national accounts, Economic Trends, 136, pp. 81-87.

Marcelli, Enrico A. (2004): Unauthorized Mexican Immigration, the Labour and other Lower-Wage Informal Employment in California, Regional Studies 38/1, pp.1-13.

Marcelli, Enrico A., Manuel Pastor jr. and Pascale M. Joassart (1999): Estimating the Effects of Informal Economic Activity: Evidence from Los Angeles County, Journal of Economic Issues 33/3, pp.579-607.

Mauleon, Ignacio (1998): Quantitative estimation of the Spanish underground economy, Discussion paper, Department of Economics and History, University of Salamanka, Salamanka, Spain.

Méon, Pierre-Guillaume and Khalid Sekkat, 2004, Does the Quality of Institutions Limit the MENA's Integration in the World Economy? The World Economy 27, 9: 1475-1498.

Mogensen, Gunnar V.; Kvist, Hans K.; Körmendi, Eszter and Soren Pedersen (1995): The shadow economy in Denmark 1994: Measurement and results, Study no. 3, Copenhagen: The Rockwool Foundation Research Unit.

Morris, B. (1993), Editorial Statement. International Economic Insides, IV, International Statistical Yearbook, Budapest.

Mummert, Annette and Friedrich Schneider (2001): The German shadow economy: Parted in a united Germany?, Finanzarchiv, 58/3, pp.260-285. 
Neck, Reinhard, Hofreither, Markus and Friedrich Schneider (1989): The consequences of progressive income taxation for the shadow economy: Some theoretical considerations, in Boes, Dieter and Felderer, Bernhard (eds.), The political economy of progressive taxation, Heidelberg: Springer publishing company, pp. 149176.

O'Higgins, Michael (1989): Assessing the underground economy in the United Kingdom, in: Feige, E.L. (ed.): The underground economies: tax evasion and information distortion, Cambridge: Cambridge University Press, pp. 175-195.

O’Neill, David M. (1983): Growth of the underground economy 1950-81: Some evidence from the current population survey, Study for the Joint Economic Committee, U.S. Congress, Joint Committee Print 98-122, U.S. Gov. Printing Office, Washington.

Park, T. (1979): Reconciliation between personal income and taxable income, pp. 1947-77, mimeo, Washington D.C.: Bureau of Economic Analysis.

Pelzmann, Linde (1988): Wirtschaftspsychologie. Arbeitslosenforschung, Schattenwirtschaft, Steuerpsychologie. Wien, New York (Springer).

Pedersen, Soren (2003): The Shadow Economy in Germany, Great Britain and Scandinavia: A Measurement Based on Questionnaire Service, Study No. 10, The Rockwoll Foundation Research Unit, Copenhagen.

Petersen, H.-G.(1982): Size of the public sector, economic growth and the informal economy: Development trends in the Federal Republic of Germany, Review of Income and Wealth, 28/2, pp. 191-215.

Pissarides, C. and Weber, G. (1988): An expenditure - based estimate of Britain's black economy, CLE working paper no. 104, London.

Portes, Alejandro (1996): The informal economy, in: Pozo, Susan (ed.): Exploring the underground economy. Kalamazoo, Michigan, pp. 147-165.

Pozo, Susan (ed.) (1996): Exploring the Underground Economy: Studies of Illegal and Unreported Activity, Michigan: W.E. Upjohn, Institute for Employment Research.

Quirk, Peter, J., (1996), Macroeconomic implications of money laundering, IMF working paper WP/96/66, Washington, D.C.

Rogoff, Kenneth, (1998), Blessing or Curse? Foreign and underground demand for euro notes, Economic policy: The European Forum 26, pp. 261-304.

Schneider, Friedrich (1986): Estimating the size of the Danish shadow economy using the currency demand approach: An attempt, The Scandinavian Journal of Economics, 88/4, pp. 643-668.

Schneider, Friedrich (1994a): Measuring the size and development of the shadow economy. Can the causes be found and the obstacles be overcome? in: Brandstaetter, Hermann, and Güth, Werner (eds.): Essays on Economic Psychology, Berlin, Heidelberg, Springer Publishing Company, pp. 193-212.

Schneider, Friedrich (1994b): Can the shadow economy be reduced through major tax reforms? An empirical investigation for Austria, Supplement to Public Finance/ Finances Publiques, 49, pp. 137-152.

Schneider, Friedrich (1997): The shadow economies of Western Europe, Journal of the Institute of Economic Affairs, 17/3, pp. 42-48.

Schneider, Friedrich (1998a): Further empirical results of the size of the shadow economy of 17 OECD-countries over time, Paper to be presented at the 54. Congress of the IIPF Cordowa, Argentina and discussion paper, Department of Economics, University of Linz, Linz, Austria.

Schneider, Friedrich (1998b): Stellt das Anwachsen der Schwarzarbeit eine wirtschaftspolitische Herausforderung dar? Einige Gedanken aus volkswirtschaftlicher Sicht. Linz, Mitteilungen des Instituts für angewandte Wirtschaftsforschung (IAW), I/98, S. 4-13.

Schneider, Friedrich (2000): The increase of the size of the shadow economy of 18 OECD-Countries: Some preliminary explanations, Paper presented at the Annual Public Choice Meeting, March 10-12, 2000, Charleston, S.C.

Schneider, Friedrich (2003): The shadow economy, in: Charles K. Rowley and Friedrich Schneider (eds.), Encyclopedia of Public Choice, Kluwer Academic Publishers, Dordrecht.

Schneider, Friedrich, 2004, Arbeit imi Schatten: „Wo Deutschlands Wirtschaft wirklich wächst.“, Wiesbaden, babler Verlag

Schneider, Friedrich (2005): Shadow Economies around the World: What do we really know?, forthcoming European Journal of Political Economy, 2005.

Schneider, Friedrich, Markus F. Hofreither and Reinhard Neck, (1989), The consequences of a changing shadow economy for the official economy: Some empirical results for Austria, in Boes, Dieter and Bernhard Felderer (eds.), The political economy of progressive taxation, Heidelberg: Springer publishing company, pp. 181-211. 
Schneider, Friedrich and Dominik Enste (2000): Shadow economies: Size, causes, and consequences, The Journal of Economic Literature, 38/1, pp. 77-114.

Schneider, F., Enste D. (2002). The Shadow Economy: Theoretical Approaches, Empirical Studies, and Political Implications, Cambridge (UK): Cambridge University Press.

Simon, C.B. and A.G. Witte (1982): Beating the system: The underground economy, Boston, (Mas.): Urban House.

Smith, J.D (1985): Market motives in the informal economy, in: Gaertner, W. and Wenig, A. (eds.): The economics of the shadow economy, Heidelberg: Springer Publishing Company, pp. 161-177.

Smith, Philip (1994): Assessing the size of the underground economy: The statistics Canada perspectives, Canadian Economic Observer, Catalogue No.: 11-010, 3.16-33, at 3.18.Spiro, Peter S. (1993): "Evidence of a Post-GST Increase in the Underground Economy;" Canadian Tax Journal/ Revue Fiscale Canadienne, , 41:2, pp. 247-258.

Tanzi, Vito (1980): “The underground economy in the United States: Estimates and implications," Banca Nazionale del Lavoro, 135:4, pp. 427-453.

Tanzi, Vito (1982) (ed.): The Underground Economy in the United States and Abroad, Lexington (Mass.), Lexington.

Tanzi, Vito (1982): A second (and more skeptical) look at the underground economy in the United States; in: Tanzi, Vito (1982) (ed.): The underground economy in the United States and abroad, Lexington (Mass.), Lexington, pp. 38-56.

Tanzi, Vito (1983): “The underground economy in the United States: Annual estimates, 1930-1980,“ IMF-Staff Papers, 30:2, pp. 283-305.

Tanzi, Vito (1986): The underground economy in the United States, Reply to comments by Feige, Thomas, and Zilberfarb. IMF - Staff Papers, 33/ 4, pp. 799-811.

Tanzi, Vito (1999): Uses and abuses of estimates of the underground economy, The Economic Journal 109/456, pp.338-340

Thomas, Jim J. (1986): The underground economy in the United States: A comment on Tanzi, IMF-Staff Papers, Vol. 33, No. 4, pp. 782-789.

Thomas, Jim J. (1992): Informal Economic Activity, LSE, Handbooks in Economics, London: Harvester Wheatsheaf.

Thomas, Jim J. (1999): Quantifying the black economy: 'Measurement without Theory' Yet Again?, The Economic Journal 109/456, pp. 381-389.

Torgler, Benno, (2002), "Speaking to Theorists and Searching for Facts: Tax Moral and Tax Compliance in Experiments", Journal of Economic Surveys, 16/5, p.657-683.

Torgler, Benno and Friedrich Schneider, (2005), “Attitudes Towards Paying Taxes in Austria: An Empirical Analysis", Empirica, forthcoming.

Weck, Hannelore (1983): Schattenwirtschaft: Eine Möglichkeit zur Einschränkung der öffentlichen Verwaltung? Eine ökonomische Analyze, Bern-Frankfurt.

Williams, Colin C. (2004a): Cash-In-Hand Work: The Underground Sector and the Hidden Economy of Favours, Haunddemills/Hampshire (GB), Palgrave McMillan Publishing Company, 2004.

Williams, Colin C. (2004b): Geographical Variations in the Nature of Undecleared Work, Geographisca Analer 86/B/3, pp.187-200.

Williams, Colin C. (2005a): Forstering Community Engagement and Tackling Undeclared Work: The Case for an Evidence - Based “joint-up” Public Policy Approach, Regional Studies 39/8, pp.1145-1155.

Williams, Colin C. (2005b): Small Business and the Informal Economy: Making the Transition to the Informal Economy - The Evidence Base, Small Business Service, London.

Williams, Colin C. (2006): What is to be done about Undecleared Work? Evaluating the Policy Options, Policy and Politics 34/1, pp.91-113.

Williams, Colin C. and Jan Windebank (1995): "Black market work in the European Community: Peripheral work for peripheral localities?”, International Journal of Urban and Regional Research, 19/1, pp. 23-39.

Williams, Colin C. and Jan Windebank (1998): Informal Employment in the Advanced Economies: Implication for Work and Welfare, Routledge, London.

Williams, Colin C. and Jan Windebank (2001a): Beyond Profit Motivated Exchange: Some Lessons from the Study of Paid Informal Work, European Urban and Regional Studies 8/1, pp.49-61.

Williams, Colin C. and Jan Windebank (2001b): Reconceptualizing Paid Informal Exchance: Some Lessons from English Cities, Environment and Planning A 33/1, pp.121-140. 
Witte, A.D. (1987): The nature and extend of unreported activity: A survey concentrating on a recent USresearch, in: Alessandrini, S. and Dallago, B. (eds.): The Unofficial Economy: Consequences and perspectives in different economic systems, Gower: Aldershot.

Zilberfarb, Ben-Zion (1986): Estimates of the underground economy in the United States, 1930-80. IMF-Staff Papers, 33/ 4, pp. 790-798. 


\section{ARBEITSPAPIERE 1991-2006 \\ des Instituts für Volkswirtschaftslehre, Johannes Kepler Universität Linz}

9101 WEISS, Christoph: Price inertia and market structure under incomplete information. Jänner 1991. in: Applied Economics, 1992.

9102 BARTEL, Rainer: Grundlagen der Wirtschaftspolitik und ihre Problematik. Ein einführender Leitfaden zur Theorie der Wirtschaftspolitik. Jänner 1991; Kurzfassung erschienen unter: Wirtschaftspolitik in der Marktwirtschaft, in: Wirtschaft und Gesellschaft, 17. 1991,2, S. 229-249

9103 FALKINGER, Josef: External effects of information. Jänner 1991

9104 SCHNEIDER, Friedrich; Mechanik und Ökonomie: Keplers Traum und die Zukunft. Jänner 1991, in: R. Sandgruber und F. Schneider (Hrsg.), "Interdisziplinarität Heute", Linz, Trauner, 1991

9105 ZWEIMÜLLER, Josef, WINTER-EBMER, Rudolf: Manpower training programs and employment stability, in: Economica, 63. 1995, S. 128-130

9106 ZWEIMÜLLER, Josef: Partial retirement and the earnings test. Februar 1991, in: Zeitschrift für Nationalökonomie / Journal of Economics, 57. 1993,3, S. 295-303

9107 FALKINGER, Josef: The impacts of policy on quality and price in a vertically integrated sector. März 1991. Revidierte Fassung: On the effects of price or quality regulations in a monopoly market, in: Jahrbuch für Sozialwissenschaft.

9108 PFAFFERMAYR, Michael, WEISS, Christoph R., ZWEIMÜLLER, Josef: Farm income, market wages, and off-farm labour supply, in: Empirica, 18, 2, 1991, S. 221-235

9109 BARTEL, Rainer, van RIETSCHOTEN, Kees: A perspective of modern public auditing. Pleading for more science and less pressure-group policy in public sector policies. Juni 1991, dt. Fassung: Eine Vision von moderner öffentlicher Finanzkontrolle, in: Das öffentliche Haushaltswesen in Österreich, 32. 1991,3-4, S. 151-187

9110 SCHNEIDER, Friedrich and LENZELBAUER, Werner: An inverse relationship between efficiency and profitability according to the size of Upper--Austrian firms? Some further tentative results, in: Small Business Economics, 5. 1993,1, S. 122

9111 SCHNEIDER, Friedrich: Wirtschaftspolitische Maßnahmen zur Steigerung der Effizienz der österreichischen Gemeinwirtschaft: Ein Plädoyer für eine aktivere Industrie- und Wettbewerbspolitik. Juli 1991, in: Öffentliche Wirtschaft und Gemeinwirtschaft in Österreich, Wien, Manz, 1992, S. 90-114

9112 WINTER-EBMER, Rudolf, ZWEIMÜLLER, Josef: Unequal promotion on job ladders, in: Journal of Labor Economics, 15. 1997,1,1, S. 70-71

9113 BRUNNER, Johann K.: Bargaining with reasonable aspirations. Oktober 1991, in: Theory and Decision, 37, 1994, S 311321.

9114 ZWEIMÜLLER, Josef, WINTER-EBMER, Rudolf: Gender wage differentials and private and public sector jobs. Oktober 1991, in: Journal of Population Economics, 7. 1994, S. 271285

9115 BRUNNER, Johann K., WICKSTRÖM, Bengt-Arne: Politically stable pay-as-you-go pension systems: Why the socialinsurance budget is too small in a democracy. November 1991, in: Zeitschrift für Nationalökonomie = Journal of Economics, 7. 1993, S. 177-190.

9116 WINTER-EBMER; Rudolf, ZWEIMÜLLER, Josef: Occupational segregation and career advancement. Dezember 1991, in: Economics Letters, 39. 1992, S. 229-234

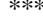

9201 SCHNEIDER, Friedrich: Ecological objectives in a market economy: Three simple questions, but no simple answers? Jänner 1992, in: Giersch, H. (Hrsg.), Environmental economics, Heidelberg, Springer-Verl., 1993

9202 SCHNEIDER, Friedrich: The federal and fiscal structures of representative and direct democracies as models for a European federal union: Some preliminary ideas using the public-choice approach, in: Journal des Economistes et des Etudes Humaines, 3. 1993,2

9203 SCHNEIDER, Friedrich: The development of the shadow economy under changing economic conditions: Some tentative empirical results for Austria. Revised version. März 1992.

9204 HACKL, Franz, SCHNEIDER, Friedrich, WITHERS, Glenn: The public sector in Australia: A quantitative analysis. März 1992, in: Gemmell, N. (ed), The growth of the public sector, Aldershot, Elgar, 1993, S. 212-231

9205 SCHNEIDER, Friedrich: The federal and fiscal structures of western democracies as models for a federal union in former communist countries? Some thoughts using the public-choice approach. April 1992, in: Wagner, H.-J. (ed.), On the theory and policy of systematic change, Heidelberg, Springer-Verl., 1993, S. 135-154

9206 WINTER-EBMER, Rudolf: Endogenous growth, human capital, and industry wages. in: Bulletin of Economic Research, 4/1994, 289-314.

9207 BARTEL, Rainer: Gleichgewicht, Ungleichgewicht und Anpassung in der komparativen Statik. August 1992; 1. Teil erschienen unter: Auf welchen Grundlagen beruhen unsere ökonomischen Aussagen? in: Wirtschaft und Gesellschaft, 19, 2, 1993, S. 153-170; 2. Teil erschienen unter: Neoklassische Rationierung, in: WiSt, 23, 3, 1993, S. 151-154

9208 WEISS, Christoph R.: Market structure and pricing behaviour in Austrian manufacturing. August 1992. in: Empirica, 21. 1994, S. 115-131.

9209 WINTER-EBMER, Rudolf: Unemployment and individual pay: Wage curve or compen-sating differentials? erscheint u.d.T.: Wage Curve, Unemployment Duration and Compensating Differentials, in: Labour Economics, 3/1996,4 S. 425-434

9210 SCHUSTER, Helmut: Chaostheorie und Verkehrswissenschaft? September 1992, in: Österreichische Zeitschrift für Verkehrswissenschaft, 1-2, 38. 1992, S. 48-51

9211 BARTEL, Rainer, PRUCKNER, Gerald: Strukturelle und konjunkturelle Charakteristika der Budgetpolitik von Bund und Gesamtstaat in Österreich. Oktober 1992, in: Wirtschaftspolitische Blätter, 40. 1993,2, S. 134-154

9212 PFAFFERMAYR, Michael: Foreign direct investment and exports: A time series approach. Oktober 1992

9213 HACKL, Franz, SCHNEIDER, Friedrich: Austrian economic policy since 1945: An ex-ploratory analysis. Oktober 1992, in: Paldam, M. (ed.), Economic development of small open economies in Europe and South America, Basingstoke, Macmillan, forthcoming 1994

9214 SCHNEIDER, Friedrich: Die Kunst als Wirtschaftsfaktor vernachlässigbar oder beach-tenswert? Oktober 1992, in: Musicologica Austriaca, 11. 1993,1, S. 19-29

9215 SCHNEIDER, Friedrich: Measuring the size and the development of the shadow economy: Can the causes be found and the obstacles be overcome? November 1992, in: Brandstätter, Hermann and Güth, W. (eds.), Essays on Economic Psychology, Heidelberg, Springer-Verl., 1994, S. 208-211

9216 SCHNEIDER, Friedrich: Public choice - economic theory of politics: A survey in selected areas. Dezember 1992, in: Brandstätter, Hermann and Güth, W. (eds.), Essays on 
Economic Psychology, Heidelberg, Springer-Verl., 1994, S. 188-192

9301 SCHUSTER, Helmut: Energiepolitik im Spannungsfeld zwischen Wirtschaft und Umwelt. Jänner 1993, in: Friedrich Schneider (Hrsg.), Energiepolitik in Österreich, Linz, Trauner, 1993

9302 WINTER-EBMER, Rudolf: Motivation to migrate and economic success. März 1993, erscheint u.d.T.: Motivation for Migration and Economic Success, in: Journal of Economic Psychology, 15. 1994, S. 282-284

9303 LANDESMANN, Michael and GOODWIN, Richard: Productivity growth, structural change and macroeconomic stability. März 1993

9304 PFAFFERMAYR, Michael: Foreign outward direct investment and exports in Austrian manufacturing. März 1993

9305 BARTEL, Rainer: Zur Ökonomie der öffentlichen Finanzkontrolle. April 1993, erschienen unter: Öffentliche Finanzkontrolle als politische Machtkontrolle. Eine ökonomische Fundierung, in: Politische Vierteljahresschrift, 34. 1993,4, S. 613-639

9306 HACKL, Franz: Die Internalisierung von überbetrieblichen Leistungen der Landwirtschaft aus allokationstheoretischer Sicht. April 1993.

9307 ZWEIMÜLLER, Josef, WINTER-EBMER, Rudolf, FALKINGER, Josef: Retirement of spouses and social security reform, in: European Economic Review, 40/1996, S. 471-472

9308 BRUNNER, Johann K.: Abilities, needs, and the size of the cake: an axiomatic bargaining approach to redistributive taxation. Juli 1993.

9309 HACKL, Franz, PRUCKNER, Gerald: Touristische Präferenzen für den ländlichen Raum: Die Problematik ihrer empirischen Erfassung und Internalisierung. Juli 1993. Ersch. in: Gesellschaftliche Forderungen an die Landwirtschaft / Gesellschaft für Wirtschafts- und Sozialwissenschaften des Landbaues (GEWISOLA), hrsg. von Konrad Hagedorn ... 1994, Schriften der GEWISOLA, Bd. 30

9310 NECK, Reinhard, SCHNEIDER, Friedrich: Steuersystem und Schattenwirtschaft. Juli 1993.

9311 POINTNER, Johannes und SCHNEIDER, Friedrich: Österreich im internationalen Writschaftssystem, August 1993, in: Ewald Nowotny und Günther Winckler (Hrsg.), Grundzüge der Wirtschaftspolitik Österreichs, 1994.

9312 SCHNEIDER, Friedrich: The Relationship between efficiency and profitability with respect to the size of firms: an empirical investigation for Austria. September 1993.

9313 ÖTSCH, Walter: Die mechanistische Metapher in der Theoriengeschichte der Nationalökonomie. September 1993.

9314 BARTEL, Rainer: Wirtschaftspolitische Kontrolle und Beratung: Grundlagen, Probleme, Erfordernisse. September 1993, erschienen als: Kontrolle und Beratung in der Wirtschaftspolitik, in: Wirtschaftspolitische Blätter, 41. 1994,4, S. 442-462

9315 BARTH, Erling and ZWEIMÜLLER, Josef: Relative wages under decentralized and under corporatist bargaining systems, in: Scandinavian Journal of Economics, 97. 1995,3, S. 369-384

9316 FALKINGER, Josef and ZWEIMÜLLER, Josef: The impact of income inequality on product diversity and economic growth. Oktober 1993.

9317 SCHNEIDER, Friedrich: Anreizorientierte Systeme im Gesundheitswesen unter besonderer Berücksichtigung des stationären Sektors. Oktober 1993.

9318 HORSTMANN, Winfried and SCHNEIDER, Friedrich: Deficits, bailout and free riders: Fiscal elements of European constitution. Oktober 1993.

9319 BARTEL, Rainer: Egoismus, Altruismus, Ineffizienz und Kontrolle im öffentlichen Bereich: Ein kurzer Blick auf die Argumente und ihre Implikationen. November 1993, in: Wirtschaft und Gesellschaft, 20. 1994,2, S. 231-246

9320 BURGER, Christina: Theorien der Koalitionsbildung und ihre Anwendbarkeit auf österreichische Regierungen. November 1993.
9321 BARTEL, Rainer: Konjunkturelle Selbststabiliseriung oder kompensatorische Nachfragepolitik? Ein Leitfaden für Studenten. Dezember 1993, tw. erschienen unter: Konjunkturprobleme - Selbstheilung oder Staatseingriffe?, in: WISO, 17. 1994,4, S. 111-39, erscheint tw. unter: Lohnindexierung Effiziente Institution zur Stabilisierung der Wirtschaft?, in: WiSt, 26. 1997,3, S. 154-156

9401 WINTER-EBMER, Rudolf, ZWEIMÜLLER, Josef: Immigration and the Earnings of Young Native Workers. Jänner 1994, in: Oxford Economic Papers, 48. 1996, S. 473-491

9402 KUNST, Robert, HAUSER, Michael: Fractionally Integrated Models With ARCH Errors. Jänner 1994.

9403 ZWEIMÜLLER, Josef, WINTER-EBMER, Rudolf: Internal Markets and Firm-Specific Determination of Earnings in the Presence of Immigrant Labor, in: Economics Letters, 48. 1995, S. $185-191$

9404 SCHUSTER, Helmut: Energie und Umwelt. März 1994.

9405 PFAFFERMAYR, Michael: Testing for Ownership Advantages of Direct Investing Firms. März 1994.

9406 SCHNEIDER, Friedrich: Determinanten der Steuerhinterziehung und der Schwarzarbeit im internationalen Vergleich. März 1994.

9407 FALKINGER, Josef: Social Stability and the Equity-Efficiency Trade-off. April 1994.

9408 WINTER-EBMER， Rudolf，ZWEIMÜLLER， Josef: Do Immigrants Displace Native Workers? Mai 1994, erscheint in: Journal of Population Economics, 1998.

9409 FALKINGER, Josef: How to overcome free-riding: Rewarding deviations from average. Mai 1994. Revidierte Fassung: Efficient Private Provision of Public Goods by Rewarding Deviations from Average, in: Journal of Public Economics, 62. 1996,3, S. 413-422

9410 ZWEIMÜLLER, Josef: Wealth distribution, innovations, and economic growth. Mai 1994.

9411 GANTNER, Manfried, SCHNEIDER, Friedrich: Budgetausgliederungen - eine polit-ökonomische Analyse. Juni 1994.

9412 AIGINGER, Karl: The use of game theoretical models for empirical research - A survey of testing non-cooperative game theory with real world data in recent industrial organization literature. Juni 1994.

9413 FALKINGER, Josef: The private provision of public goods when the relative size of contribution matters. Juli 1994, in: Finanzarchiv, 51, 1994, S. 358 - 371.

9414 WINTER-EBMER, Rudolf: Sex discrimination and competition in product and labour markets, in: Applied Economics, 27. 1995,9, S. 849-857

9415 FALKINGER, Josef, ZWEIMÜLLER, Josef: The crosscountry Engel curve for product diversification, August 1994, in: Structural Change and Economic Dynamics, 7. 1996,1, S. 79-97

9416 FALKINGER, Josef: Tax evasion, consumption of public goods and fairness, August 1994, in: Journal of Economics Psychology, 16, 1995, S. 63 - 72.

9417 SCHNEIDER, Friedrich: Einige Gedanken zur Harmonisierung indirekter Steuern in der Europäischen Union, September 1994.

9418 WINTER-EBMER, Rudolf: Firm size, earnings and displacement risk, Oktober 1994, erscheint in: Economic Inquiry, 2000.

9419 WEISS, Christoph: Labour market adjustment in U.S. manufacturing: Does market structure matter? Oktober 1994.

9420 WEISS, Christoph: State dependence, symmetry and reversibility of off-farm employment, November 1994.

9421 SCHNEIDER, Friedrich: Is there a European public choice perspective?, Dezember 1994.

9501 BARTEL, Rainer: Reform des öffentlichen Sektors - Grundlagen und Grundsätze, Jänner 1995.

9502 RIESE, Martin: The GINI-index as a measure of the goodness of prediction, Jänner 1995, in: Bulletin of Economic Research, 49. 1997,2 , S. $127-135$ 
9503 AIGINGER, Karl, WINTER-EBMER, Rudolf und ZWEIMÜLLER, Josef: Eastern European Trade and the Austrian Labour Market, in: Weltwirtschaftliches Archiv, 132. 1996,3, S. 476-500

9504 WEISS, Christoph: Size, Growth, and Survival of Upper Austrian Farms in the 1980s, Februar 1995. in: Sotte, F. and Zanoli, R.: "The Regional Dimension of Agricultural Economics and Politics”, forthcoming (1995).

9505 BARTEL, Rainer: Umweltpolitik in den Reformländern Europas. Voraussetzungen und Erfordernisse, Februar 1995.

9506 PFAFFERMAYR, Michael: Foreign Outward Direct Investment and Exports in Austrian Manufacturing: Substitutes or Complements?, March 1995.

9507 BURGER, Christina, SCHNEIDER, Friedrich: How Valuable is the Health of the Elderly- Evaluation of the Treatment of Alzheimer's Disease; April 1995.

9508 BRUNNER, Johann, RIESE, Martin: Measuring the Severity of Unemployment, April 1995.

9509 SCHNEIDER, Friedrich: Volkswirtschaftliche Aspekte der Mitarbeiterbeteiligung, Mai 1995.

9510 ÖTSCH, Walter: Erwartungen und Framing. Keynes und die "Anomalien” der Erwartungsnutzentheorie, Mai 1995.

9511 ÖTSCH, Walter: Die Herausforderung des Konstruktivismus für die ökonomische Theorie, Mai 1995, in: Birger P. Priddat und Gerhard Wegner, Hrsg., Zwischen Evolution und Institution, Metropolis-Verl., Marburg, 1996, S. 35 - 55

9512 ÖTSCH, Walter: Kreativität und Logik im ökonomischen Handlungsmodell, Mai 1995.

9513 WEISS, Christoph: Determinants of Farm Survival and Growth, Mai 1995.

9514 BARTEL, Rainer: Zum Verhältnis von Ökonomie und Politik des öffentlichen Sektors. Einige kurze Anmerkungen, Juni 1995.

9515 KUNST, Robert M.: The Myth of Misspecification. Some Metaphors, Juni 1995

9516 VAN DER BURG, Brigitte, SIEGERS, Jacques, WINTEREBMER, Rudolf: Gender and Promotion in the Academic Labour Market. Juli 1995.

9517 FALKINGER, Josef, FEHR, Emst, GÄCHTER, Simon, WINTER-EBMER, Rudolf: A simple mechanism for the efficient private provision of public goods - experimental evidence, August 1995, erscheint in: American Economic Review, 1999.

9518 SCHNEIDER, Friedrich: Some Elements of a European Federal Union: A Public Choice Approach, September 1995.

9519 BRUNNER, Johann, FALKINGER, Josef: Nonneutrality of taxes and subsidies for the private provision of public goods, September 1995

9520 WEISS, Christoph: Product Market Power and Dynamic Labour Demand, September 1995.

9521 LANDESMANN, Michael, PFAFFERMAYR, Michael: Technological Competition and Trade Performance, October, 1995.

9601 WEISS, Christoph: Exits From a Declining Sector: Econometric Evidence From a Panel of Upper-Austrian Farms 1980-90., Jänner 1996.

9602 BÖS, Dieter und SCHNEIDER, Friedrich: Private-public partnership: Gemeinschaftsunternehmen zwischen Privaten und der öffentlichen Hand, Februar 1996.

9603 GÄCHTER, Simon, FEHR, Emst, KMENT, Christiane: Does Social Exchange Increase Voluntary Cooperation?, Februar 1996.

9604 ZWEIMÜLLER, Josef, BRUNNER, Johann: Heterogeneous consumers, vertical product differentiation and the rate of innovation, März 1996.

9605 SCHNEIDER, Friedrich: The Contributions of Werner W. Pommerehne to Public Choice, März 1996.

9606 SEDJAV, Tsagaan-Uvgun: Wissenschaftlich-technologische Entwicklungsfragen der Mongolei, April 1996, Wissenschaftlicher Betreuer: o.Univ.-Prof. Dr. Helmut Schuster, B.Com.
9607 KEUSCHNIGG, Christian u. KOHLER Wilhelm: Innovation, Capital Accumulation and Economic Transition, revised version April 1996.

9608 AIGINGER, Karl: Beyond Trade Balances: the competitive race between the US, Japan and Europe, Juni 1996.

9609 POMMEREHNE, Werner W., HART, Albert und SCHNEIDER, Friedrich: Tragic Choices and Collective Decision-Making: An Empirical Study of Voter Preferences for Alternative Collective Decision-Making Mechanisms, Juli 1996.

9610 BARTEL, Rainer, POINTNER, Johannes, SCHNEIDER, Friedrich: Österreich im internationalen Wirschaftssystem, Juli 1996, erschienen in: E.Nowotny und G. Winckler (Hg.), Grundzüge der Wirtschaftspolitik Österreichs, 2. Aufl., ManzVerlag, Wien 1997, S. 49-98.

9611 SCHNEIDER, Friedrich, VOLKERT, Jürgen: Die Realisierung ökologisch-orientierter Wirtschaftspolitik - eine Unmöglichkeit? Überlegungen aus Sicht der Neuen Politischen Ökonomie, Juli 1996.

9612 AIGINGER, Karl, WEISS, Christoph R.: Does it Pay to be Flexible? Empirical Evidence on the Relation- ship between Labour Demand Flexibility and Profit Margins, Juli 1996.

9613 WEISS, Christoph R.: Beneficial Concentration in a Menu Cost Model: A Note, August 1996.

9614 GUSENLEITNER, Markus, WINTER-EBMER, Rudolf, ZWEIMÜLLER, Josef: The Distribution of Earnings in Austria, 1972-1991, Allgemeines Statistisches Archiv, 3/98.

9615 WINTER-EBMER, Rudolf:: Benefit Duration and Unemployment Entry: Quasi-Experimental Evidence for Austria, Oktober 1996.

9616 WINTER-EBMER, Rudolf:: Potential Unemployment Benefit Duration and Spell Length: Lessons from a Quasi-Experiment in Austria, in: Oxford Bulletin of Economics and Statistics, 60. 1998,1, S. 33-45

9617 SCHNEIDER, Friedrich, FREY, Bruno S.: Warum wird die Umweltökonomik kaum angewendet?, November 1996.

9618 SCHNEIDER, Friedrich: Aktuelle Ergebnisse über die Schattenwirtschaft (Pfusch) in Österreich, November 1996.

9619 KOHLER, Wilhelm: Die langfristige Entwicklung der Transformationsländer Osteuropas: Welche Rolle spielt die Integration der Märkte?, Dezember 1996.

9620 BRUNNER, Johann K., PRINZ, Christopher, WIRTH, Friedrich: Die Zukunft der gesetzlichen Pensionsversicherung, Dezember 1996.

9621 SCHNEIDER, Friedrich, GAWEL, Erik: Umsetzungsprobleme ökologisch orientierter Steuerpolitik: Eine polit-ökonomische Analyse, Dezember 1996.

9701 SCHNEIDER, Friedrich: Hält der EURO, was er verspricht? Ökonomische Überlegungen zur Stabilität und zur Einführung des EURO, Jänner 1997.

9702 SCHNEIDER, Friedrich: Welche Chancen hat Österreich als Wirtschaftsstandort im EU- und Globalisierungskontext derzeit und in Zukunft?, Jänner 1997.

9703 BRUNNER, Johann K.: Ökonomische Analyse des umlagefinanzierten Pensionsversicherungssystems, Jänner 1997.

9704 PFAFFERMAYR, Michael, WEISS, Christoph R.: On Market Power and Investment Behaviour, January 1997.

9705 LANDESMANN, Michael A., STEHRER, Robert: Industrial Specialisation, Catching-up and Labour Market Dynamics, January 1997.

9706 BARTEL, Rainer: Taking even introductory textbooks seriously. A note on the importance of a usual neglect, February 1997.

9707 KUNST, Robert M.: Decision bounds for data-admissible seasonal models, March 1997.

9708 WINTER-EBMER, Rudolf, ZWEIMÜLLER, Josef: Intra-firm Wage Dispersion and Firm Performance, Kyklos, 1999.

9709 PRITZL, F. J. Rupert und SCHNEIDER, Friedrich: Korruption, März 1997. 
9710 SCHNEIDER, Friedrich: Empirical Results for the Size of the Shadow Economy of Western European Countries Over Time, März 1997.

9711 SCHNEIDER, Friedrich und VOLKERT, Jürgen: No Chance for Incentive-orientated Environmental Policies in Representative Democracies? A Public Choice Approach, März 1997.

9712 FALKINGER, Josef: Wachstum, Verteilung und Beschäftigung, März 1997.

9713 PRITZL, F. J. Rupert und SCHNEIDER, Friedrich: Zur Politischen Ökonomie autokratischer politischer Systeme - Ein theoretischer und empirischer Ansatz, April 1997.

9714 SCHUSTER, Helmut: Das Phänomen der strukturellen Arbeitslosigkeit und Maßnahmen zu seiner Bekämpfung,, Mai 1997.

9715 BARTEL, Rainer: Paradigmatik versus Pragmatik in der (Umwelt-)Ökonomie. Eine epistemologische Sicht, Mai 1997.

9716 BERGER, Helge und SCHNEIDER, Friedrich: Does the Bundesbank Yield in Conflicts? Frey and Schneider Revisited, Juni 1997.

9717 RIESE, Martin und BRUNNER, Johann K.: Interpreting risk with demographic statistics, Juni 1997.

9718 KUNST, Robert M.: Asymptotics for Unit-Root Processes with Underspecified Deterministic Structures, Juni 1997.

9719 GAWEL, Erik und SCHNEIDER, Friedrich: Implementation Problems of Eco-Taxation: A Political-Economy Analysis, Juli 1997

9720 PRITZL, Rupert und SCHNEIDER, Friedrich: Political Economy of Autocratic Political Regimes: A Theoretical and Empirical Approach, Juli 1997

9721 WINTER-EBMER, Rudolf: Unknown Wage Offer Distribution and Job Search Duration, Economics Letters, 1998.

9722 BRUNNER, Johann K.: Optimal Taxation of Income and Bequests, August 1997

9723 KEUSCHNIGG, Christian and KOHLER, Wilhelm: Eastern Enlargement of the EU: How Much is it Worth for Austria?, November 1997

9724 HOFER, Helmut, KEUSCHNIGG, Christian und Wilhelm KOHLER, A Dynamic Applied General Equilibrium Model for the Austrian Economy With Special Emphasis on the Eastern EU Enlargement, November 1997.

9801 WINTER-EBMER, Rudolf und Klaus F. ZIMMERMANN: East-West Trade and Migration: The Austro-German Case, Jänner 1998, erscheint in: Jaime de Melo, Riccardo Faini und Klaus F. Zimmermann (eds.): Trade and Factor Mobility, Cambridge (CUP).

9802 ICHINO, Andrea und Rudolf WINTER-EBMER: The LongRun Educational Cost of World War 2: An Application of Local Average Treatment Effect Estimation, Jänner 1998.

9803 SCHNEIDER, Friedrich: Deregulierung und Privatisierung als Allheilmittel gegen ineffiziente Produktion von öffentlichen Unternehmen? Ein Erklärungsversuch mit Hilfe der ökonomischen Theorie der Politik, Jänner 1998.

9804 SCHNEIDER, Friedrich: Märkte, Moral und Umwelt: Was sagt die Ökonomie dazu?, Jänner 1998.

9805 LENK, Thomas, FUGE, Heidi und SCHNEIDER, Friedrich: Zurück zu mehr Föderalismus: Ein Vorschlag zur Neugestaltung des Finanzausgleichs in der BRD unter besonderer Berücksichtigung der ökonomischen Theorie der Politik, Jänner 1998.

9806 SCHNEIDER, Friedrich: Stellt das starke Anwachsen der Schwarzarbeit eine wirtschaftspolitische Herausforderung dar? Einige Gedanken aus volkswirtschaftlicher Sicht, Jänner 1998.

9807 SCHNEIDER, Friedrich: Einige grundlegende Elemente einer europäisch-föderalen Verfassung unter Zuhilfenahme der konstitutionellen ökonomischen Theorie, Jänner 1998.

9808 LANDESMANN, Michael: Vertical produkt differentiation and international trade: an econometric analysis, März 1998.

9808a BARTEL, Rainer: Öffentliche Finanzen, Finanzkontrolle und gesellschaftliche Wohlfarht. Volkwirtschaftliche Thesen, Antithesen und mögliche Synthesen, März 1998. Erschienen in überarbeiteter Version in: F. Klug (Hrsg.), Wesen und staatspolitische Funktion der öffentlichen Finanzkontrolle, Schriftenreihe des Instituts für Kommunalwissenschaften an der Universität Linz, Bd. 107, S. 85-127.

9809 AIGINGER, Karl und PFAFFERMAYR, Michael:

Product quality, cost asymmetry and the welfare loss of oligopoly, Februar 1998.

9810 KOHLER, Wilhelm: Die Ost-Erweiterung der EU: Eine österreichische Perspektive, April 1998.

9811 BERGER, Mathias und SCHNEIDER, Friedrich: Schattenwirtschaft und Steuerhinterziehung: Ökonomische und psychologische Aspekte, April 1998.

9812 SCHNEIDER, Friedrich und STIEGLER, Harald: Controlling als effizienzsteigerndes Instrument der Universitätsführung Zauber- oder Leerformel?, April 1998.

9813 KUNST, Robert M.: Some aspects of modeling seasonality in economic time series, Juni 1998.

9814 KOHLER, Wilhelm: Fifty Years Later: A New Marshall Plan for Eastern Europe?, Juli 1998.

9815 RAPHAEL, Steven und WINTER-EBMER, Rudolf: Identifying the Effect of Unemployment on Crime, September 1998.

9816 ICHINO, Andrea und WINTER-EBMER, Rudolf: Lower and Upper Bounds of Returns to Schooling: An Exercise in IV Estimation with Different Instruments, September 1998, erscheint in: European Economic Review, 1999.

9817 PÖLL, Günther und SCHNEIDER, Friedrich: Schattenwirtschaft, Juli 1998.

9818 BRUNNER, Johann K.: Kapitaldeckungsverfahren versus Umlageverfahren: Grundsätzliches zur Systemdiskussion, August 1998.

9819 SCHNEIDER, Friedrich und ENSTE, Dominik: Increasing Shadow Economies all over the world - Fiction or Reality? A Survey of the Global Evidence of its Size and of its Impact from 1970 to 1995 , November 1998.

9820 LENK, Thomas und SCHNEIDER, Friedrich: Zurück zu mehr Föderalismus: Ein Vorschlag zur Neugestaltung des Finanzausgleichs in der Bundesrepublik Deutschland unter besonderer Berücksichtigung der neuen Bundesländer, November 1998

9821 KOHLER, Wilhelm: Die Bedeutung der EU-Osterweiterung für verschiedene Sektoren der österreichichen Wirtschaft, November 1998.

9822 KOHLER, Wilhelm: Die pan-europäische Integration: Herausforderungen für die Wirtschaftswissenschaft, November 1998.

9823 ATKINSON, Anthony B.: The Changing Distribution of Income: Evidence and Explanations (1. K.W. Rothschild Vorlesung), November 1998.

9824 PECH, Susanne und PFAFFERMAYR, Michael: Strategic Environmental Taxation in the Presence of Involuntary Unemployment and Endogenous Location Choice, November 1998.

9825 BARTEL, Rainer: Reform und Öffnung Osteuropas, November 1998.

9826 ÖTSCH, Walter: Zur Geschichte und Zukunft von Grundkategorien des ökonomischen Denkens: Raum, Zeit, Objekt und Ich, November 1998.

9827 ÖTSCH, Walter: „Äußere“ und „Innere“ Glücksmodelle in der Theoriegeschichte der Ökonomie, November 1998, erscheint in: Zinn, Bellebaum und Schaaf: Ökonomie und Glück, Frühjahr 1999.

9828 ÖTSCH, Walter: Konstruktivismus und ökonomische Theorie, November 1999, erscheint in: Lehmann und Pillath: Handbuch der Evolutorischen Ökonomik, Springer Verlag, 1999.

9901 WINTER-EBMER, Rudolf and ZWEIMÜLLER, Josef: Firm Size Wage Differentials in Switzerland: Evidence from Job Changers, Jänner 1999, erscheint in: American Economic Review, Papers \& Proceedings, 1999. 
9902 BRANDSTÄTTER, Eduard, KÜHBERGER, Anton und SCHNEIDER, Friedrich: "Surprise in Decision making under Uncertainty, Jänner 1999.

9903 SCHNEIDER, Friedrich und WAGNER, Alexander: "The Role of International Monetary Institutions after the EMU and after the Asian Crises: Some Preliminary Ideas Using Constitutional Economics", Februar 1999

9904 BRUNNER, Johann K.: Transfers zwischen den Generationen, Februar 1999.

9905 LACKÓ, Mária: Hidden Economy - An Unknown Quantity? Comparative Analysis of Hidden Economies in Transition Countries in 1989-1995, Februar 1999

9906 KOHLER, Wilhelm: Trade and Wages: What Can Factor Contents Tell Us? Februar 1999.

9907 LANDESMANN, Michael und STEHRER Robert: The European Unemployment Problem: A Structural Approach, März 1999.

9908 SCHNEIDER, Friedrich: Das Verhältnis von Innovation und Beschäftigung aus wirtschaftlicher Sicht - Jobkiller oder Jobwunder?, Mai 1999.

9909 SCHNEIDER, Friedrich und LENK, Thomas: Zurück zum Trennsystem als Königsweg zu mehr Föderalismus in Zeiten des „Aufbau Ost“, Juni 1999.

9910 SCHNEIDER, Friedrich: Die Entwicklung der Sozialpolitik in repräsentativen und in direkten Demokratien: Königsweg oder Sackgasse? Einige Bemerkungen aus der „Public Choice“Perspektive, Juni 1999.

9911 SCHNEIDER, Friedrich: Ist Schwarzarbeit ein Volkssport geworden? Ein internationaler Vergleich des Ausmaßes der Schwarzarbeit von 1970 bis 1997, Juni 1999.

9912 FELBERMAYR, Gabriel, und KOHLER, Wilhelm: Zur ökonomischen Logik spekulativer Attacken, Juli 1999.

9913 FERSTERER, Josef und WINTER-EBMER, Rudolf: Returns to Education - Evidence for Austria, August 1999.

9914 BARTEL, Rainer: Social economic issues in sexual orientation - Where do we stand?, September 1999.

9915 SCHNEIDER, Friedrich und ENSTE, Dominik: Shadow Economies: Sizes, Causes, and Consequences, September 1999.

9916 BARTEL, Rainer: Ökonomische Rationalität im System de öffentlichen Finanzkontrolle. Die Funktionalität des neuen Oö. Landesrechnungshofs. September 1999.

9917 FERSTERER, Josef und Rudolf WINTER-EBMER: Are Austrian Returns to Education Falling Over Time?, Oktober 1999.

9918 SCHNEIDER, Friedrich und WINNER, Hannes: Ein Vorschlag zur Reform der österreichischen Unternehmensbesteuerung, November 1999.

9919 SCHNEIDER, Friedrich: Induzieren ökologische Steuerreformen einen Lenkungseffekt oder nur volle Staatskassen? Einige volkswirtschaftliche Überlegungen, November 1999.

9920 KOHLER, Wilhelm: Wer gewinnt, wer verliert durch die Osterweiterung der EU?, November 1999.

9921 DRÈZE, Jacques: On the Macroeconomics of Uncertainty and Incomplete Markets, November 1999.

9922 STIGLBAUER, Alfred M. und WEISS, Christoph R.: Family and Non-Family Succession in the Upper-Austrian Farm Sector, Dezember 1999.

9923 HOLZLEITNER, Christian: Linear Profit-Sharing in Regulatory Contracts, Dezember 1999.

9924 ÖTSCH, Walter: Objekt, Subjekt und Wert. Zur Kulturgeschichte in Georg Simmels "Philosophie des Geldes", Dezember 1999.

0001 KOHLER, Wilhelm: Die Osterweiterung der EU aus der Sicht bestehender Mitgliedsländer: Was lehrt uns die Theorie der ökonomischen Integration?, Jänner 2000.

0002 FERSTERER, Josef und WINTER-EBMER, Rudolf: Smoking, Discount Rates, and Returns to Education, Jänner 2000 .
0003 BARTEL, Rainer: Quo vadimus. Grundgedanken zum Verhältnis von Wirtschaft, Staat und Gesellschaft, Februar 2000.

0004 SCHNEIDER, Friedrich und FREY, Bruno S.: Informal and Underground Economy, Februar 2000.

0005 SCHNEIDER, Friedrich und FELD, Lars P.: State and Local Taxation, Februar 2000.

0006 ZWEIMÜLLER, Josef und WINTER-EBMER, Rudolf: Firmspecific Training - Consequences for Job Mobility, März 2000.

0007 SCHNEIDER, Friedrich: Schattenwirtschaft - Tatbestand, Ursachen, Auswirkungen, April 2000

0008 SCHNEIDER, Friedrich: The Increase of the Size of the Shadow Economy of 18 OECD Countries: Some Preliminary Explanations, April 2000

0009 SCHNEIDER, Friedrich und AHLHEIM, Michael: Allowing for Household Preferences in Emission Trading - A Contribution to the Climate Policy Debate, Mai 2000

0010 SCHNEIDER, Friedrich: Illegal Activities, but still value added ones (?): Size, Causes, and Measurement of the Shadow Economies all over the World, Mai 2000.

0011 WEICHSELBAUMER, Doris: Is it Sex or Personality? The Impact of Sex-Stereotypes on Discrimination in Applicant Selection, Mai 2000.

0012 FELBERMAYR, Gabriel, und KOHLER, Wilhelm: Effizienzund Verteilungswirkungen der Handelsliberalisierung, Juni 2000.

0013 EGGER, Peter und PFAFFERMAYR, Michael: Trade, Multinational Sales, and FDI in a Three-Factors Model, Juni 2000 .

0014 LANDESMANN, Michael und STEHRER, Robert: Potential Switchovers in Comparative Advantage: Patterns of Industrial Convergence, Juni 2000.

0015 SCHNEIDER, Friedrich und WAGNER, Alexander: Korporatismus im europäischen Vergleich: Förderung makroökonomischer Rahmenbedingungen?, Juli 2000.

0016 SCHNEIDER, Friedrich und LENK, Thomas: Grundzüge der föderalen Finanzverfassung aus ökonomischer Perspektive: Trennsystem vs. Verbundsystem, Juli 2000.

0017 HOLZLEITNER, Christian: Efficient Cost Passthrough, August 2000.

0018 HOLZLEITNER, Christian: Evolution of Regulatory Contracts in the Real World - A Change for Good?, August 2000.

0019 KOHLER, Wilhelm: International Fragmentation: A Policy Perspective, August 2000.

0020 KOHLER, Wilhelm: A Specific-Factors View on Outsourcing, August 2000.

0021 WEICHSELBAUMER, Doris: Sexual Orientation Discrimination in Hiring, September 2000.

0022 KOHLER; Wilhelm: Internationale Migration: Anmerkungen aus der Sicht der Außenwirtschaftstheorie, Oktober 2000.

0023 AIGINGER, Karl und DAVIES, S.W.: Industrial Specialisation and geographic Concentration: Two sides of the same coin? Not for the European Union, Oktober 2000.

0024 EGGER, Hartmut und EGGER, Peter: Outsourcing and SkillSpecific Employment in a Small Economy: Austria and the Fall of the Iron Curtain, Oktober 2000.

0025 KOHLER, Wilhelm: An Incumbent Country View on Eastern Enlargement of the EU - Part I: A Gerneral Treatment, November 2000.

0026 KOHLER, Wilhelm: An Incumbent Country View on Eastern Enlargement of the EU - Part II: The Austrian Case, November 2000.

0027 FREY, Bruno S.: What are the sources of happiness?, November 2000

0028 RIESE, Martin: Weakening the SALANT-condition for the Comparison of mean durations, Dezember 2000

0029 WINTER-EBMER, Rudolf: Long-term consequences of an innovative redundancy-retraining project: The Austrian Steel Foundation, Dezember 2000.

0030 BRUNNER, Johann K. und PECH, Susanne: Adverse Selection in the annuity market when payoffs vary over the time of retirement, Dezember 2000. 
0101 KOHLER, Wilhelm: Osterweiterung der EU: Die Mitgliedschaft wird teurer - Wird sie auch wertvoller?, Jänner 2001.

0102 STEHRER, Robert: Industrial specialisation, trade, and labour market dynamics in a multisectoral model of technological progress, Jänner 2001.

0103 SCHNEIDER, Friedrich; SALHOFER, Klaus; SCHMID, Erwin, und STREICHER, Gerhard: Was the Austrian Agricultural Policy Least Cost Efficient?, März 2001.

0104 SCHNEIDER, Friedrich; KIRCHLER, Erich und MACIEJOVSKY, Boris: Social Representations on Tax Avoidance, Tax Evasion, and Tax Flight: Do Legal Differences Matter?, März 2001.

0105 SCHNEIDER, Friedrich; PITLIK, Hans, und STROTMANN, Harald: On the Politicization of Intergovernmental Fiscal Relations in Germany after Unification, März 2001.

0106 SCHNEIDER, Friedrich: Privatisierung und Deregulierung in Österreich in den 90er Jahren: Einige Anmerkungen aus Sicht der Neuen Politischen Ökonomie, März 2001.

0107 SCHNEIDER, Friedrich; BRAITHWAITE, Valerie, and REINHART, Monika: Individual Behavior in the Cash / Shadow Economy in Australia: Facts, Empirical Findings and some Mysteries, März 2001.

0108 BRUNELLO, Giorgio; LUCIFORA, Claudio, und WINTEREBMER, Rudolf: The Wage Expectations of European College Students, März 2001.

0109 BRUNNER, Johann K. und PECH, Susanne: Die Dritte Säule der Altersvorsorge - Sparen und Versichern?, Juni 2001.

0110 STÖGER, Klaus und WINTER-EBMER, Rudolf: Lehrlingsausbildung in Österreich: Welche Betriebe bilden Lehrlinge aus? Juli 2001.

0111 HEIJDRA, Ben J.; KEUSCHNIGG, Christian, und KOHLER, Wilhelm: Eastern Enlargement of the EU: Jobs, Investment and Welfare in Present Member Countries, Oktober 2001

0112 BRUNNER, Johann und BUCHEGGER, Reiner: Gesundheitsgüter und Gesundheitsdienstleistungen in Österreich, Dezember 2001.

0113 MALINVAUD, Edmond: On methodolgy in macroeconomics - with application to the demand for unskilled labour, November 2001.

$$
* * *
$$

0201 KOHLER, Wilhelm: The Distributional Effects of International Fragmentation, April 2002.

0202 WINTER-EBMER, Rudolf and WIRZ, Aniela: Public Funding and Enrolment into Higher Education in Europe, April 2002.

0203 KOHLER, Wilhelm: Issues of US-EU Trade Policy, May 2002

0204 BRUNNER, Johann K. und PECH, Susanne: Adverse selection in the annuity market with sequential and simultaneous insurance demand, May 2002.

0205 Stiglbauer, Alfred, Stahl, Florian, Winter-Ebmer, Rudolf and Josef Zweimüller: Job Creation and Job Destruction in a Regulated Labor Market: The Case of Austria, July 2002.

0206 BÖHEIM, René und TAYLOR, Mark P: Job search methods, intensity and success in Britain in the 1990s, July 2002.

0207 BURGSTALLER, Johann: Are stock returns a leading indicator for real macroeconomic developments?, July 2002.

0208 KOHLER, Wilhelm: Aspects of International Fragmentation, August 2002.

0209 PECH Susanne: Tax incentives for private life annuities and the social security reform: effects on consumption and on adverse selection, August 2002.

0210 BRUNELLO, Giorgio and WINTER-EBMER, Rudolf: Why Do Students Expect to Stay Longer in College? Evidence from Europe, August 2002.

0211 RIESE, Martin: A New Class of Ageing Distributions, December 2002.

0212 BRUNNER, Johann K.: Welfare Effects of Pension Finance Reform, December 2002.
0301 SCHNEIDER, Friedrich and BAJADA, Christopher: The Size and Development of the Shadow Economies in the Asia-Pacific, April 2003.

0302 SCHNEIDER, Friedrich, CHAUDHURI, Kausik and CHATTERJEE, Sumana: The Size and Development of the Indian Shadow Economy and a Comparison with other 18 Asian Countries: An Empirical Investigation, April 2003.

0303 SCHNEIDER, Friedrich, WAGNER, Alexander F. and DUFOUR, Mathias: Satisfaction not guaranteed - Institutions and sastisfaction with democracy in Western Europe, April 2003.

0304 SCHNEIDER, Friedrich and WAGNER; Alexander, F.: Tradeable permits - Ten key design issues, April 2003.

0305 KOHLER, Wilhelm: Factor Price Frontiers with International Fragmentation of Multistage Production, April 2003.

0306 BURGSTALLER, Johann: Interest Rate Transmission to Commercial Credit Rates in Austria, May 2003.

0307 WEICHSELBAUMER, Doris and WINTER-EBMER, Rudolf: The effects of competition and equal treatment laws on the gender wage differential, July 2003.

0308 MAYR, Karin: Immigration and Majority Voting on Income Redistribution - Is there a Case for Opposition from Natives?, July 2003.

0309 BRUNNER, Johann K.: Optimum taxation of income from labour and capital in a dynamic two-person economy, September 2003.

0310 BRUNNER, Johann K.: Optimale direkte und indirekte Steuern bei unterschiedlicher Anfangsausstattung, September 2003.

0311 WEICHSELBAUMER, Doris and WINTER-EBMER, Rudolf: A meta-analysis of the international gender wage gap, September 2003.

0312 WEICHSELBAUMER, Dors and WINTER-EBMER, Rudolf: Rhetoric in Economic Research: The Case of Gender Wage Differentials, September 2003.

0313 DULLECK, Uwe, FRIJTERS, Paul and WINTER-EBMER, Rudolf: Reducing Start-up costs for New Firms. The Double Dividend on the Labor Market, October 2003.

0314 Aiginger, Karl: Insufficient investment into future growth: the forgotten cause of low growth in Germany, November 2003

0315 FELBERMAYR, Gabriel J. and LICANDRO, Omar: The underestimated virtues of the two-sector AK model, December 2003.

0316 KOHLER, Wilhelm: Eastern Enlargement of the EU: A Comprehensive Welfare Assessment, December 2003.

0317 RODRIK, Dani: Growth Strategies, December 2003.

0401 FELBERMAYR, Gabriel and KOHLER, Wilhelm: Immigration and Native Welfare, February 2004.

0402 FELBERMAYR, Gabriel: Specialization on a Technologically Stagnant Sector Need Not Be Bad for Growth, March 2004.

0403 SCHNEIDER, Friedrich and KLINGLMAIR, Robert: Shadow Economies around the World: What do we know?, April 2004.

0404 BELKE, Ansgar and SCHNEIDER, Friedrich: Privatization in Austria: Some Theoretical Reasons and Performance Measures, June 2004.

0405 SCHNEIDER, Friedrich and BURGER, Christina: Formal and Informal Labour Markets: Challenges and Policy in the Central and Eastern European new EU Members and Candidate Countries, June 2004.

0406 SCHOR, Juliet: Sustainable Consumption and Worktime Reduction, June 2004.

0407 FELBERMAYR, Gabriel: Does Trade Cause Divergence? Dynamic Panel Data Evidence, Juni 2004.

0408 BUCHEGGER, Reiner and WÜGER Michael: Private Expenditures for Children in Austria - Variations in Results applying different Models, July 2004.

0409 MAYR, Karin: The Fiscal Impact of Immigrants in Austria - A Generational Accounting Analysis, July 2004. 
0410 HALLA, Martin: Unterhalt, Obsorge und Scheidungsanwälte: Eine ökonometrische Untersuchung der einvernehmlichen Scheidung in Österreich., August 2004.

0411 RAFERZEDER, Thomas and WINTER-EBMER Rudolf: Who is on the Rise in Austria: Wage Mobility and Mobility Risk, September 2004.

0412 PECH, Susanne: Adverse Selection with individual- and jointlife annuities, November 2004

0413 LICHTENECKER, Ruperta: Gender Budget Analyse: Akademische Übung oder politische Relevanz?, December 2004.

0414 PECH, Susanne: Portfolio decisions on life annuities and financial assets with longevity and income uncertainty, December 2004.

0415 HACKL, Franz, HALLA, Martin and PRUCKNER, Gerald, J.: The Fallacy of the Good Samaritan: Volunteering as a Weird Way of Making Money, December 2004.

0501 BUCHEGGER, Reiner and RIEDL, René: Asymmetric Information as a Cause for Market Failure - Application Service Providing (ASP) in Austria, January 2005.

0502 SCHNEEWEIS, Nicole and WINTER-EBMER, Rudolf: Peer Effects in Austrian Schools, March 2005.

0503 BURGSTALLER, Johann: When and why do Austrian companies issue shares?, April 2005.

0504 BÖHEIM, René, STIGLBAUER, Alfred and WINTEREBMER, Rudolf: When and how to create a job: The survival of new jobs in Austrian firms, May 2005.

0505 HALLA, Martin, SCHNEIDER, Friedrich: Taxes and Benefits: Two Distinct Options to Cheat on the State?, August 2005

0506 BRUNNER, Johann and PECH, Susanne: Optimum Taxation of Life Annuities, November 2005.

0507 SCHUSTER, Helmut: Reduktionismus, interaktionistischer Eigenschafts-Dualismus und Epiphänomenalismus, Dezember 2005.

0508 DULLECK, Uwe and KERSCHBAMER, Rudolf: Price Discrimination via the Choice of Distribution Channels, December 2005

0509 DULLECK, Uwe and KERSCHBAMER, Rudolf: Experts vs. Discounters: Consumer Free Riding and Experts Withholding Advice in Markets for Credence Goods, December 2005.

0510 BURGSTALLER, Johann: Interest rate pass-through estimates from vector autoregressive models, December 2005.

0511 HACKL Franz, HALLA Martin and PRUCKNER, Gerald, J.: Coasian Payments for Agricultural External Benefits - An Empirical Cross Section Analysis, December 2005.

0512 BÖHEIM René and MAYR, Karin: Immigration and Public Spending, December 2005.

0601 LICHTENECKER, Ruperta: UmwelttechnikindustrieZukunftsmarkt China, Jänner 2006

0602 BURGSTALLER, Johann: The cyclicality of interest rate spreads in Austria: Evidence for a financial decelerator?, July 2006.

0603 DREHER, Axel and SCHNEIDER, Friedrich: Corruption and the Shadow Economy: An Empirical Analysis, July 2006.

0604 SAVASAN, Fatih and SCHNEIDER, Friedrich: What Determines Informal Hiring? Evidence from the Turkish Textile Sector, July 2006.

0605 SCHNEIDER, Friedrich, SOOKRAM Sandra and WATSON, Patrick Kent: Characteristics of the Household Sector of the Hidden Economy in an Emerging Economy, July 2006.

0606 BELKE, Ansgar, BAUMGÄRTNER, Frank, SETZER, Ralph and SCHNEIDER, Friedrich: The Different Extent of Privatisation Proceeds in EU Countries: A Preliminary Explanation Using a Public Choice Approach, July 2006.
0607 DELL'ANNO, Roberto and SCHNEIDER, Friedrich: Estimating the Underground Economy by Using MIMIC Models: A Response to T. Breusch's critique, July 2006.

0608 SCHNEIDER, Friedrich and TORGLER, Benno: What Shapes Attitudes Toward Paying Taxes? Evidence from Multicultural European Countries, July 2006.

0609 DREHER Axel, MÉON, Pierre-Guillaume, SCHNEIDER, Friedrich and WEILL, Laurent: Does the shadow economy raise observed aggregate efficiency? A cross-country comparison, July 2006.

0610 PROHL, Silika and SCHNEIDER, Friedrich, Sustainability of Public Debt and Budget Deficit: Panel cointegration analysis for the European Union Member countries, July 2006.

0611 BURGSTALLER, Johann: Bank income and profits over the business and interest rate cycle, July 2006.

0612 BÖHEIM, René and WEBER, Karin: The effects of marginal employment on subsequent labour market outcomes, July 2006.

0613 DULLECK, Uwe, FRIJTERS, Paul and PODCZECK, Konrad: All-pay Auctions with Budget Constraints and Fair Insurance, July 2006.

0614 GLÄSER, Lars and HALLA, Martin Die EU-Zinsenrichtlinie: Ein Schuss in den Ofen?, August 2006.

0615 ÖTSCH, Walter: Gottes-Bilder und ökonomische Theorie: Naturtheologie und Moralität bei Adam Smith, August 2006.

0616 BURGSTALLER, Johann: Financial Predictors of Real Activity and the Propagation of Aggregate Shocks, September 2006.

0617 SCHNEIDER, Friedrich: Shadow Economies and Corruption all over the World: What do we really know?, September 2006. 